\title{
PUBLIC FINANCIAL MANAGEMENT
}

SYSTEMS-INDONESIA KEY ELEMENTS FROM A FINANCIAL MANAGEMENT PERSPECTIVE 
PUBLIC FINANCIAL

MANAGEMENT

SYSTEMS-INDONESIA

KEY ELEMENTS FROM A FINANCIAL

MANAGEMENT PERSPECTIVE

MAY 2018 
(C) 2018 Asian Development Bank

6 ADB Avenue, Mandaluyong City, 1550 Metro Manila, Philippines

Tel +632 632 4444; Fax +6326362444

www.adb.org

Some rights reserved. Published in 2018.

ISBN 978-92-9261-162-0 (print), 978-92-9261-163-7 (electronic)

Publication Stock No. TCS189338-2

DOI: http://dx.doi.org/10.22617/TCS189338-2

The views expressed in this publication are those of the authors and do not necessarily reflect the views and policies of the Asian Development Bank (ADB) or its Board of Governors or the governments they represent.

ADB does not guarantee the accuracy of the data included in this publication and accepts no responsibility for any consequence of their use. The mention of specific companies or products of manufacturers does not imply that they are endorsed or recommended by $\mathrm{ADB}$ in preference to others of a similar nature that are not mentioned.

By making any designation of or reference to a particular territory or geographic area, or by using the term "country" in this document, $A D B$ does not intend to make any judgments as to the legal or other status of any territory or area.

This work is available under the Creative Commons Attribution 3.0 IGO license (CC BY 3.0 IGO)

https://creativecommons.org/licenses/by/3.0/igo/. By using the content of this publication, you agree to be bound by the terms of this license. For attribution, translations, adaptations, and permissions, please read the provisions and terms of use at https://www.adb.org/terms-use\#openaccess.

This CC license does not apply to non-ADB copyright materials in this publication. If the material is attributed to another source, please contact the copyright owner or publisher of that source for permission to reproduce it. $\mathrm{ADB}$ cannot be held liable for any claims that arise as a result of your use of the material.

Please contact pubsmarketing@adb.org if you have questions or comments with respect to content, or if you wish to obtain copyright permission for your intended use that does not fall within these terms, or for permission to use the ADB logo.

Notes:

In this publication, " $\$$ ” refers to US dollars.

Corrigenda to ADB publications may be found at http://www.adb.org/publications/corrigenda. 


\section{Contents}

Tables, Figures, and Boxes

Acknowledgments

vii

Abbreviations

ix

$\begin{array}{ll}\text { I. Introduction } & 1\end{array}$

II. Key Players 2

A. Ministry of Finance 2

B. Audit Board of the Republic of Indonesia 6

C. Financial and Development Supervisory Board 6

D. National Development Planning Agency 6

E. Ministry of Home Affairs $\quad 7$

F. Bank Indonesia $\quad 7$

G. Asian Development Bank $\quad 7$

III. Budgeting 9

A. Project Financing Mechanism 9

B. State General Treasury Account $\quad 13$

C. Budget Recording and Reporting 14

D. Budget Process 16

E. Budgetary Channels 25

F. Internal Controls 28

$\begin{array}{ll}\text { IV. Onlending Arrangements } & 31\end{array}$

$\begin{array}{ll}\text { A. For Ministries and Agencies } & 32 \\ \text { B. For Subnational Governments } & 32 \\ \text { C. For State-Owned Enterprises } & 32\end{array}$

V. Foreign Exchange and Interest Rate Risks 33

VI. Funds Flow Arrangements $\quad 34$

A. Advance Fund Procedure $\quad 34$

B. Direct Payment Procedure $\quad 37$

C. Commitment Procedure 39

D. Reimbursement Procedure 42 
VII. Accounting and Reporting

A. Accounting Standards $\quad 45$

B. Financial Regulations $\quad 47$

C. Application of Accounting Standards and Regulations $\quad 52$

D. Accounting System $\quad 52$

E. Responsible Units $\quad 55$

F. Fiscal Year 56

G. Project Financial Statements $\quad 56$

$\begin{array}{ll}\text { VIII. Auditing Arrangements } & 58\end{array}$

A. Auditing Requirements $\quad 59$

B. Resolution of Problems Raised in External Audit Reports 62

IX. Summary of Risks and Issues, and Proposed Mitigating Actions and Improvements

\section{Appendixes}

1 Agreed Standard Terms of Reference for the Audit of ADB Projects 66

2 Useful References and Suggested Readings $\quad 79$ 


\section{Tables, Figures, and Boxes}

\section{Tables}

$1 \quad$ Regional Budget Calendar 25

2 Implementation of Accrual-Based Accounting Standards 50

3 Common Issues, Problems, and Suggestions for Mitigating 64

\section{Figures}

1 Project Cycle 9

2 Steps in Planning $\quad 12$

3 Project Loan Processing System 14

4 Timeline for the Adoption of Accrual-Based Accounting Standards $\quad 15$

5 Transition to Accrual Accounting 16

6 Government Affairs 17

7 Central Government Budget Cycle 18

8 Changes in the Structure of Fund Transfers to Regions and Villages,

9 Fund Allocation from Central to Local Government 24

10 Budget Provision for Foreign-Funded Projects 26

11 Onlending and Subgranting of Foreign Funds 31

12 Advance Fund Procedure $\quad 35$

13 Direct Payment Procedure 38

14 Commitment Procedure 40

15 Reimbursement Procedure 43

16 Conceptual Framework of Government Accounting 48

Comparison of IPSAS and Accrual-Based Indonesian Government
Accounting Standards

\section{Boxes}

1 Documents Required for Funds Disbursement under Advance Fund Procedure

2 Documents Required for Funds Disbursement under Direct Payment Method $\quad 39$

3 Documents Required for Issuance of Commitment Letter 42

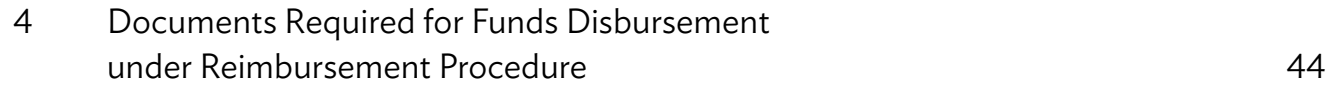

5 Source Documents of Expenditure $\quad 54$ 


\section{Acknowledgments}

$T_{\text {Prosen }}^{\text {he }}$

he project team-Aman Trana, director, public financial management division,

Procurement, Portfolio and Financial Management Department (PPFD), Asian

Development Bank (ADB); Srinivasan Janardanam, principal financial management specialist; Anouj Mehta, principal financial management specialist; Akmal Nartayev, senior financial management specialist; Mocktar Adamou-Ndiaye, financial management specialist; Myra Ravelo, senior financial management officer, PPFD; and former staff Abbas Kizilbash and Jessana Yanuario-would like to thank the following government officials who met with Nishan Mendis (consultant) and made valuable contributions to this report:

\section{Directorate General of Budget Financing and Risk Management}

Ayu Sukorini, director for loans and grants

Widjanarko Soebadhi, director for evaluation, accounting, and settlement

\section{Directorate General of Treasury}

Rudy Widodo, director of state cash management

Firmansyah N. Nazaroedin, director of accounting and financial reporting

Ari Wahyuni, director of system management invesment

\section{Directorate General of Budget Financing and Risk Management}

Agung Widiadi, director of budget systems

\section{Directorate General of Fiscal Balance}

Ahmad Yani, director of funding and regional capacity

\section{Audit Board of the Republic of Indonesia (BPK)}

Hendar Ristiawan, secretary general

\section{Financial and Development Supervisory Board (BPKP)}

Salamat Simanullang, director of audit of foreign loans and grants

\section{Ministry of Home Affairs}

Indro Baskoro, secretary of the Directorate General of Regional Financial Administration

\section{National Development Planning Agency (BAPPENAS)}

Tuti Riyati, director of planning and development funding 


\section{Polytechnic Education Development Project}

Illah Sailah, project director

Kokok Haksono, manager

Coral Reef Rehabilitation and Management Program-Coral Triangle Initiative Project

Sri Atmini, secretary of the Directorate General of Marine, Coastal, and Small Islands Miftahul Huda, project coordinator.

The project team is likewise grateful for the assistance of the following ADB staff at the Indonesia Resident Mission: Linarti Reksoatmodjo, senior financial control officer; Barlev Nicodemus Hutagalung, programs officer; Fitrina Muchtar, financial control analyst; and former staff H. S. Soewartono. 


\section{Abbreviations}

\begin{tabular}{|c|c|c|}
\hline$A D B$ & - & Asian Development Bank \\
\hline AFS & - & Aplikasi Forecasting Satker (Work-Units Forecasting Application) \\
\hline APBD & - & $\begin{array}{l}\text { Anggaran Pendapatan dan Belanja Daerah } \\
\text { (regional revenue and expenditure budget) }\end{array}$ \\
\hline APBN & - & Anggaran Pendapatan dan Belanja Negara (state budget) \\
\hline BAPEPAM-LK & - & $\begin{array}{l}\text { Badan Pengawas Pasar Modal dan Lembaga Keuangan (Capital } \\
\text { Markets and Financial Institutions Supervisory Board) }\end{array}$ \\
\hline BAPPENAS & - & $\begin{array}{l}\text { Badan Perencanaan Pembangunan Nasional } \\
\text { (National Development Planning Agency) }\end{array}$ \\
\hline BKF & - & Badan Kebijakan Fiskal (Fiscal Policy Agency) \\
\hline BPK & - & $\begin{array}{l}\text { Badan Pemeriksa Keuangan } \\
\text { (Audit Board of the Republic of Indonesia) }\end{array}$ \\
\hline BPKP & - & $\begin{array}{l}\text { Badan Pengawasan Keuangan dan Pembangunan } \\
\text { (Financial and Development Supervisory Board) }\end{array}$ \\
\hline CTLA & - & $\begin{array}{l}\text { Loan Administration Division of the Controller's Department } \\
\text { of ADB }\end{array}$ \\
\hline DAK & - & Dana Alokasi Khusus (Special Allocation Fund) \\
\hline DAU & - & Dana Alokasi Umum (General Allocation Fund) \\
\hline $\mathrm{DBH}$ & - & Dana Bagi Hasil (Revenue-Sharing Fund) \\
\hline DIPA & - & $\begin{array}{l}\text { Daftar Isian Pelaksanaan Anggaran } \\
\text { (Budget Authorization Document) }\end{array}$ \\
\hline DIY & - & $\begin{array}{l}\text { Daerah Istimewa Yogyakarta (Yogyakarta Special } \\
\text { Administrative Region) }\end{array}$ \\
\hline DJPPR & - & $\begin{array}{l}\text { Direktorat Jenderal Pengelolaan Pembiayaan dan Risiko } \\
\text { (Directorate General of Budget Financing and Risk Management) }\end{array}$ \\
\hline DMFAS & - & $\begin{array}{l}\text { Debt Management and Financial Analysis System of UNCTAD, } \\
\text { the United Nations Conference on Trade and Development }\end{array}$ \\
\hline DPR & - & Dewan Perwakilan Rakyat (House of Representatives) \\
\hline DRKH & - & Daftar Rencana Kegiatan Hibah (List of Planned Grant Projects) \\
\hline DRPLN-JM & - & $\begin{array}{l}\text { Daftar Rencana Pinjaman Luar Negeri Jangka Menengah } \\
\text { (List of Medium-Term Planned External Loans) }\end{array}$ \\
\hline DRPPLN & - & $\begin{array}{l}\text { Daftar Rencana Prioritas Pinjaman Luar Negeri } \\
\text { (List of Planned Priority External Loans) }\end{array}$ \\
\hline DSAK & - & $\begin{array}{l}\text { Dewan Standar Akuntansi Keuangan } \\
\text { (Indonesian Financial Accounting Standards Board) }\end{array}$ \\
\hline EAS & - & $\begin{array}{l}\text { Direktorat Evaluasi, Akuntansi, dan Setelmen } \\
\text { (Directorate of Evaluation, Accounting, and Settlement) }\end{array}$ \\
\hline$|A|$ & - & Ikatan Akuntan Indonesia (Indonesian Institute of Accountants) \\
\hline
\end{tabular}




\begin{tabular}{|c|c|c|}
\hline IFRS & - & International Financial Reporting Standards \\
\hline IPSAS & - & International Public Sector Accounting Standards \\
\hline IRM & - & Indonesia Resident Mission of ADB \\
\hline IRM-DU & - & Indonesia Resident Mission Disbursement Unit \\
\hline KEM-PPKF & - & $\begin{array}{l}\text { Kerangka Ekonomi Makro dan Pokok-Pokok Kebijakan Fiskal } \\
\text { (Macroeconomic and Fiscal Policy Framework) }\end{array}$ \\
\hline KPPN & - & $\begin{array}{l}\text { Kantor Pelayanan Perbendaharaan Negara } \\
\text { (Treasury Service Office) }\end{array}$ \\
\hline KSAP & - & $\begin{array}{l}\text { Komite Standar Akuntansi Pemerintahan } \\
\text { (Government Accounting Standards Committee) }\end{array}$ \\
\hline LC-POA & - & letter of credit with power of attorney \\
\hline LFIS & - & Loan Financial Information System of ADB \\
\hline LKPP & - & $\begin{array}{l}\text { Laporan Keuangan Pemerintah Pusat (financial report of the } \\
\text { central government) }\end{array}$ \\
\hline MOF & - & Ministry of Finance \\
\hline MOHA & - & Ministry of Home Affairs \\
\hline PIU & - & project implementation unit \\
\hline PKN & - & $\begin{array}{l}\text { Direktorat Pengelolaan Kas Negara (Directorate of State Cash } \\
\text { Management) }\end{array}$ \\
\hline PMP & - & $\begin{array}{l}\text { Panduan Manajemen Pemeriksaan (Audit Management } \\
\text { Guidelines) }\end{array}$ \\
\hline PMU & - & project management unit \\
\hline PSAK & - & $\begin{array}{l}\text { Pernyataan Standar Akuntansi Keuangan } \\
\text { (Indonesian Financial Accounting Standards) }\end{array}$ \\
\hline PSAP & - & $\begin{array}{l}\text { Pernyataan Standar Akuntansi Pemerintahan } \\
\text { (Statement of Government Accounting Standards) }\end{array}$ \\
\hline RBL & - & results-based lending \\
\hline $\mathrm{RPH}$ & - & Rencana Pemanfaatan Hibah (Grant Utilization Plan) \\
\hline RPJMN & - & $\begin{array}{l}\text { Rencana Pembangunan Jangka Menengah Nasional } \\
\text { (Medium-Term National Development Plan) }\end{array}$ \\
\hline RPPLN & - & $\begin{array}{l}\text { Rencana Pemanfaatan Pinjaman Luar Negeri } \\
\text { (Foreign Loan Utilization Plan) }\end{array}$ \\
\hline SAP & - & $\begin{array}{l}\text { Standar Akuntansi Pemerintahan } \\
\text { (Government Accounting Standards) }\end{array}$ \\
\hline SGTA & - & State General Treasury Account \\
\hline SLA & - & subsidiary loan agreement \\
\hline SMI & - & $\begin{array}{l}\text { Direktorat Sistem Manajemen Investasi } \\
\text { (Directorate of Investment Management System) }\end{array}$ \\
\hline SNG & - & subnational government \\
\hline SOE & - & state-owned enterprise \\
\hline SP3 & - & $\begin{array}{l}\text { Surat Perintah Pembukuan/Pengesahan } \\
\text { (record/endorsement order) }\end{array}$ \\
\hline SP4-HLN & - & $\begin{array}{l}\text { Surat Perintah Pembukuan Penarikan Pinjaban/Hibah Luar } \\
\text { Negeri (loan or grant withdrawal record order) }\end{array}$ \\
\hline SPAN & - & $\begin{array}{l}\text { Sistem Perbendaharaan dan Anggaran Negara } \\
\text { (Financial Management Information System) }\end{array}$ \\
\hline SPM & - & Surat Perintah Membayar (payment order) \\
\hline
\end{tabular}




\section{Introduction}

esigned to support fiduciary risk assessments of projects financed by the Asian

Development Bank (ADB), this report provides information about Indonesia's

public financial management systems for funds flow monitoring and analysis, accounting, auditing, and related matters, and will be particularly useful to project officers who process and implement ADB-funded projects. The information in this report may be leveraged in financial management assessments of executing and implementing agencies, as well as in the design of financial management arrangements such as disbursement and reporting and auditing.

This report applies to all loans and grants that finance clearly defined investment or public service programs (investment projects) and projects under financing agreements between the Government of Indonesia and ADB. Foreign aid to the Government of Indonesia takes the form of loans or grants. The loans can be made either to the government or to state-owned enterprises (SOEs) with a guarantee from the government. The government's decision to subgrant or onlend is based mainly on the ability of the proposed project to generate revenue. Subgrant funds are allocated through the central budget and the project owner has no obligation to repay. Onlent funds, on the other hand, are loaned from the central budget and must be repaid by the project owner. Subgrants or onlent funds are administered through the subsidiary agreements signed by the government with the project owners. Guarantees to SOEs are considered off-budget items and treated as contingent liabilities of the government in its annual financial statements. 


\section{Key Players}

\section{A. Ministry of Finance}

\section{Directorate General of Budget}

The Directorate General of Budget pursues the goal of high-quality budget management

to achieve sustainable and equitable development for the country. The budget proposals it submits to Parliament comprise estimated revenue, estimated expenditure, appropriations, and general provisions applicable to the appropriations. The main functions of this directorate general are:

(i) formulating and implementing budget preparation policies;

(ii) setting budget preparation norms, standards, and procedures;

(iii) disseminating budget circulars with guidelines for the preparation of ministry-specific work plans, including indicative budget ceilings;

(iv) participating in budget discussions with the National Development Planning Agency (BAPPENAS) and each spending agency to ensure robust costing of new initiatives;

(v) formulating macroeconomic and fiscal policies and discussing these with BAPPENAS;

(vi) providing technical guidance and supervision to spending agencies in budget preparation;

(vii) preparing and submitting budget proposals to Parliament;

(viii) preparing disbursement warrants for each spending unit; and

(ix) monitoring, evaluating, and reporting on the implementation of budget proposals, including recording foreign loans and grants, and reviewing progress every quarter.

\section{Directorate General of Budget Financing and Risk Management}

\section{Directorate of Loans and Grants}

The Directorate of Loans and Grants is the primary stakeholder in dealings with foreign donors. Its key functions are:

(i) formulating and implementing policies, standards, and procedures for loan and grant management;

(ii) identifying prospective foreign lenders;

(iii) analyzing the cost of borrowings;

(iv) coordinating negotiations between the government and donors; 
(v) reviewing draft loan or grant agreements and project planning documents;

(vi) preparing plans for the withdrawal of foreign funds according to the budget cycle;

(vii) providing technical guidance in, and monitoring and evaluating, the use of foreign funds;

(viii) developing effective work relationships with related parties in the government and donor agencies; and

(ix) preparing management reports on loan and grant implementation, and on the performance of the directorate.

\section{Directorate of Evaluation, Accounting, and Settlement}

The Directorate of Evaluation, Accounting, and Settlement (EAS) functions as the back office of the DJPPR in the handling of foreign loans and grants. Its involvement in negotiations with donors is minimal and is limited to recommending a suitable principal and interest amortization schedule for loans. The EAS carries out the following activities:

(i) participating in the DJPPR's trilateral meetings for budget preparation and revision;

(ii) meeting with line ministries to speed up disbursements;

(iii) obtaining quarterly reports on project implementation from the line ministries;

(iv) participating in trilateral meetings held by BAPPENAS to monitor and evaluate loan- and grant-funded projects;

(v) publishing quarterly reports on loan and project performance;

(vi) periodically reconciling outstanding debts and grants with creditors and donors;

(vii) periodically downloading data on loan and grant disbursements from ADB's Loan Financial Information System (LFIS) and extracting lending rates; and

(viii) downloading payment notices or invoices for loan payments falling due.

\section{Directorate General of Treasury}

\section{Directorate of State Cash Management}

The Directorate of State Cash Management (PKN) is one of eight directorates under the Directorate General of Treasury, responsible for cash management. It has six subdirectorates, individually responsible for (i) cash optimization; (ii) management of cash receipts and disbursements; (iii) the treasury dealing room and risk management; (iv) cash management of loans and grants; ( $v$ ) management of other accounts and accountabilities of the treasurer; and (vi) cash settlement, accounting, and reporting. Key functions of the PKN are as follows:

(i) drawing up cash and investment plans;

(ii) setting management policies for government revenue and expenditure accounts;

(iii) preparing a cash management strategy;

(iv) administering state accounts in Bank Indonesia and other commercial banks;

(v) administering special accounts (advance accounts) maintained for foreign loans and grants;

(vi) operating the government electronic banking system and transfers to and from the treasury single account; 
(vii) monitoring idle cash in state accounts and optimizing the use of funds in those accounts;

(viii) reporting budget realization and cash position;

(ix) consolidating the cash flow reports of the State Treasury Service Office (KPPN); and

(x) reconciling, accounting, and reporting the state revenues in the state accounts.

The PKN works with the 33 regional treasury offices and 183 local treasury offices reporting directly to the Directorate General of Treasury. The regional offices are mainly involved in coordination, guidance and support, monitoring and evaluation, and report preparation. The local treasury offices serve more than 24,000 spending units across Indonesia. Foreign loan transactions are routed through one of these local offices, which is referred to as the Special KPPN for Loans and Grants..

\section{Directorate of Accounting and Financial Reporting}

The main functions of the Directorate of Accounting and Financial Reporting are:

(i) supporting the development and implementation of Government Accounting Standards (SAP);

(ii) maintaining an accounting and financial analysis system for effective foreign aid use and public debt accounting;

(iii) developing and maintaining a standard chart of accounts;

(iv) implementing an accounting and financial reporting help desk to guide the preparation of financial statements;

(v) periodically consolidating the financial statements of ministries, agencies, and the National Treasury;

(vi) preparing the financial reports of the central government (LKPP);

(vii) preparing financial analyses of the government's financial results;

(viii) coordinating audit activities and the preparation of the government's response to the supreme auditor, the Audit Board of the Republic of Indonesia (BPK), regarding the LKPP; and

(ix) providing revenue and expenditure accounting information to Bank Indonesia, the International Monetary Fund, donors, and similar institutions.

\section{Directorate of Investment Management System}

The Directorate of Investment Management System (SMI) formulates investment management policies, procedures, and technical standards, and provides technical guidance in their implementation. It is responsible for onlending funds to SOEs and subnational governments (SNGs). Key activities of the SMI in this regard are as follows:

(i) participating in the DJPPR's tripartite meetings during the planning stage;

(ii) negotiating and signing subsidiary loan agreements (SLAs) with SOEs and SNGs;

(iii) obtaining the disbursement plans of executing agencies and submitting these to the DJPPR to support budget allocation or revision; 
(iv) recording SLAs in the Debt Management and Financial Analysis System (DMFAS), and in the Subsidiary Loan Management Information System for monitoring loan repayment;

(v) monitoring the progress of loan disbursement through quarterly and half-yearly reports; and

(vi) restructuring the nonperforming loans of SOEs and SNGs.

Besides its onlending functions, the SMI also prepares and implements policies for investment funds channeled through fund management agencies in the public sector, as well as policies for a credit-linked subsidy scheme for small business (small business credit program).

\section{Directorate General of Fiscal Balance}

Managing fiscal relations with SNGs is the responsibility of the Directorate General of Fiscal Balance. Its main task is formulating and implementing policies and technical standards to establish and maintain financial balance between the central government and the regions. Key functions are:

(i) preparing and implementing policies for the allocation and management of balancing funds (fiscal equalization funds) and transfers to regions, regional taxes, and regional levies;

(ii) formulating standards, norms, guidelines, criteria, and procedures for financial balance between the central government and the SNGs;

(iii) calculating and recommending the regions' share of the funds;

(iv) assessing the capacity of regions to implement projects when allocating funds and authorizing funding;

(v) discussing foreign fund allocations with BAPPENAS, and signing subsidiary agreements with SNGs;

(vi) providing technical guidance and monitoring their project progress and budget realization;

(vii) monitoring, evaluating, and reporting on balancing and nonbalancing funds transferred to SNGs; and

(viii) evaluating regional taxes and regional levies.

\section{Fiscal Policy Agency}

The Fiscal Policy Agency (BKF) $)^{1}$ formulates, determines, and recommends fiscal and financial sector policies in accordance with legislation. It prepares the state's Macroeconomic and Fiscal Policy Framework (KEM-PPKF), which contributes significantly to the preparation of the financial note with the state budget. The BKF also develops economic analyses and fiscal policy recommendations with regard to income, expenditure, and deficit financing. 


\section{B. Audit Board of the Republic of Indonesia}

The BPK is mandated under Article $23 \mathrm{E}$ of the Constitution to audit the central government, SNGs, other state institutions, Bank Indonesia, SOEs, public service agencies, region-owned enterprises and institutions, and other entities that manage state finances. The BPK conducts financial, performance, and special-purpose audits, and reports yearly to Parliament. The results of the state financial audit are submitted to the House of Representatives (DPR), the Regional Representative Council, and the Regional House of Representatives, in accordance with their authority. The BPK has been auditing foreign-funded projects since 2011.

\section{Financial and Development Supervisory Board}

The Financial and Development Supervisory Board (BPKP) is the internal auditor of the Government of Indonesia. It is mandated under Presidential Decree No. 192 of 2014 to

(i) formulate national policy for internal controls to ensure the proper use of public funds;

(ii) conduct regular and follow-up internal audits of state revenues and expenditure management by the central government, SNGs, and other institutions in which the government has financial interests; (iii) exercise internal control over the planning and implementation of state asset utilization; (iv) advise the government regarding internal controls and risk management; and (v) implement training and research and development programs in internal control systems. Besides internal audits to determine compliance with expenditure controls and performance of activities, the BPKP also conducts financial audits of some donor projects that began before 2011 and performs external audits of more recent projects on behalf of donors.

\section{National Development Planning Agency}

The main functions of BAPPENAS revolve around the formulation of national development plans - annual, midterm (5-year), and long-term - for the country including policy planning, assessment, and coordination. BAPPENAS also provides broad program support in the monitoring and evaluation of national development plan implementation.

BAPPENAS coordinates with international development agencies (unilateral, bilateral, and multilateral). It is mandated to plan for the proper use of external financing, under the Procedures for the Procurement of External Loans and Grants (Government Regulation No. 10 of 2011) and the Procedures for Planning, Proposing, Assessing, and Monitoring and Evaluating Activities Financed by Foreign Loans and Grants (Regulation No. 4 of the State Minister for National Development Planning/Head of BAPPENAS). The medium-term plan for external loan utilization is presented in the Foreign Loan Utilization Plan (RPPLN) and the List of Medium-Term Planned External Loans (DRPLN-JM). BAPPENAS assesses the 
project proposals submitted by line ministries, SNGs, and SOEs, and lists in the DRPLN-JM those projects that meet the eligibility criteria. It monitors these projects through quarterly reports submitted by the executing agencies and meets every quarter with line ministries, the Ministry of Finance (MOF), and relevant donors.

\section{E. Ministry of Home Affairs}

\section{Directorate General of Regional Finance Administration}

The Directorate General of Regional Finance Administration is tasked with formulating and implementing policies, and providing technical guidance and supervision for, regional financial development in accordance with the applicable legal provisions. The functions of the directorate general cover the following areas:

(i) supporting regional budget planning and preparation;

(ii) implementing and administering appropriate financial management systems in the regions, to record and report financial transactions and ensure regional financial accountability;

(iii) managing regional taxes and levies and other regional revenue systems;

(iv) providing loans and grants to regions; and

(v) facilitating the management of financial information systems in the regions.

Information about the project implementation challenges faced by the regions, in such areas as disbursements and staff capacity, are collated by the directorate and reported yearly to the Ministry of Home Affairs (MOHA).

\section{F. Bank Indonesia}

Bank Indonesia, the central bank, manages the country's foreign exchange reserves, conducts various foreign exchange transactions, and receives the proceeds of foreign borrowing. All special accounts or advance accounts related to foreign funds are opened and maintained at Bank Indonesia. Regarding public debt management, Bank Indonesia coordinates debt management operations with the MOF. It makes foreign currency available and pays donors at the MOF's request. Bank Indonesia and the MOF publish external debt data every quarter.

\section{G. Asian Development Bank}

\section{Controller's Department}

The Loan Administration Division of the Controller's Department of ADB (CTLA) authorizes all loans, grants, and technical assistance disbursements. The Loan and Treasury Accounting Section in the Accounting Division of the Controller's Department maintains accounting policies and systems for disbursements, billing and collection, and loan service payments. 


\section{Indonesia Resident Mission}

The CTLA delegates much of the processing of disbursements made for ADB-funded projects in the country to the Indonesia Resident Mission Disbursement Unit (IRM-DU). The IRM-DU processes withdrawal applications received from the MOF for direct payment, reimbursement, and advance fund procedures. 


\section{Budgeting}

\section{A. Project Financing Mechanism}

aw No. 17 of 2003 on State Finance empowers the Government of Indonesia to

receive loans and grants from foreign sources with the approval of the House of

Representatives. The President as the head of government holds power over state finances. The finance minister is delegated tasks related to fiscal management including entering into international financial agreements. Law No. 1 of 2004 on the State Treasury authorizes the finance minister as the state's general treasurer to borrow and provide guarantees on behalf of the government; lend on behalf of the government; and manage the state's debts and receivables. Under the same law, the finance minister may appoint an authorized official to secure state debt or receive grants from within the country or abroad on his behalf. In practice, loan and grant agreements with foreign donors, including $A D B$, are signed by the director general of budget financing and risk management on behalf of the government.

Government Regulation No. 10 of 2011 on Procedures for the Procurement of Foreign Loans and Grants and BAPPENAS Regulation No. 4 of 2011 set guidelines for obtaining foreign loans. The five stages of project management (Figure 1) are governed by these regulations.




Government Regulation No. 10 of 2011 requires Parliamentary approval for foreign loan financing as part of net value of loans approved along with the state budget. Changes in loans that do not exceed this net value do not have to be approved by Parliament. Each year, the finance minister prepares the government's plan for foreign loans, considering actual financing needs, ability to repay, cumulative limits, debt service capacity, and debt risk. Bank Indonesia may be consulted in the preparation of this plan, which is used in controlling government exposure to foreign loans.

Foreign loans obtained by the government are of two types: cash loans and activity loans. Cash loans, planned and procured with the finance minister in a coordinating role, finance state budget deficits and are used in debt portfolio administration. Activity loans, on the other hand, are planned by BAPPENAS and (i) finance the priority activities of ministries and agencies; (ii) are subloaned or given as grants to SNGs; or (iii) are channeled to SOEs. The following documents prepared by BAPPENAS outline the government's medium-term and annual plans for financing through activity loans:

(i) Foreign Loan Utilization Plan (RPPLN);

(ii) List of Medium-Term Planned External Loans (DRPLN-JM);

(iii) List of Planned Priority External Loans (DRPPLN); and

(iv) List of Activities.

The RPPLN is based on the Medium-Term National Development Plan (RPJMN) and takes into account the limits on government borrowing. It covers indicative needs for foreign loan utilization in the medium term, and may be revised and improved in line with needs or developments in the country's economy. The RPJMN, the government's 5-year national development plan, is based on its long-term strategy.

Ministries, agencies, and SOEs seeking foreign loans to finance proposed activities must submit their proposals to BAPPENAS, guided by the RPJMN and the RPPLN. Ministries and agencies may propose foreign loan funding for activities (i) directly performed by them as part of their duties and functions; (ii) to be funded with grants to SNGs; or (iii) to be carried out by several implementing agencies. Loans to be channeled to SNGs will be those within the government's authority and aimed at achieving RPJMN goals. Ministries may also propose foreign loan financing for SOEs to advance state equity, in which case the proposal must be submitted by the finance minister. SNGs may submit proposed projects for foreign funding to BAPPENAS, guided by the Regional Medium-Term Development Plan and the RPPLN. Loan proposals from the regions for foreign loan funding must be for activities to be funded with subloans or grants to the regions or to region-owned enterprises (Badan Usaha Milik Daerah). ${ }^{2}$ As for SOEs, they may propose activities to be funded with onloaned foreign funds. BAPPENAS Regulation No. 4 of 2011 gives detailed guidance on the requirements for proposals for foreign loan funding. SOEs may also borrow directly from foreign lenders, with the government acting only as guarantor. Such loans are considered off-budget items and the contingent liabilities are disclosed in the financial statements of the national government. 
BAPPENAS evaluates the feasibility of proposed projects, taking the RPPLN into account. It may seek the opinion of MOHA in assessing proposals from SNGs. Proposed projects that pass the preliminary assessment of BAPPENAS ${ }^{3}$ are included in the DRPLN-JM, which catalogs planned activities that can be feasibly funded with a foreign loan in the medium term. This list of medium-term development projects (the Blue Book) can be revised and updated as needed or according to developments in the national economy. Under BAPPENAS Regulation No. 4 of 2011, the minister of planning should set down the RPPLN at least within 3 months after the RPJMN is recorded, and the DRPLN-JM within 6 months, and convey the inclusion of projects in the DRPLN-JM to the finance minister and the head of the project-proposing ministry, agency, SNG, or SOE, as well as to the prospective source of the foreign loan.

Projects listed in the DRPLN-JM are next assessed for readiness by BAPPENAS according to their (i) implementation plan; (ii) performance indicators for monitoring and evaluation; (iii) organization and management plan for implementation activities; and (iv) land acquisition and resettlement plan, if land is required for the activities. ${ }^{4}$ Project proponents (ministries or agencies, SNGs, SOEs) must see to it that projects listed in the DRPLN-JM meet these readiness criteria. BAPPENAS may also communicate with the foreign lender in assessing project readiness. Projects that comply with the readiness criteria are included in the DRPPLN, which is a list of planned activities with secure funding, ready for annual financing with a foreign loan. This foreign loan priority scheme (the Green Book) cannot be revised. BAPPENAS conveys the DRPPLN to the finance minister, the project proponent, and the prospective foreign loan provider. Projects listed in the DRPPLN are included in the work and budget plans of the relevant ministries, agencies, SNGs, and SOEs.

Projects already in the DRPPLN and ready to be proposed to and negotiated with potential foreign lenders are then included in the List of Activities prepared by BAPPENAS. The List of Activities should at least (i) name the activity and the loan proposing and implementing agencies; (ii) state the funding amount, including matching or support funds; and (iii) indicate the funding source. The List of Activities is delivered to the finance minister for loan negotiation with prospective foreign lenders. The finance minister or an authorized official will negotiate the loan terms and conditions only after the readiness criteria are complied with. The various steps in the planning process are shown in Figure 2.

Grants received by the Government of Indonesia are to be used to support national development programs and natural disaster relief and humanitarian aid. These grants can be either planning or direct grants. Planning grants are received through the planning mechanism and BAPPENAS. Direct grants, on the other hand, are not implemented through the planning mechanism but involve the line ministry. In preparation for the grants, BAPPENAS draws up two documents outlining the medium-term and annual grant activities of the government-the Grant Utilization Plan (RPH) and the List of Planned Grant Projects (DRKH). 


\section{Figure 2: Steps in Planning}

\begin{tabular}{|c|c|c|c|c|c|}
\hline $\begin{array}{l}\text { Receive } \\
\text { proposals }\end{array}$ & $\begin{array}{c}\text { Assess } \\
\text { feasibility }\end{array}$ & $\begin{array}{l}\text { List in } \\
\text { DRPLN-JM } \\
\text { (Blue Book) }\end{array}$ & $\begin{array}{c}\text { Assess } \\
\text { compliance } \\
\text { with readiness } \\
\text { criteria }\end{array}$ & $\begin{array}{l}\text { Include in } \\
\text { DRPPLN } \\
\text { (Green Book) }\end{array}$ & $\begin{array}{c}\text { Include in List } \\
\text { of Activities }\end{array}$ \\
\hline $\begin{array}{l}\text { Receive proposals } \\
\text { for activities to be } \\
\text { financed with } \\
\text { foreign loans from: } \\
\text { - ministries and } \\
\text { agencies } \\
\text { - SOEs } \\
\text { - SNGs }\end{array}$ & $\begin{array}{l}\text { Assess project } \\
\text { feasibility } \\
\text { Get MOHA's } \\
\text { opinion about the } \\
\text { proposals }\end{array}$ & $\begin{array}{l}\text { List proposed } \\
\text { projects that pass } \\
\text { the preliminary } \\
\text { assessment } \\
\text { Convey list to: } \\
\text { - minister of } \\
\text { finance } \\
\text { - head of } \\
\text { proponent } \\
\text { institution } \\
\text { prospective } \\
\text { foreign loan } \\
\text { provider }\end{array}$ & $\begin{array}{l}\text { Base assessment on: } \\
\text { - implementation } \\
\text { plan } \\
\text { - performance } \\
\text { indicators for } \\
\text { monitoring and } \\
\text { evaluation } \\
\text { - organization and } \\
\text { management of } \\
\text { implementation } \\
\text { activities } \\
\text { land acquisition } \\
\text { and resettlement } \\
\text { plan, if land is } \\
\text { required for the } \\
\text { activities }\end{array}$ & $\begin{array}{l}\text { Convey the } \\
\text { DRPPLN to: } \\
\text { - minister of } \\
\text { finance } \\
\text { - project proponent } \\
\text { - prospective } \\
\text { foreign loan } \\
\text { provider }\end{array}$ & $\begin{array}{l}\text { Deliver the list to } \\
\text { the minister of } \\
\text { finance for loan } \\
\text { negotiation with } \\
\text { prospective foreign } \\
\text { loan provider }\end{array}$ \\
\hline
\end{tabular}

DRPLN-JM = Daftar Rencana Pinjaman Luar Negeri Jangka Menengah (List of Medium-Term Planned External Loans); DRPPLN = Daftar Rencana Prioritas Pinjaman Luar Negeri (List of Planned Priority External Loans); MOHA = Ministry of Home Affairs; RPPLN = Rencana Pemanfaatan Pinjaman Luar Negeri (Foreign Loan Utilization Plan); SNG = subnational government; SOE = state-owned enterprise.

Source: Author's representation.

Based on the RPJMN, the RPH lays out the government's policy directions, strategy, and use of grants in the medium term, and may be revised as needed. Grant-seeking agencies must submit proposals to BAPPENAS guided by the RPJMN and the RPH, and considering the grant principles and the intended use of the grants. The proposals may also include planned activities of SNGs.

BAPPENAS assesses the grant proposals for technical feasibility and alignment of planned activities with the RPH, with directly related activities of other agencies, and with the performance of activities under existing grants at the proposing or implementing agencies. The assessment of technical feasibility is based on (i) conformity with RPJMN programs and priorities; (ii) conformity with grant principles; (iii) conformity with the duties and functions of the implementing agencies; (iv) availability of satisfactory implementation plans, including disbursement and work plans; ( $v$ ) connection between the proposed activities and the other activities of the grant-seeking agencies; and (vi) agency capacity to provide matching or support funds, if required. Depending on the outcome of the feasibility assessment, BAPPENAS prepares the DRKH, which lists the planned annual activities suited to grant financing, in cases where funding indications have already been received from prospective grantors. BAPPENAS conveys the DRKH to the heads of the proposing agencies and to the finance minister for use in proposals to prospective grantors.

As mentioned earlier, Law No. 17 of 2003 authorizes the central government to receive grants and loans from foreign governments and institutions. It also provides for the 
onlending of such loans and grants to SNGs, state enterprises, and local companies. Loans and grants received by the government are implemented as part of the state budget (APBN). Foreign loans received by the government and categorized as activity loans are used for priority activities of the finance ministry and the various agencies, subgranted or loaned to SNGs or loaned to SOEs, and implemented through the state budget. Since 2007, only a limited number of SNGs have been interested in obtaining foreign loan funding. SNGs can generally source adequate funding to meet their contributions to projects, and seek foreign loan funding only for large infrastructure development projects.

The project approval process is generally lengthy and time-consuming (Figure 3 ). This is especially the case for large infrastructure development projects that require land acquisition. The government has adopted a new policy to expedite land acquisition for projects. It involves the allocation of adequate funds and central government coordination of all land acquisition matters. Previously, project proponents had to work with SNGs to have regional land allocated for projects, thus delaying project implementation.

$A D B$ results-based lending ( $R B L$ ) is a new instrument for Indonesia. It is perceived as not being directly compatible with either cash loans handled by the finance minister or activity loans handled by the minister of planning. Planning, recording, reporting, and monitoring systems for public financial management in Indonesia are designed to cater to cash loan or activity loan requirements. At first, therefore, RBL was pursued only with SOEs, which are not subject to these systems. For other entities, RBL will require project-by-project discussions between the ADB project team and the relevant line ministries and agencies to arrive at an agreement on the appropriate financial management arrangements. The government is exploring ways of facilitating RBL within the current government systems. ${ }^{5}$

\section{B. State General Treasury Account}

Act No. 1 of 2004 on the State Treasury established the State General Treasury Account (SGTA) as the depository account into which all state revenue is paid and from which all state expenditure is made. Empowered by the law, the finance minister, as the state treasurer, opened the SGTA with the central bank and takes charge of the account. The minister is also authorized to open receiving and spending accounts with commercial banks. The receiving accounts hold daily state revenues, and the entire balance is transferred to the SGTA with the central bank at the end of each workday. The funds in the spending accounts, on the other hand, come from the SGTA and are adjusted to meet the spending needs of activities in the state budget.

The SGTA with Bank Indonesia is maintained in four currencies-Indonesian rupiah, Japanese yen, United States dollars, and euros. The government collects its revenue through 81 commercial banks and through the post office, ${ }^{6}$ and maintains spending accounts with four state-owned banks-Bank Mandiri, Bank Negara Indonesia, Bank Rakyat Indonesia, and Bank Tabungan Pensiunan Nasional. With the implementation of the SGTA in 2009, each local treasury services office (KPPN) is allowed to maintain only two spending accounts with commercial banks. The Operational Bank I (BO-I) account is used

According to information gathered during consultations with government agencies on 18-26 April 2016.

World Bank. 2014. Indonesia Cash Management Reform. Washington, DC. p. 71. 


\section{Figure 3: Project Loan Processing System}

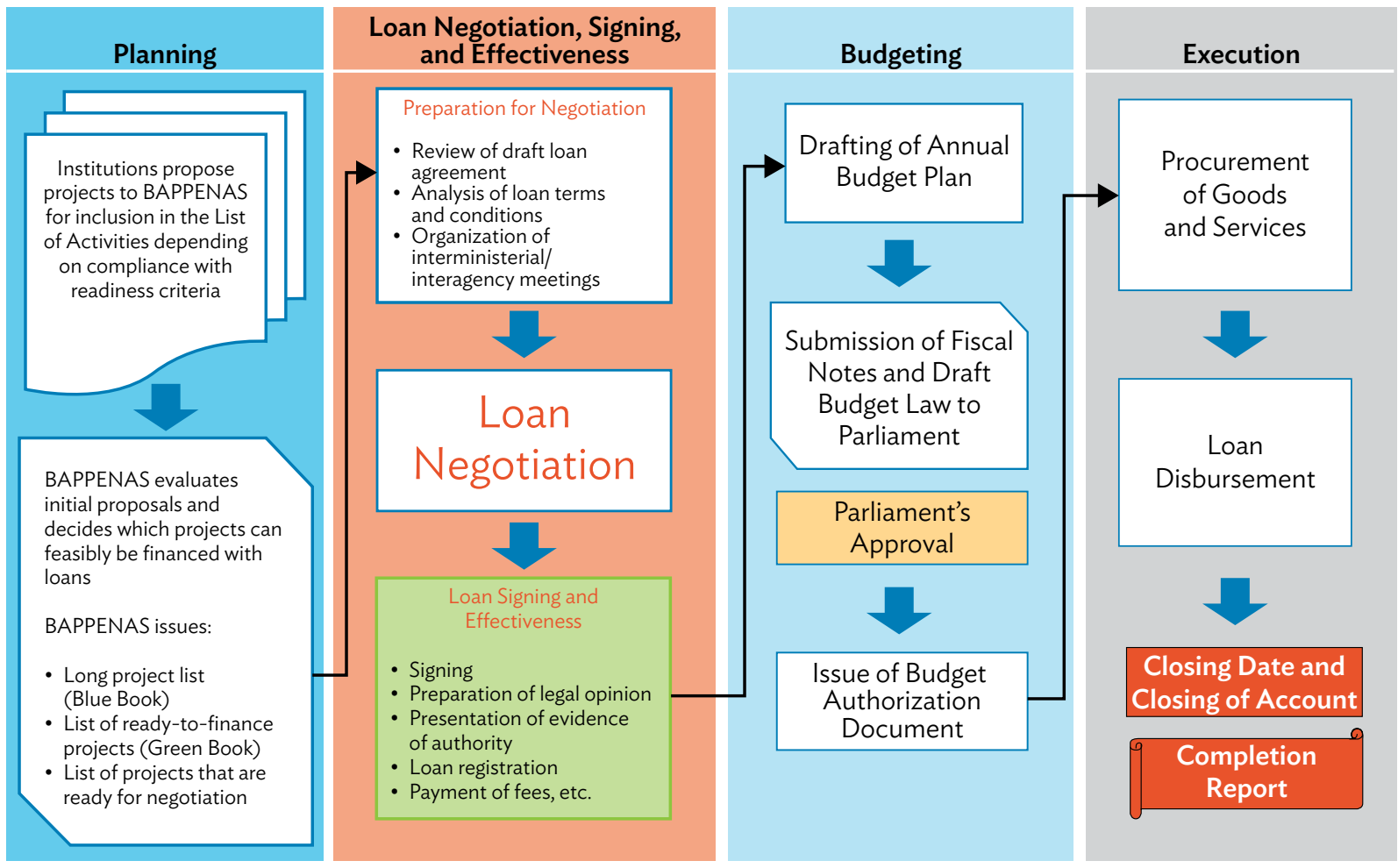

BAPPENAS = Badan Perencanaan Pembangunan Nasional (National Development Planning Agency).

Source: Directorate General of Budget Financing and Risk Management, Ministry of Finance (adapted).

for nonsalary expenditures, such as the purchase of goods, and the Operational Bank II (BO-II) account, for salary expenditures.

Foreign funds for projects are held in special accounts (advance accounts) at the central bank; when disbursed, these funds flow into the state treasury account. All payments related to foreign funds are coordinated through the KPPN Special Account for Loans and Grants (Special KPPN).

\section{Budget Recording and Reporting}

The financial statements of the central government and the SNGs are the state and regional budget accountability reports. Law No. 17 of 2003 on State Finance requires compliance with the SAP in the preparation of these reports. Government Regulation No. 71 of 2010 on Government Accounting Standards states the accounting principles to be applied in the preparation and presentation of the government's financial reports. While revenue, expenditure, assets, debt, and equity were traditionally recognized and recorded on a cash 
basis, accrual-based standards would be adopted after a transition period (2010-2014, according to the regulation). During the transition, revenue and expenditure would continue to be recognized on a cash basis; all other reporting (on assets, debt, and equity) would be accrual-based. Further provisions for the implementation of accrual-based SAP are found in regulations of the MOF (for the central government) and the MOHA (for SNGs).

The transition began earlier, in 2004 instead of 2010, but the target date for recognizing and measuring accrual-based revenue and expenditure was moved from 2008 to 2015 . In its financial statements for 2015, the government adopted full accrual-based accounting standards for the first time. Figures 4 and 5 summarize the stages in the gradual adoption of accrual-based accounting in Indonesia.

Under MOF Regulation No. 84 of 2015, if budget allocations for foreign loans and grants in the form of direct financing, letters of credit, or prefinancing remain unrealized until the current budget year-end, the ministry or institution must allocate these funds in the Budget Authorization Document (DIPA) for the next fiscal year. However, activities with a closing date coinciding with the financial year-end (and thus cannot be carried forward) and a date of notice of disbursement after the closing date shall be settled through the issuance of a decree by the finance minister. This decree will serve as basis for administrative budget allocations and as reference in the issuance of payment vouchers (SP3).

Unspent budget allocations that need to be carried over must undergo internal audit by the relevant ministry or institution, or by the Financial and Development Supervisory Board (BPKP). If the value to be carried over is up to Rp2 billion (about $\$ 150,000$ ), the review will be done by the Inspectorate General of the MOF; over that amount, the allocations will be reviewed by the BPKP. Once a satisfactory review is completed, the budget allocation will be made for the next fiscal year, with a note from the BPKP in the financial statement for the current year indicating that payment will be made the following year.

Figure 4: Timeline for the Adoption of Accrual-Based Accounting Standards

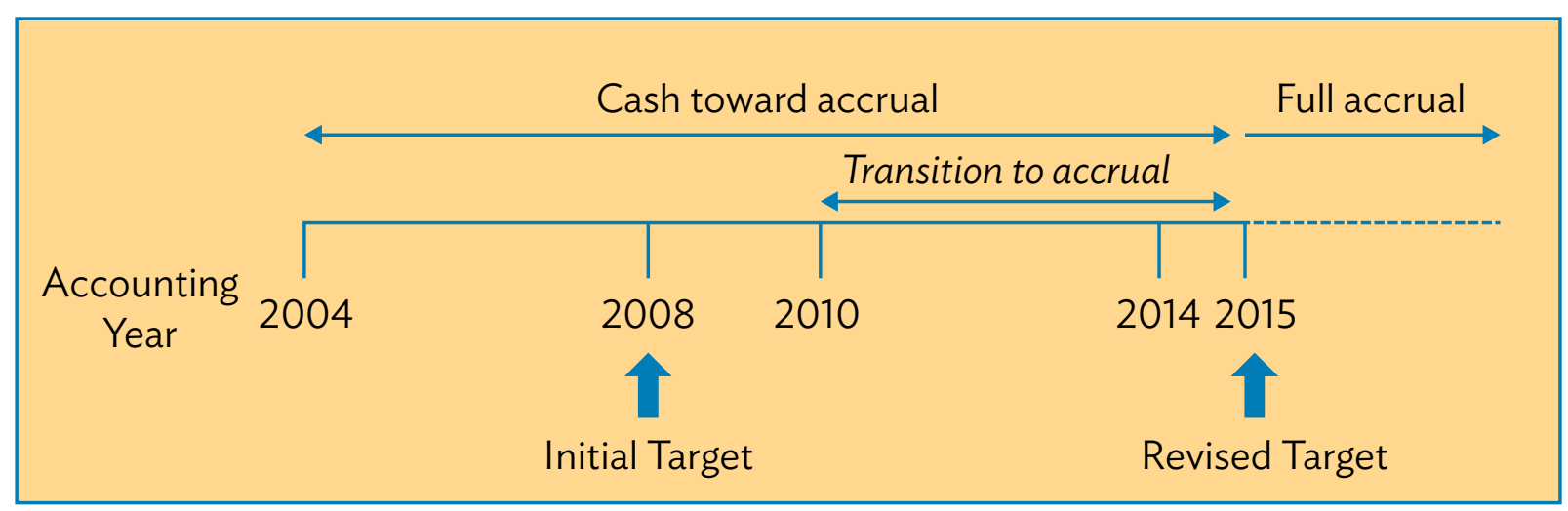

Source: Author's compilation. 


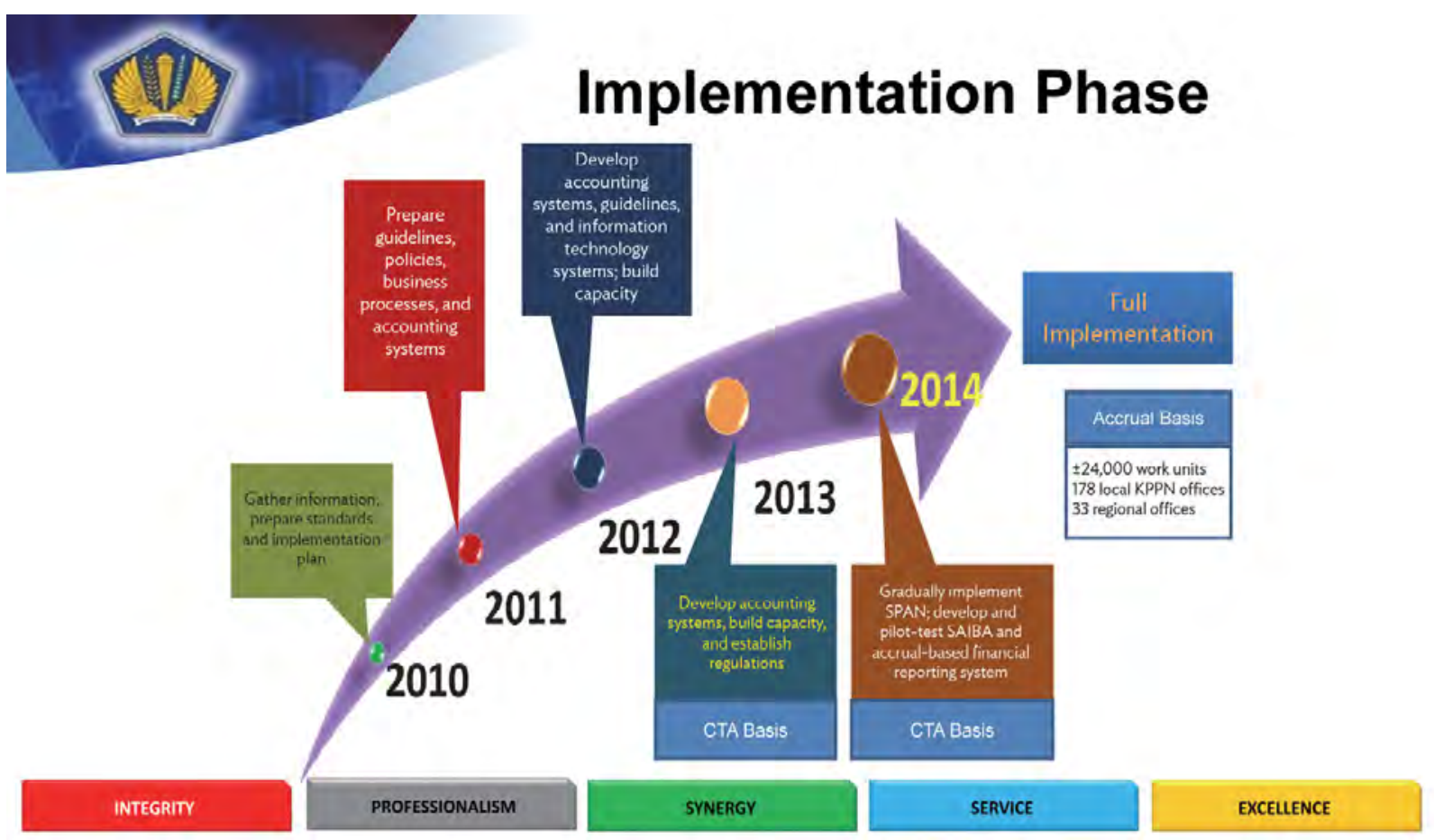

CTA = cash toward accrual; KPPN = Kantor Pelayanan Perbendaharaan Negara (State Treasury Service Office); SAIBA = Sistem Akuntansi Instansi Basis Akrual (Accrual-Based Government Accounting System); SPAN = Sistem Perbendaharaan dan Anggaran Negara (Financial Management Information System).

Source: Directorate of Accounting and Financial Reporting, Ministry of Finance (adapted).

\section{Budget Process}

Budget preparation in Indonesia derives its legal force from the Constitution (Article 23 of Chapter VIII), which bases state fund management on the annual budget bill. The budget process is regulated under Law No. 17 of 2003 on State Finance; Law No. 25 of 2004 on the National Development Planning System; Government Regulation No. 90 of 2010 on the Preparation of the Work Plan and Budget for the State, Ministries, and Institutions; annual MOF regulations on guidelines for the preparation and review of ministry work plans and budgets, and on DIPA legalization; as well as other relevant circulars and guidelines.

Indonesia has a three-tier administrative structure made up of the national government, 34 provinces, and districts and cities. The People's Consultative Assembly is the legislative body at the national government level. The Regional Representative Councils, formed under Law No. 22 of 1999 on Local Government (later replaced by Law No. 23 of 2014), legislate on provincial matters. At the local level, the districts and cities have their own legislative bodies. 
Law No. 33 of 2004 on Fiscal Balance between the Central and Regional Governments and Law No. 23 of 2014 on Local Government transferred administrative and financial autonomy from the central government to the SNGs. An appendix to Law No. 23 of 2014 describes the division of powers between the central government and the SNGs. The classification of government affairs under Law No. 33 of 2004 is shown in Figure 6.

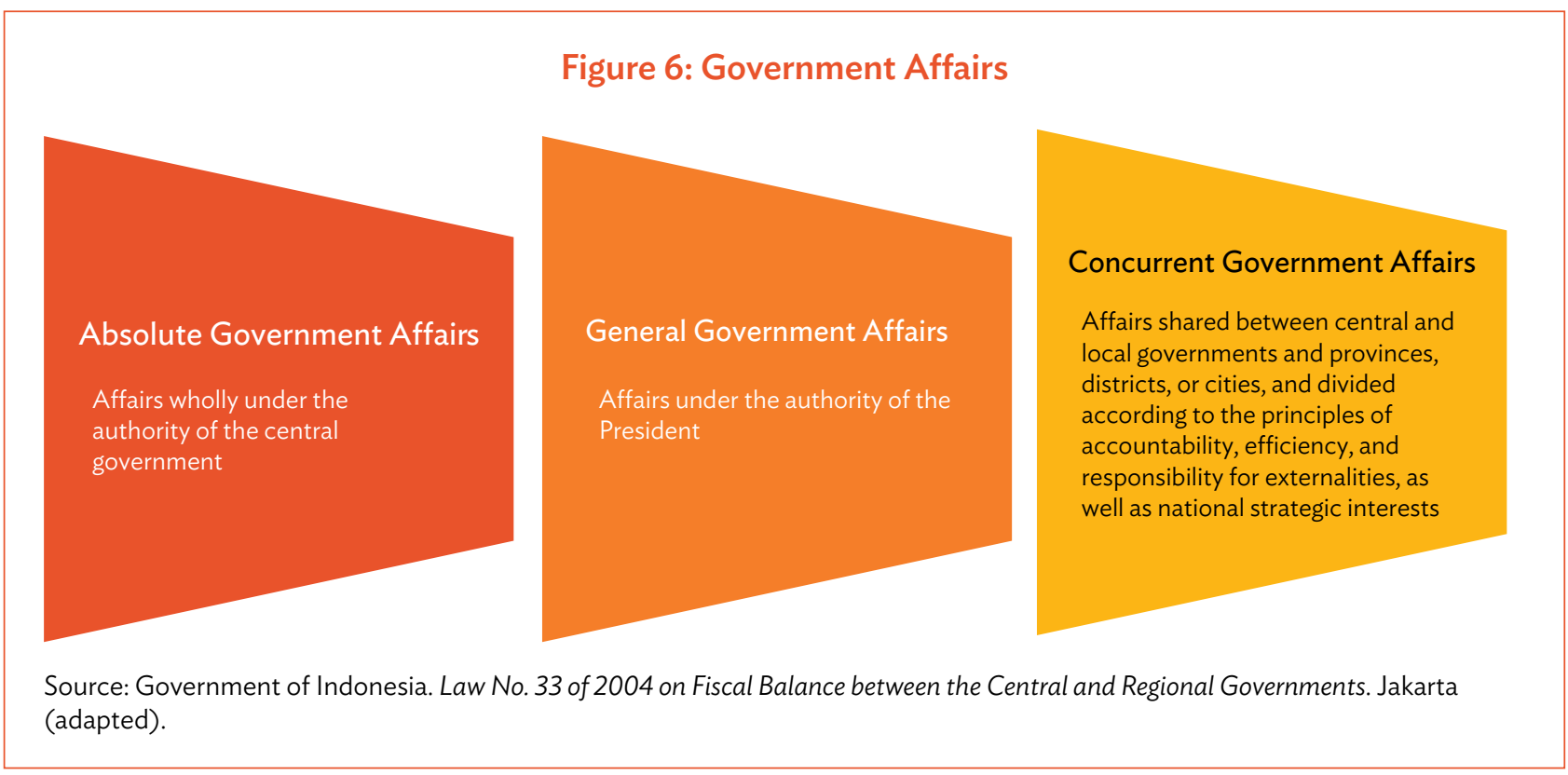

Budgets are prepared at the state and regional levels and must be approved by the relevant legislative councils. The state budget is based on the government work plan and includes expenditures for the implementation of central government tasks as well as the financial balance between the central government and the SNGs. The regional budget is based on the annual work program of the SNG (province, district, or city), which in turn is based on the national work program and regional priorities.

\section{Central Budget}

The Directorate General of Budget formulates the state budget. Indonesia has a welldefined budget process and a classification system aligned with international standards, and has adopted performance-based budgeting and medium-term expenditure forecasting (Figure 7). State budget expenditure consists of (i) central government expenditure, subdivided into line ministry expenditure (ministries and institutions) and nonline ministry expenditure (state treasurer); and (ii) transfers to regional and rural funds (Figure 9). Budgeting for transfers to regional and rural funds is made in cooperation with the Directorate General of Fiscal Balance, and these funds go into the local budgets. State budget revenues come from customs duties and excise taxes, nontax revenues, and grants.

Budget classification is governed under MOF Regulation No. 127 of 2015, which breaks down state budget expenditures according to organization, function, and type 
Figure 7: Central Government Budget Cycle

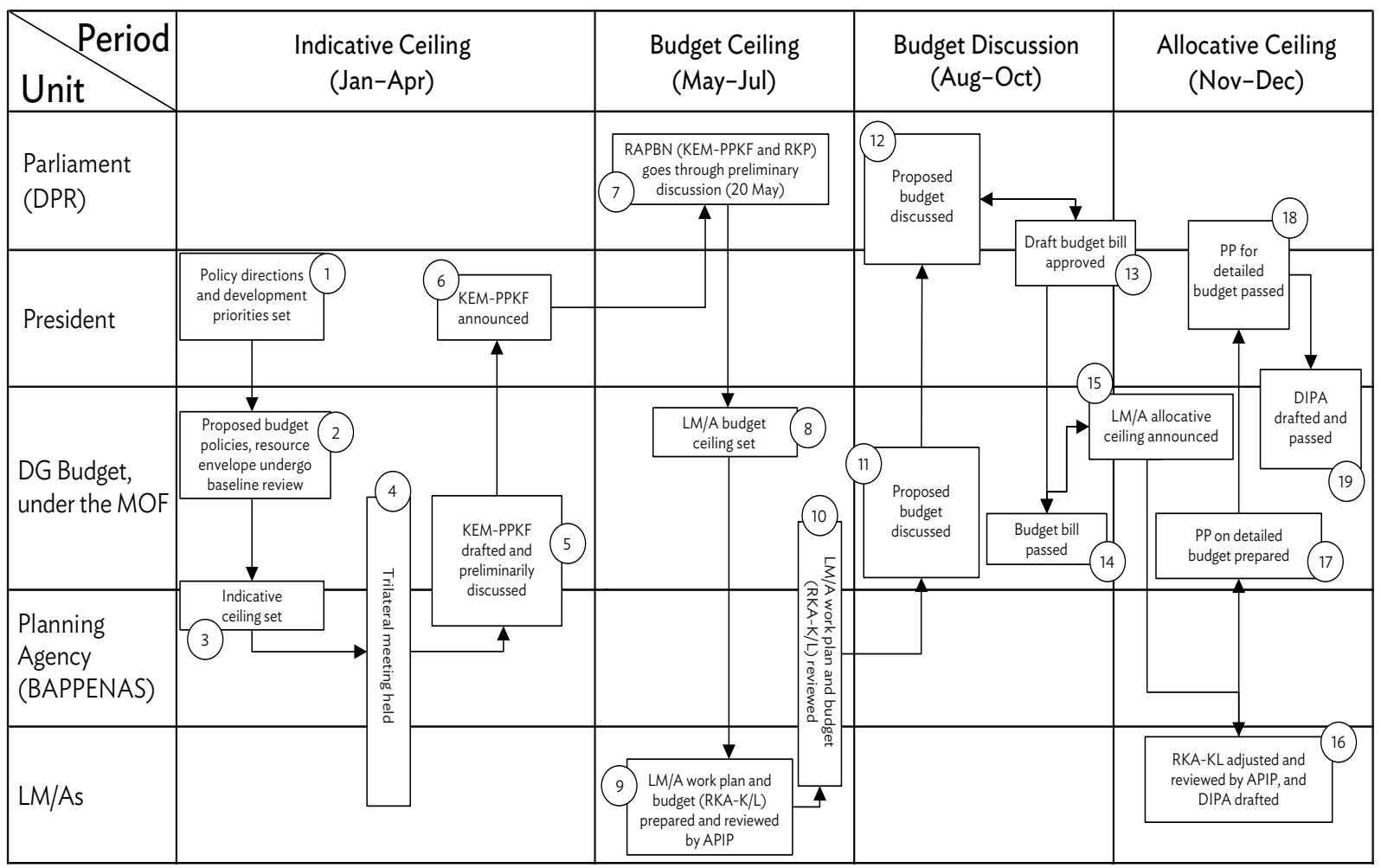

APIP = Aparat Pengawasan Intern Pemerintah (Government Internal Audit Structure); BAPPENAS = Badan Perencanaan Pembangunan Nasional (National Development Planning Agency); DG = directorate general; DIPA = Daftar Isian Pelaksanaan Anggaran (Budget Authorization Document); DPR = Dewan Perwakilan Rakyat (House of Representatives); KEM-PPKF = Kerangka Ekonomi Makro dan Pokok-Pokok Kebijakan Fiskal (Macroeconomic and Fiscal Policy Framework); $\mathrm{K} / \mathrm{L}=$ Kementerian/Lembaga (ministry/agency); $\mathrm{LM} / \mathrm{A}=$ line ministry/agency; $\mathrm{MOF}=$ Ministry of Finance; $\mathrm{PP}=$ Peraturan Pemerintah (government regulation); RAPBN = Rencana Anggaran Pendapatan dan Belanja Negara (Draft of State Budget); RKA-KL = Rencana Kerja Anggaran Kementerian Lembaga (Work Plan of the Ministry of Budget); RKP = Rencana Kerja Pemerintah (Government Work Plan).

Source: Department of Budget, Ministry of Finance (adapted).

of expenditure, and lists the corresponding budget codes in Appendixes I, II, and III of the regulation.

Government Regulation No. 90 of 2010 requires budget preparation based on medium-term expenditure forecasting, integrated budgeting, and performance-based budgeting. Medium-term expenditure forecasting provides a baseline for future costs of existing programs, allowing for multiyear costing of programs, thus ensuring that budget proposals are based on forward estimates from the previous year. In Indonesia, the forward estimates for the next 3 years $(t+1, t+2$, and $t+3)$ are updated around January-February of the current year, in the light of government policies and the budget realization of the previous year $(t-1)$. The baseline review for the next year is completed by February-March, and the resource envelope and indicative ceilings for the next year's budget are based on that review. 
Fulfilling a fundamental prerequisite of performance-based budgeting, line ministries have set targets and indicators for evaluating the performance of programs and activities. ${ }^{7}$ Guidance for this process comes from the MOF and its Regulation No. 249 of 2011 on the Measurement and Evaluation of the Implementation of the Work Plan and Budget of the Line Ministries. To facilitate performance-based budgeting, targets and indicators for new programs were incorporated in the RPJMN 2010-2014, and first implemented in the 2011 budget. ${ }^{8}$ After evaluating the implementation in 2012, the MOF issued Regulation No.136/PMK.02/2014 to provide further guidance for a logic-based outline and facilitate more relevant and clearer performance measurement. ${ }^{9}$

Every year, the MOF issues two regulations-one to ministries and institutions and the other to the state treasurer-detailing the budget preparation procedures for line ministry expenditure (Regulation No. 196/PMK.02/2015) and nonline ministry expenditure (MOF Regulation No. 231/PMK.02/2015).

The budgeting process in Indonesia is well defined. The state budget, state budget amendment, and accountability for budget implementation each year are set forth by law.

The bill on the state budget submitted by the President must be decided on by Parliament 2 months before the end of the fiscal year, by the end of October. However, if the budget is not approved by Parliament, the Constitution provides for the reenactment of the state budget for the previous year. Until 2015, the state budget passed by the House of Representatives was detailed up to the organizational unit, function, program, activity, and type of expenditure. Since 2016, however, state budgets approved by Parliament have contained details only up to the organizational unit, function, and program. This change resulted from Constitutional Court Decision No. 35/PUU-XI/2013 of 22 May 2014, which partly reduced the authority of the budgetary board of the House of Representatives. As a result, the budgetary board no longer discusses other expenditure details with the government. ${ }^{10}$

The World Bank publication Cash Management Reform in Indonesia: Making the State Money Work Harder (2014) notes a unique final step in the country's budget formulation process. Following Parliamentary approval of the draft budget bill and communication of allocated ceilings by the MOF, each spending ministry must prepare detailed budget allotment documents for budget users within its purview. The Budget Authorization Document (DIPA) is based on these budget allocation documents. The ministries are thus given budget authority through the DIPA, which must be approved before the start of the year. The DIPA approved by the MOF is submitted to the minister or head of the institution who is the proxy to the state's general treasurer, and to the BPK. Passing the budget bill by the end of October is believed to give the ministries enough time to prepare the allocation documents, issue the presidential regulation, and formulate and give legal validity to the DIPA through circulars.

ADB. 2015. Report and Recommendation of the President to the Board of Directors: Public Financial Management Assessment of the Financial Market Development and Inclusion Program (Subprogram 1). Manila (RRP 48207-002-INO).

8 World Bank. 2012. Indonesia: Repeat Public Expenditure and Financial Accountability (PEFA) Report and Performance Indicators. Washington, DC.

Ministry of Finance. 2014. Economic Stability for Prosperity: Annual Report. Jakarta.

10 Ministry of Finance. 2014. Economic Stability for Prosperity: Annual Report. Jakarta. 
However, timely budget execution has faced challenges. ${ }^{11}$ Some DIPAs have been delayed up to a few months because the relevant Parliamentary review committees could not complete the review by the start of the fiscal year, or because the line ministries had not reappointed staff of spending units with authority to implement the budget. Although the budget is formally approved in October, sectoral commissions in Parliament have released funds only after concerns (usually relating to incomplete or inaccurate supporting documents) are addressed by the spending units. Another impediment has been the very detailed Parliamentary approval of the budget, limiting the flexibility to shift budget allocations. These challenges are now being addressed, through Constitutional Court Decision No. 35/PUU-XI/2013, which has resulted in Parliamentary budget approval only by organizational unit, function, and program. The court also removed the Audit Board's authority to block spending-unit budgets with incomplete or inaccurate documentation. ${ }^{12}$ After final budget approval, the Directorate General of Budget prepares detailed disbursement warrants and issues them to more than 24,000 budget users, who must respect the breakdown, as reallocations (virements) are exceedingly difficult to arrange, even within spending units.

Indonesian law also requires the central government to submit Parliament a realization report on the implementation of the State Budget in the first half of the year and the outlook for the next 6 months before the end of July of the current fiscal year. Midyear budget revisions reflect changes in macroeconomic and fiscal assumptions. In practice, budget revisions have been made yearly since 1999. The revisions generally occur around July-August, after the midyear report is presented to Parliament. The MOF and the Cabinet decide on the needed reallocation, which involves budget revision by all ministries and agencies. The revised budgets are then approved by Parliament and the DIPA is revised to conform to the new Budget Act. It usually takes around 1 month for budgets to be revised and approved.

Much of the spending is skewed toward the second half of the year. At national and subnational levels, typically $50 \%-60 \%$ of capital spending is disbursed in the last quarter, contributing to the poor implementation of the budget for public investment. These delays are largely attributed to cumbersome and complicated reallocation and to constraints on the capacity of spending units to fulfill their functional responsibilities. The new cash management system introduced in 2015 by the MOF is expected to speed up budget execution at the national level. ${ }^{13}$

\section{Local Budgets}

The President, as head of state financial management, has delegated to the SNG heads (governors, regents, mayors) his power to manage local finances and represent ownership of separate regional assets, under Law No. 17 of 2003 on State Finance. This power is exercised at the regional level by the head of regional financial management work units as regional budget manager, and by the head of regional work units as regional budget user.

World Bank. 2014. Cash Management Reform in Indonesia: Making the State Money Work Harder. Washington, DC; World Bank. 2007. Indonesia: Public Expenditure and Financial Accountability (PEFA). Washington, DC.

Ministry of Finance. 2014. Economic Stability for Prosperity: Annual Report. Jakarta.

ADB. 2015. Summary of Indonesia's Public Sector Management Sector Assessment. Papers on Indonesia. No. 11. Manila. 
Under Law No. 33 of 2004 on Fiscal Balance between the Central and Regional Governments, SNG income is derived mainly from regional revenue and financing. Regional revenue consists of (i) regional own revenue, which is revenue raised locally through decentralization; (ii) the balancing fund, which is the central government's allocation to a region to finance its decentralization needs; and (iii) other income, from grants and emergency funds. Regional financing, on the other hand, comprises (i) the remaining balance in the regional budget, (ii) regional loans, (iii) the regional reserve fund, and (iv) proceeds from the sale of regional assets set aside for the purpose.

The local revenue and expenditure budget (APBD) is the annual financial plan of the region, which is approved jointly by the SNG (represented by the governor, district head, or mayor) and the regional house of representatives, and is established yearly as a regional regulation. It consists of the revenue, expenditure, and financing budgets. The revenue budget is derived from regional own revenue, the balancing fund, and other income. Law No. 33 of 2004 on Fiscal Balance between the Central and Regional Governments requires a breakdown of the expenditure budget by organization, function, program, activity, and type of expenditure. The local budget is regulated by the MOHA.

Law No. 33 of 2004 also provides the basis for fair, proportional, democratic, transparent, and efficient revenue sharing between the central government and the SNGs, in a comprehensive system of financing for decentralization, deconcentration, and co-administration of tasks. Decentralization refers to the transfer of government authority to an autonomous region; deconcentration, to the delegation of authority to the governor as representative of the government; coadministration, to the assignment of tasks to a region, village, or other entity, which must account for their implementation to the central government.

The delegation of authority from the central government to the SNGs through deconcentration and coadministration, under Law No. 33 of 2004, includes the provision of funds through the state budget (APBN). Funding for such activities is allocated through the line ministries by means of the deconcentration and coadministration funds, and does not go into the SNG budget. The deconcentration fund, administered by the governor as the representative of the government, consists of all revenues and expenditures resulting from deconcentration, excluding funds allocated to central government agencies in the region. The coadministration fund is administered by the SNG and consists of all revenues and expenditures arising from the implementation of coadministered tasks.

However, the administration of SNG affairs in the implementation of decentralization is funded directly through the APBD, which consists of funds sourced from the APBN as transfers to regional and rural funds. These fund transfers are captured in the state budget as a separate line item. The balancing fund is the region's main source of financing for SNG decentralization. The special autonomous and adjustment funds are obtained from other sources of regional funds for the use of specific SNGs or for other specific purposes. Rural funds, derived from the village fund, are allocated to the villages to support programs under their authority.

The balancing fund is intended to narrow the fiscal gap between the central government and the SNGs, and to reduce the funding gap between SNGs. This fund consists of (i) the 
Revenue-Sharing Fund (DBH), (ii) the General Allocation Fund (DAU), and (iii) the Special Allocation Fund (DAK). The amount of funding for each fund is established annually through the APBN.

The DBH is sourced from taxes and natural resources and allocated to a region at a certain percentage based on section VI (part two) of Law No. 33 of 2004. The DAU is a regional allocation of at least $26 \%$ of net domestic revenue established in the APBN to equalize financial capacity among the regions. DAU allocation is based on the fiscal gap and basic allocation, as detailed in section VI (part three) of Law No. 33 of 2004. The provinces are allocated $10 \%$ of the DAU, and the municipalities, $90 \%$. The regional allocation of the DAU is based on a formula that considers local needs and potential. ${ }^{14}$ The DAK is sourced from revenue in the APBN and allocated to specific regions to fund their special activities in accordance with national priorities, based on section $\mathrm{VI}$ (part four) of Law No. 33 of 2004. Regions receiving DAK funding, except those with a certain fiscal capacity, used to be required to provide $10 \%$ of their DAK allocation as matching funds through the APBD. No matching funds were required from regions with a specified level of fiscal capacity. This requirement was reduced in fiscal year 2013 and abolished in 2016.

The Special Autonomy and Adjustment Funds, based on APBN 2014, consist of (i) the Special Autonomy Fund, (ii) the Special Fund for the Yogyakarta Special Administrative Region (DIY), and (iii) the Adjustment Fund. The Special Autonomy Fund supports the special autonomous provinces of Aceh, Papua, and West Papua, and the Yogyakarta Special Administrative Region; the Special Fund for DIY, the implementation of DIY authority. The Special Fund for DIY is allocated specifically for the implementation of DIY authority. The Adjustment Fund supports improvements in educational quality, and consists of Professional Allowances for Regional Civil Servant Teachers (PNSD), Additional Income for PNSD Teachers Fund, the School Operational Assistance Fund, the Regional Incentive Fund, and the Local Government and Decentralization Project Fund. ${ }^{15}$ Since 2015 , the structure of transfers to regions and villages has changed, as shown in Figure 8.

As required under Law No. 6 of 2014 on Villages, APBN funds have been allocated to all villages since 2015 , to support programs under village authority, including administration, development, community empowerment, and social development. ${ }^{16}$ Transfers to villages are allocated in the APBN as transfers to regional development and village funds.

Borrowings constitute another source of financing for local budgets. Under Law No. 17 of 2003 on State Finance, the central government may provide loans or grants to SNGs, and SNGs may lend or borrow with the approval of the Legislative Council. SNG borrowings can come from the central government, other SNGs, banks and nonbank financial institutions, or the general public. But SNGs may not borrow directly from foreign sources. Foreign grants must also go through the central government. Under Act No. 1 of 2004 on the State Treasury, all costs associated with regional loans and grants are imposed on

Ministry of Finance. 2015. Economic Stability for Prosperity: Annual Report 2014. Jakarta. p. 189.

Ministry of Finance. 2015. Economic Stability for Prosperity: Annual Report 2014. Jakarta. pp. 185, 191-193.

Ministry of Finance. 2015. Economic Stability for Prosperity: Annual Report 2014. Jakarta. pp. 184, 196. 
Figure 8: Changes in the Structure of Fund Transfers to Regions and Villages, 2014-2017

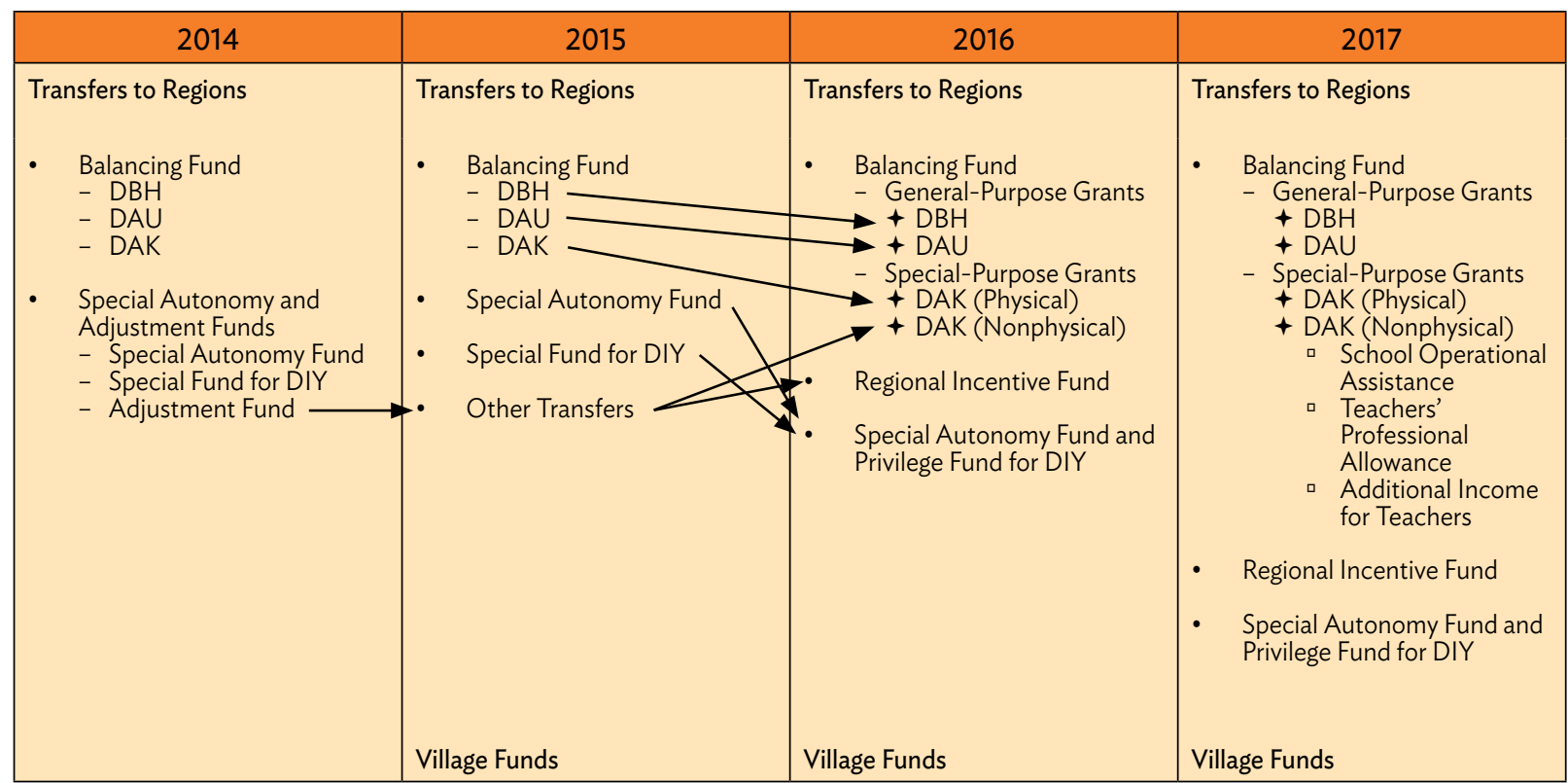

DAK = Dana Alokasi Khusus (Special Allocation Fund); DAU = Dana Alokasi Umum (General Allocation Fund); DBH = Dana Bagi Hasil (Revenue-Sharing Fund); DIY = Daerah Istimewa Yogyakarta (Special Region of Yogyakarta).

Notes:

1. DAK (Physical) funds are intended for the development of physical infrastructure for subnational governments.

2. Village funds were first allocated in 2015.

Source: Department of Budget, Ministry of Finance (adapted).

the APBD. Figure 9 shows the overall process of allocating funds from the state budget to local governments.

The MOHA is the intermediary between the central government and the SNGs in financial matters. Its Directorate General of Regional Finance formulates and implements policies for regional financial development. According to Presidential Regulation No. 11 of 2015 on the Organizational Structure of the MOHA, the responsibilities of the directorate general include coordinating regional budget planning, preparation, implementation, and monitoring, as well as financial accounting and reporting; the management of financial investment in locally owned enterprises; and matters related to loans and grants. The $\mathrm{MOHA}$ coordinates and regulates regional budgets (under MOHA Regulation No. 37 of 2014 and applicable amendments related to budget preparation guidelines), while also providing guidance in monitoring their implementation. Proposals for regional programs must be submitted through the relevant line ministry and included in the state budget. The MOHA guides the regions through this process, especially when regional borrowing is involved. 
Figure 9: Fund Allocation from Central to Local Government

\section{Central Government Local Government MONEY FOLLOWS FUNCTION AND CAPACITY}

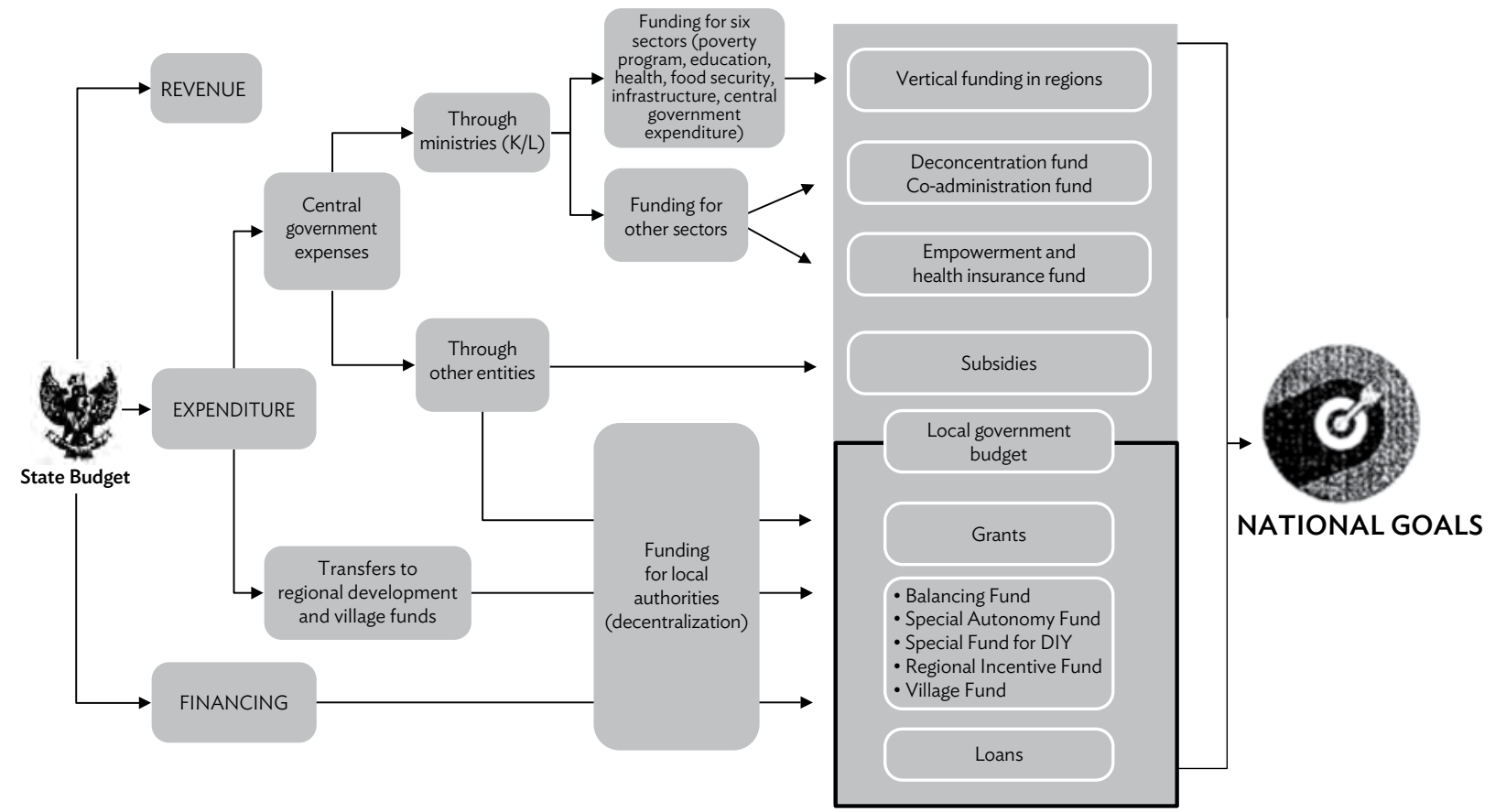

DIY = Daerah Istimewa Yogyakarta (Yogyakarta Special Administrative Region); K/L = Kementerian dan Lembaga (ministry/agency). Source: Department of Budget, Ministry of Finance (adapted).

Budget preparation in provinces, districts, and cities begins around May or June. As firm and reliable information about transfers to individual SNGs is established only after APBN approval in October, when the APBN is approved, budgets are based on allocations made in previous years. ${ }^{17} \mathrm{~A}$ summary of the regional budget calendar is shown in Table 1.

Some SNGs do not prepare their budgets on time. The noncompliance is due to SNG difficulties in forecasting their own revenue, local elections, and poor coordination between the Regional Representative Councils and the districts or cities, and not to delayed notification of individual allocations to SNGs. ${ }^{18}$

World Bank. 2012. Indonesia: Public Expenditure and Financial Accountability. Washington, DC.

World Bank. 2012. Indonesia: Public Expenditure and Financial Accountability. Washington, DC. 


\section{Table 1: Regional Budget Calendar}

\begin{tabular}{|c|c|}
\hline Process & Timeline \\
\hline $\begin{array}{l}\text { The SNG conveys to the Legislative Council its regional budget policy } \\
\text { for the next fiscal year, in line with the SNG's work plan, to guide the } \\
\text { drafting of the regional budget }\end{array}$ & Mid-June \\
\hline $\begin{array}{l}\text { The Legislative Council discusses the regional budget policy proposed } \\
\text { by the SNG during preliminary talks on the draft regional budget for the } \\
\text { next fiscal year }\end{array}$ & June-July \\
\hline $\begin{array}{l}\text { The SNG and the Legislative Council discuss budget priorities and } \\
\text { ceilings based on the regional budget policy they have agreed on, to } \\
\text { serve as reference points for the regional work units }\end{array}$ & July-August \\
\hline $\begin{array}{l}\text { The regional work units prepare their work plans and budgets, together } \\
\text { with expenditure estimates, for the next fiscal year }\end{array}$ & August \\
\hline $\begin{array}{l}\text { Submit the work plan and the budget to the legislative council to be } \\
\text { discussed in the preliminary talks of the draft regional budget }\end{array}$ & September \\
\hline $\begin{array}{l}\text { The SNG submits the results of the discussions on the work plans } \\
\text { and budgets to the regional financial management officer, to be taken } \\
\text { into account in the preparation of the draft regulation on the regional } \\
\text { budget }\end{array}$ & September \\
\hline $\begin{array}{l}\text { The SNG submits the draft regulation on the regional budget, along } \\
\text { with explanations and supporting documents, to the Legislative } \\
\text { Council }\end{array}$ & First week of October \\
\hline $\begin{array}{l}\text { The Legislative Council discusses the draft regulation on the regional } \\
\text { budget }\end{array}$ & October-November \\
\hline $\begin{array}{l}\text { The Legislative Council proposes changes in the revenue and } \\
\text { expenditure amounts stated in the draft regulation on the regional } \\
\text { budget }\end{array}$ & October-November \\
\hline $\begin{array}{l}\text { The Legislative Council decides on the draft regulation on the regional } \\
\text { budget }\end{array}$ & November \\
\hline \multicolumn{2}{|l|}{ SNG = subnational government. } \\
\hline Sources: Au & \\
\hline
\end{tabular}

\section{E. Budgetary Channels}

\section{Budgeting for Foreign Funding Sources}

Foreign-funded projects are approved by BAPPENAS. Provisions are made for these projects in state and regional budgets. Project loans do not have to be approved individually by Parliament; these are approved in aggregate as the net value of loans through the budgetary process. Expenditures for new projects are included in the budget only if the projects are in the Blue Book and discussions have progressed toward the projects' inclusion in the Green Book (Figure 10). If project start-up within the coming year is still uncertain, a small amount should be budgeted for the project to speed up its launch. For projects that have progressed to the Green Book stage, the proposed expenditure is included in the work and budget plans of the relevant institution. However, a breakdown of 
foreign funding by project or program can be obtained only at the DIPA stage, as the budget does not include a breakdown of expenditure by activity.

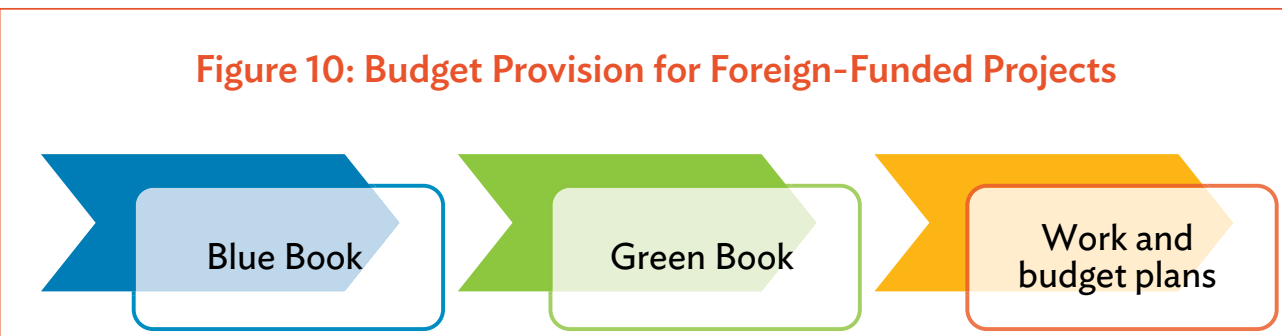

Source: Author's compilation, based on discussions with government stakeholders.

Government Regulation No. 10 of 2011 on the Procedures for the Procurement of Foreign Loans and Grants requires ministries and institutions to include foreign loans in their work and budget plans. Under Article 22 of the regulation, the MOF is also tasked with preparing a financing plan for foreign loans that are onlent to SNGs and SOEs or ongranted to SNGs.

Foreign-funded projects carried out by central government agencies are included in the budget of the relevant ministry or agency of the central government. If the project executing agency is a regional authority, and a subgranting mechanism is applied to transfer donor funding to the SNG, the funds are included in the MOF budget and fund delivery to the SNG is handled by the director general of fiscal balance. Also, if donor funds are onlent to an SNG for project implementation, the funds are captured in the MOF budget and fund delivery is handled by the director of the Investment Management System (SMI).

SOE projects may be funded by foreign loans onlent by the central government or lent directly to the SOE with a government guarantee. In the former case, the funds are captured in the MOF budget and regulated by the SMI director; in the latter case, the funds are considered off-budget items or contingent liabilities, and are handled by the director general of debt management. These off-budget items are disclosed only in notes to government financial statements. Nonperforming loans to around 20 SOEs are currently being restructured. The government is responsible for repaying the direct borrowings of SOEs in default, although there is no budgetary allocation for that purpose. The government lacks an active mechanism for managing these contingent obligations and is considering introducing a mechanism to cover the financial risk arising from guarantees given to SOEs.

Under Law No. 33 of 2004 on Fiscal Balance between the Central and Regional Governments, the central government may lend externally borrowed funds to an SNG only through an onlending agreement with that SNG. Government Regulation No. 10 of 2011 provides for the ongranting of foreign-sourced funds to an SNG through a subsidiary agreement signed by the finance minister or other authorized official of the central government and the head of the recipient local government (governor, regent, or mayor). 


\section{Relationship between Disbursement and Budget Plans}

Under MOF Regulation No. 84 of 2015 on Procedures for the Withdrawal of Foreign Loans and Grants, foreign loans must be disbursed in accordance with the budget allocation in the DIPA. The DIPA sets a disbursement limit for each spending unit, broken down by function or subfunction, program, activity, outcome, and output classification. It also includes a cash flow plan for the projected monthly inflows and outflows of each spending unit..$^{19}$ If the required withdrawal exceeds the budget allocation in the DIPA, the ministry or institution must propose a revision of the DIPA in accordance with the legislation.

MOF Regulation No. 192 of 2009 on Cash Forecasting requires spending units to submit their cash withdrawal plans yearly to the local Treasury Service Office (KPPN) to update the disbursement plans included in their DIPA. Spending units must submit their updated daily, weekly, and monthly cash disbursement plans on time. They must update their daily disbursement forecast, for a 1-week period, at least 1 business day before the period; their weekly forecast, for a 2-month period, at least 2 business days before the period; and their monthly forecast, for a 1-year period, at least 3 business days before the period. The Work-Units Forecasting Application (AFS) supports the preparation and submission of this information by the project owners. ${ }^{20}$ At present, however, only projects with large disbursements use the AFS. The government intends to bring all projects into the AFS system in the near future.

The disbursement plans are also linked to the Debt Management and Financial Analysis System (DMFAS). For now, only the most current disbursement projections are kept in the system, to allow performance assessment. But a new system currently being developed will keep track of projections and thus improve the analysis of actual versus projected disbursements. Forecasting is a challenge for ministry staff, given the wide range of projects and the possible involvement of more than one donor for a project. The reliability of forecasts could be an issue. Capacity building of ministry staff would improve cash forecasting for different types of projects.

Each quarter, the executing agencies must also report on the progress of their projects to the MOF Directorate of Evaluation, Accounting, and Settlement (EAS) and to BAPPENAS. The stakeholders hold tripartite meetings to discuss project performance and to make sure that adequate funds are allocated for planned disbursements.

\section{Accounting for Foreign Funds}

The MOF Directorate of Accounting and Financial Reporting prepares the financial reports of the central government (LKPP), the state budget (APBN) accountability reports. These reports should comprise at least the state budget realization report, the balance sheet, the cash flow statement, and the notes to the financial statements of state enterprises and other entities. Under Government Regulation No. 10 of 2011, the MOF prepares the accountability report on the administration of foreign loans and grants as part of the accountability process for APBN implementation. Foreign fund disbursements through 
the state budget are captured in the Financial Management Information System (SPAN), which is used in compiling debt management reports. Loan and grant monitoring reports, on the other hand, including absorption realization and other financial aspects, are based on the DMFAS.

Project unit requests for payment from the MOF indicate the budget code (identifying the function, subfunction, unit, program, activity, and type of expenditure). Project management units (PMUs) receive each week from the MOF a record of project disbursements to be cross-checked against PIU records. All PIUs have view access to SPAN and can go over project payments. The MOF sends financial monitoring reports to the PMUs every quarter for reconciliation with project accounts.

\section{F. Internal Controls}

\section{Expenditure Controls}

Government expenditure must be provided for in the budget and must not exceed the expenditure ceiling imposed by law on each spending unit through the DIPA. Commitments are limited to approved allocations and governed by the availability of cash. By issuing Government Regulation No. 60 of 2008 on the Government Internal Control System, the government adopted the internal control framework developed by the Committee of Sponsoring Organizations of the Treadway Commission (COSO). ${ }^{21}$

The President as the head of government holds the power of state financial management. The MOF as the fiscal manager is responsible for the overall administration of public finance. Expenditure controls are maintained at different levels of government by the responsible financial officers and include control mechanisms such as segregation of duties, authorization of approvals, and restrictions on access to resources and information. The introduction of SPAN by the MOF for financial management at the ministry or agency level has also strengthened commitment controls. In addition, expenditure must pass internal and external audits, as well as Parliamentary scrutiny. With regard to foreign funding, financing agreements and compliance with donor financing mechanisms introduce another level of control.

\section{Internal Audit}

Government Regulation No. 60 of 2008 and Presidential Instruction (Inpres) No. 4 of 2010 give responsibility for the effective implementation of the internal control system within an organization to the minister or the head of the institution, the governor, the regent, or the mayor. Four types of institutions are responsible for implementing the government internal audit function: (i) the Financial and Development Supervisory Board (BPKP); (ii) the inspector general; (iii) the provincial inspectorate; and (iv) the district or city inspectorate. BPKP supervision of state financial accountability includes cross-sectoral activities, state treasury activities performed at the request of the minister of finance as the general treasurer, and other activities carried out at the President's request. The inspector

21 World Bank. 2012. Indonesia: Public Expenditure and Financial Accountability. Washington, DC. 
general supervises the activities of ministries and agencies funded through the APBN; the provincial inspectorate, the activities of regional spending units funded through the provincial APBD; and the district or city inspectorate, the activities of district or city spending units funded through the district or city APBN.

The BPKP conducts over 14,000 audits yearly, including regional audits, and follows standards consistent with the International Standards for the Professional Practice of Internal Auditing, developed by the Institute of Internal Auditors (IIA). The BPKP also reviews the unaudited financial statements of ministries or agencies before these are submitted to the BPK for external audit. ${ }^{22}$ In addition to internal audit and supervision, the BPKP likewise assists the various ministries, agencies, and SNGs in implementing Government Regulation No. 60 of 2008 by issuing technical guidelines for the implementation of government internal control systems and by training their internal audit staff. Presidential Decree No. 192 of 2014 on the BPKP details, among others, the duties, functions, and operating procedures of the BPKP.

Internal audits of foreign-funded projects are conducted by the BPKP and the inspector general, as well as by the provincial, district, or city inspectorate. The responsibilities are generally divided between the BPKP and other internal auditors with no overlap in their areas of focus. As a rule, internal audits of projects are done as part of the internal audit of the government institutions that planned the projects or are implementing them. Internal audits generally take place once or twice a year, or as needed, and determine compliance with expenditure controls and performance standards. The inspector general's audit report is submitted to the minister and possibly also to the head of the PMU on request. The PMU head will take up issues highlighted by the report with the relevant units.

A recent $A D B$ paper on Indonesia and the World Bank's public expenditure and financial accountability (PEFA) assessment of 2012 noted the need to strengthen the quality of audit by inspectors general in line ministries and SNG inspectorates, particularly in the area of risk-based audit. Internal audits mostly center on verifying the accuracy of transactions and compliance with standards. While risk-based audits are practiced in some ministries, internal control systems are rarely reviewed. The reports mentioned the ongoing design of the Accountability Management Information System (SIMA) by the government in an effort to improve internal audit. However, the implementation of risk-based audit is hampered by weak coordination among regional agencies, the absence of a uniform audit planning framework, the lack of trained auditors, and the massive scale of local government in Indonesia. The reports identified the need to improve the audit skills of auditors and institutional capacity through formal education and a professional certification program. ${ }^{23}$

The BPKP is the only organization tasked with following up on internal audit recommendations. The BPKP sends a letter of recommendation to the ministries every quarter. If it receives no response, the BPKP informs the relevant minister of the need for action. Government internal control systems in Indonesia could stand improvement.

Information obtained during a meeting with the BPK on 25 April 2016

ADB. 2015. Summary of Indonesia's Public Sector Management Sector Assessment. Papers on Indonesia. No. 11 Manila; World Bank. 2012. Indonesia: Public Expenditure and Financial Accountability. Washington, DC.. 


\section{Reporting and Monitoring}

The PMUs must report to their ministries or agencies. The PMUs or executing agencies are also collectively responsible to the government and donors. Major reporting responsibilities include the following:

(i) The executing or implementing agency prepares

(a) an annual disbursement plan, for submission to the MOF Directorate of Loans and Grants;

(b) daily, weekly, and monthly cash requirement updates, for submission to the Treasury through the AFS; and

(c) quarterly project progress reports to the MOF and BAPPENAS, indicating funds absorption, the physical implementation of activities, progress made in the procurement of goods and services, issues and constraints faced, and the necessary follow-up steps. The quarterly reports are due on 31 March, 30 June, 30 September, and 31 December.

(ii) The PMUs prepare annual financial statements, submit these to the relevant ministry or institute and to the auditor general, and forward the audited financial statements to the donor.

Foreign-funded projects are monitored at different levels. The implementing ministry or agency, together with the Directorate General of Budget, monitors projects by keeping monitoring records for each foreign loan and grant, capturing general loan details, as well as the total ceiling, annual ceilings, annual realization, and unexpended funds. The EAS and BAPPENAS are responsible for monitoring and evaluating foreign-funded projects. These projects are also subject to internal and external audits to ensure that they are implemented according to the agreed terms and conditions of the loan or grant agreements, and also to comply with government rules and regulations.

Responsibility for monitoring and evaluation rests with the MOF where the financial performance of projects is concerned, and with BAPPENAS when it comes to implementation performance. The MOF uses information obtained from the DMFAS, quarterly reports, and other relevant documents, as well as from meetings and site visits. BAPPENAS monitors implementation performance through meetings, reports on the implementation of activities, and site visits. Quarterly meetings held to monitor project performance and coordinated by BAPPENAS bring together the project proponent and implementing agencies, the MOF, and other relevant agencies. If the loan is channeled to an SNG, the MOHA may also be among the participants.

The MOF publishes a quarterly report on foreign loan and grant absorption and other financial aspects, while BAPPENAS publishes a quarterly report on the implementation performance of activities financed by foreign loans or grants. 


\section{Onlending Arrangements}

The Government of Indonesia obtains foreign loans to finance state budget deficits;

administer debt portfolios; or finance the priority activities of ministries or agencies, SNGs, and SOEs. Grants received support national development programs or natural disaster management and humanitarian assistance programs. ${ }^{24}$ As shown in Figure 11, Government Regulation No. 10 of 2011 (Article 3) authorizes the finance minister to onlend the foreign funds received to SNGs and SOEs, or to subgrant the funds to SNGs.

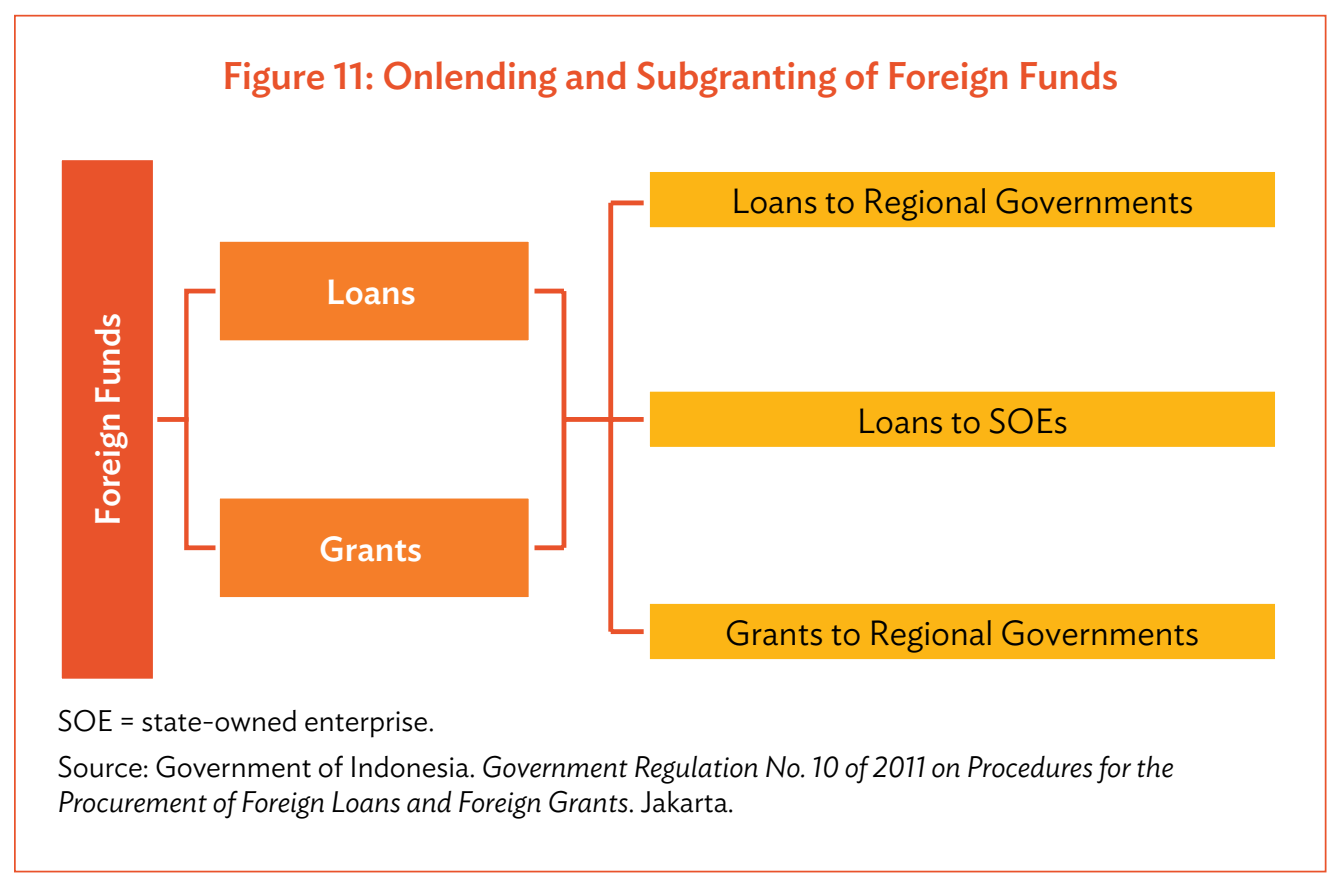

Onlent or subgranted foreign loans are administered through subsidiary loan agreements signed by the finance minister and the SNG governor, regent or mayor, or the SOE board of directors. Under Government Regulation No. 10 of 2011, these subsidiary agreements (known as "foreign loan channeling agreements" for onlending and "foreign loan subgrant agreements" for subgranting) must include at least details of the amount, purpose, and terms and conditions of the main loan agreement. The conditions of the loan or grant

Government of Indonesia. Government Regulation No. 10 of 2011 on Procedures for the Procurement of Foreign Loans and Foreign Grants. Jakarta. 
agreement are discussed and agreed on in the tripartite meeting attended by the MOF, BAPPENAS, and the recipient line ministry, SNG, or SOE.

\section{A. For Ministries and Agencies}

Foreign funds for ministries and agencies under the central government are always allocated through the state budget under the respective budget heads, and approved by Parliament. These entities are entitled to withdraw funds from the SGTA against those budget allocations. Although the central government borrows in foreign currency, the allocations to ministries and agencies are made in local currency.

\section{B. For Subnational Governments}

According to Law No. 33 of 2004 (Articles 44 and 56) on Fiscal Balance between the Central and Regional Governments, all foreign loans and grants to SNGs should be made through the central government. The central government, through a subsidiary grant or loan agreement, engages in subgranting, and full or partial onlending, to SNGs. Subgrants are always made in local currency and budgeted under the relevant line ministry. Foreign funds onlent to SNGs are in local or foreign currency, and are provided for under the MOF budget head. These funds are also included in the regional budget and withdrawn by project owners against their local budget allocations. The repayment of onlent funds is closely monitored by the Directorate Investment Management System (SMI) of the MOF.

\section{For State-Owned Enterprises}

The central government onlends to SOEs through subsidiary loan agreements, in either local or foreign currency. Even though legal provisions for subgranting foreign funds to SOEs are in place (Article 24 of Law No. 17 of 2003 on State Finance), the government has not yet implemented these. Provisions are made under the Ministry of Finance budget head for the SOEs to use the foreign funds. It is the responsibility of the Directorate of SMI to see to it that the loans are repaid together with the applicable interest. 


\section{Foreign Exchange and Interest Rate Risks}

E or subgrants to SNGs, the central government bears the foreign exchange and interest rate risks. In the case of onlending, those risks are passed on to the subborrower. Generally, the government favors sublending in the original loan currency. If the subloan is in local currency, the government factors in the exchange rate risk by applying a margin to the interest rate charged to the subborrower.

Subloan repayment as specified in the subsidiary loan agreement is the responsibility of the subborrower. According to Government Regulation No. 10 of 2011, all repayments are to be made through the SGTA or another account established for this purpose by the minister of finance. Payment schedules for the subloan agreements are captured in the DMFAS, and the SMI uses its Subsidiary Loan Management Information System to send reminders and follow up payment. If repayment by an SNG is delayed, this regulation authorizes the finance minister to make deductions from the General Allocation Fund (DAU) or Revenue-Sharing Fund (DBH) applicable to the SNG. Late payment of subloans or interest results in penalties for the SOEs, which also face other sanctions laid down in the subsidiary loan agreement. 


\title{
Funds Flow Arrangements
}

\begin{abstract}
$\triangle \mathrm{s}$ a prerequisite for withdrawal from a loan or grant account, the MOF submits evidence of authority of the persons who will sign the withdrawal applications, or deliver the withdrawal applications electronically in the client portal for disbursements system to ADB. ADB funds flow arrangements in Indonesia fall under one of four categories. These categories, with details of funds flow, recording in government accounts, fund transfers between government agencies, and required documentation, are discussed below. ${ }^{25}$
\end{abstract}

\section{A. Advance Fund Procedure}

An advance account in foreign currency (special account) is maintained at Bank Indonesia for each foreign loan agreement. These accounts are kept separate from the State General Treasury Account (SGTA) and are not swept daily to the SGTA on a daily basis. Expenditures of foreign-funded activities are met through the SGTA and an equivalent amount is transferred from the special account to the SGTA on the same day.

Under the advance fund procedure, ADB remits to the special account an advance representing $A D B$ 's share for eligible project expenditures and requests for replenishment from the executing agency or the PMU.

\section{Funds Flow}

The advance fund procedure comprises the steps listed below and represented graphically in Figure 12.

\section{Receipt of Advance from $A D B$}

(i) The executing agency or the PMU submits a withdrawal application based on the forecast expenditures for the next 6 months, along with the supporting documents (Box 1), to the Directorate of State Cash Management (PKN).

(ii) The PKN authorizes the request and submits the withdrawal application to the Indonesia Resident Mission Disbursement Unit (IRM-DU). A copy is sent to the EAS for reference purposes. 
Figure 12: Advance Fund Procedure



ADB = Asian Development Bank; DJPPR = Direktorat Jenderal Pengelolaan Pembiayaan dan Risiko (Directorate General of Budget Financing and Risk Management); EAS = Direktorat Evaluasi, Akuntansi dan Setelmen (Directorate of Evaluation, Accounting, and Settlement); IRM = Indonesia Resident Mission; KPPN = Kantor Pelayanan Perbendaharaan Negara (Treasury Service Office); $\mathrm{PIU}=$ project implementation unit; $\mathrm{PMU}=$ project management unit; $\mathrm{PO}=$ payment order; SP2D = Surat Perintah Pencairan Dana (payment voucher); SPM = Surat Perintah Membayar (payment order); WA = withdrawal application.

Source: Author's compilation, based on discussions with government stakeholders. 
(iii) The IRM verifies the received documents, enters the details into ADB's Loan Financial Information System (LFIS), and generates a disbursement voucher if the withdrawal application is in order.

(iv) After verification by the IRM-DU, the Loan Administration Division of the Controller's Department of ADB (CTLA) authorizes the withdrawal application.

(v) After receiving the CTLA's authorization, the ADB Treasury Department remits funds to the special account at Bank Indonesia.

\section{Payment to Contractor, Supplier, Consultant}

(i) The contractor, the supplier, or the consultant submits an invoice to the executing agency or the PMU.

(ii) The executing agency authorizes the payment order (SPM) issued by the PMU after checking the invoice details, and submits the SPM to the KPPN.

(iii) The KPPN approves the SPM and issues a payment voucher (SP2D) through SPAN instructing the operational bank of the Treasury to make a direct payment. A sum equivalent to the amount to be paid will be transferred from the special account to the SGTA on the same day.

(iv) Periodically, a list or reports could be generated through SPAN by relevant parties (PKN, KPPN, executing agency, etc.) to show the number of SP2Ds that have been issued.

\section{Liquidation and Replenishment from $A D B$}

(i) The executing agency or the PMU submits a withdrawal application, along with the supporting documents (see Box 1 ), to the PKN.

(ii) The PKN authorizes the request and submits the withdrawal application to the IRM-DU. A copy is sent to EAS for reference purposes.

(iii) The IRM-DU verifies the received documents, enters the details into ADB's LFIS, and generates a disbursement voucher if the withdrawal application is in order.

(iv) After verification by the IRM-DU, the CTLA authorizes the withdrawal application to replenish the special account.

(v) After receiving the CTLA's authorization, the ADB Treasury Department remits funds to the special account.

\section{Recording in Government Accounts}

\section{Initial Advance from $A D B$}

The EAS verifies the disbursement details obtained by logging into the LFIS and compares these with the withdrawal application details. The EAS issues a loan or grant withdrawal record order (SP4-HLN) to the PKN. The PKN records the liability for the funds received in the special account.

\section{Payment from Advance Account}

All payments made directly to the contractor, supplier, or consultant are recorded by the PKN as expenses in the accounts. Bank Indonesia issues a credit or debit advice, along 
with the weekly current account report on the special account, to the PKN for accounting purposes.

\section{Liquidation and Replenishment}

The EAS verifies the notice of disbursement received from ADB by comparing it with the withdrawal application details. The EAS issues a loan or grant withdrawal record order (SP4-HLN) to the PKN. The PKN reconciles the cash inflows in the special account and records the liability.

\section{Documentary and Approval Requirements}

The withdrawal application must be signed by the authorized signatories for the project.

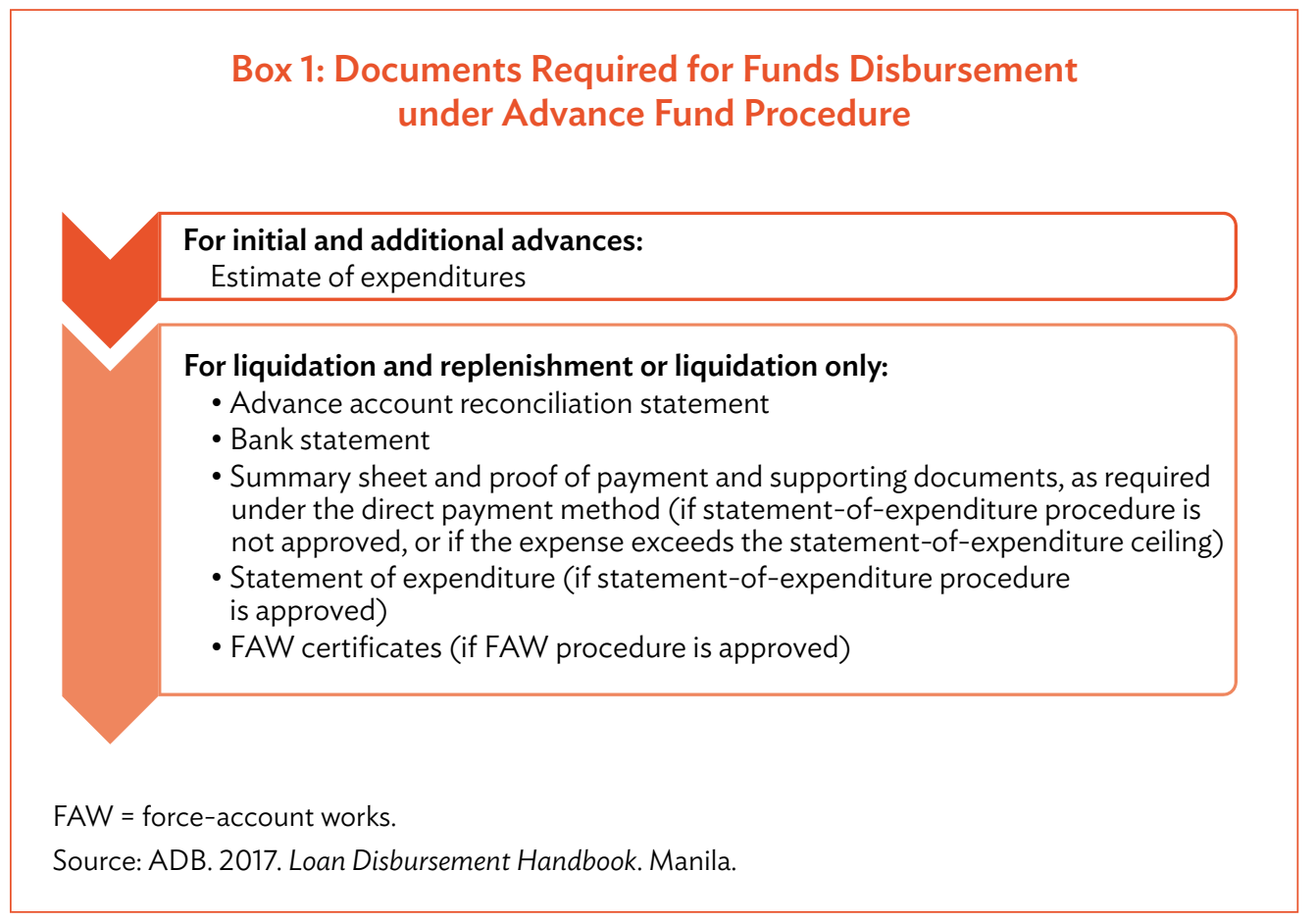

\section{B. Direct Payment Procedure}

Funds flow under this method occurs only between $A D B$ and the contractor, the supplier, or the consultant. The Special Treasury Service Office (Special KPPN) requests ADB to transfer funds for the expenses incurred by the executing agency or the PMU directly to the contractor, the supplier, or the consultant through withdrawal from the loan or grant account.

\section{Funds Flow}

The steps involved in direct payment are as follows (see Figure 13). 
Figure 13: Direct Payment Procedure

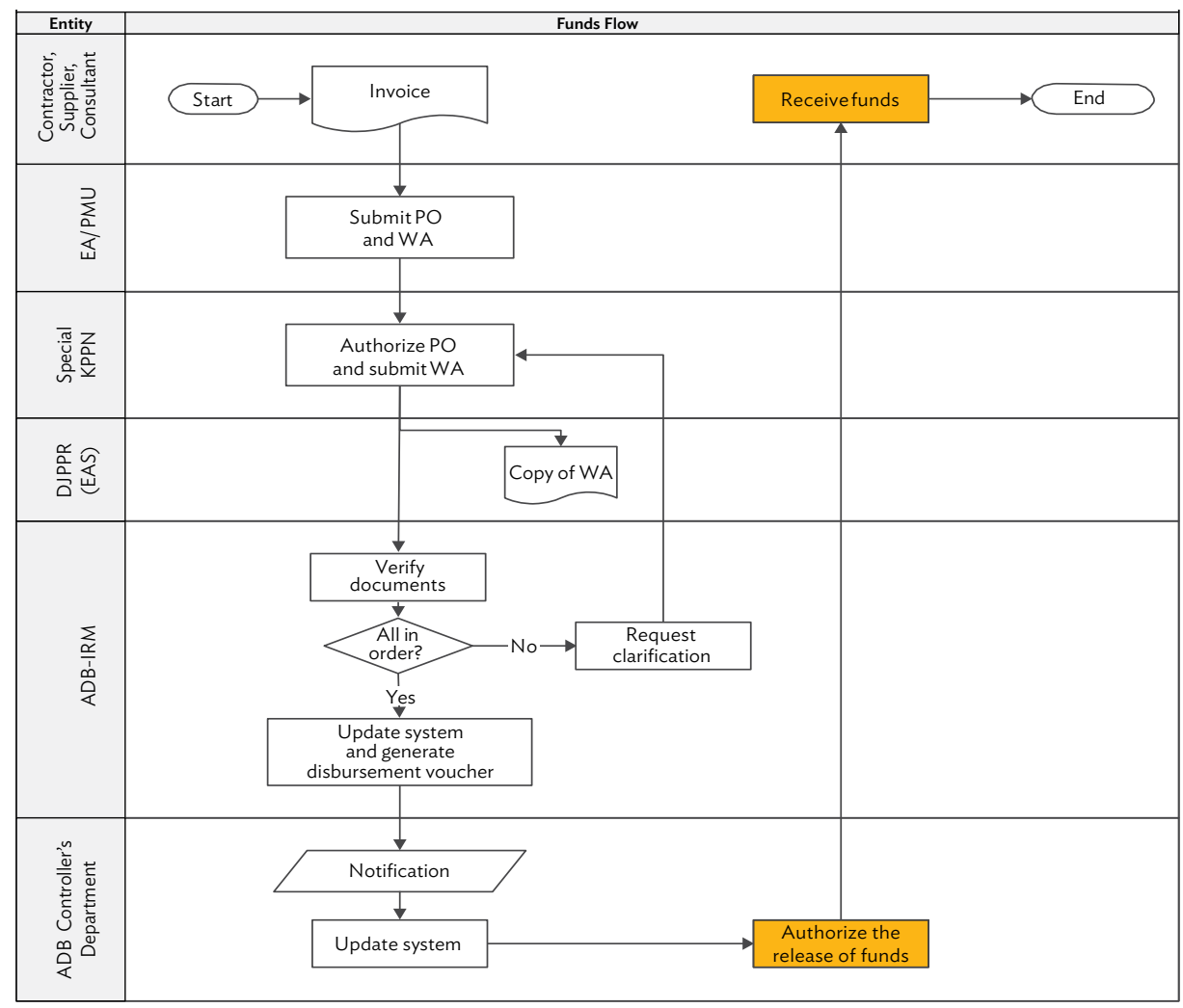

$\mathrm{ADB}=$ Asian Development Bank; DJPPR = Direktorat Jenderal Pengelolaan Pembiayaan dan Risiko (Directorate General of Budget Financing and Risk Management); EAS = Direktorat Evaluasi, Akuntansi dan Setelmen (Directorate of Evaluation, Accounting, and Settlement); IRM = Indonesia Resident Mission; KPPN = Kantor Pelayanan Perbendaharaan Negara (Treasury Service Office); $\mathrm{PIU}=$ project implementation unit; $\mathrm{PMU}=$ project management unit; $\mathrm{PO}=$ payment order; SPM = Surat Perintah Membayar (payment order); WA = withdrawal application.

Source: Author's compilation, based on discussions with government stakeholders.

(i) The executing agency or the PMU receives an invoice for the expense from the contractor, the supplier, or the consultant.

(ii) The executing agency or the PMU authorizes the SPM after checking the invoice details and submits this, along with the withdrawal application, to the Special KPPN.

(iii) The Special KPPN verifies the details and submits the withdrawal application with supporting documents (see Box 2) to the Indonesia Resident Mission Disbursement Unit (IRM-DU). A copy is sent to the EAS for reference purposes.

(iv) The IRM-DU verifies the received documents, enters the details into ADB's LFIS, and generates a disbursement voucher if the withdrawal application is in order.

(v) After verification by the IRM-DU, the CTLA authorizes the withdrawal application.

(vi) After receiving the CTLA's authorization, the ADB Treasury Department remits funds directly to the contractor's, the supplier's, or the consultant's account. 


\section{Recording in the Government Accounts}

The EAS verifies the disbursement details obtained by logging into the LFIS and comparing these with the withdrawal application details, and issues a loan or grant withdrawal record order (SP4-HLN) to the Special KPPN. After verifying the documents, the Special KPPN issues a record or endorsement order (SP3) and records the liability and expenditure in the accounts.

\section{Documentary and Approval Requirements}

The withdrawal application must be signed by the authorized signatories for the project.

Box 2: Documents Required for Funds Disbursement
under Direct Payment Method
$\begin{aligned} & \text { Invoice of contractor, supplier, or consultant } \\ & \text { Interim payment related to civil works) }\end{aligned}$
$\begin{aligned} & \text { Unconditional bank guarantee (where payment of retention money is due past the } \\ & \text { loan closing date and no extension of the closing date is intended) }\end{aligned}$
Source: ADB. 2017. Loan Disbursement Handbook. Manila.

\section{Commitment Procedure}

Like direct payment, this method gives rise to funds flows that occur only between ADB and the supplier. The executing agency or the PMU obtains the services of the supplier by means of a letter of credit issued to the supplier's bank. The payment to the supplier's bank under the letter of credit is funded through an irrevocable commitment letter issued by ADB to the negotiating bank (the supplier's bank).

\section{Funds Flow}

The steps involved in the commitment procedure are as follows (see Figure 14).

\section{Opening of Letter of Credit}

(i) The executing agency or the PMU submits a request for a letter of credit with power of attorney (LC-POA) to the Special KPPN. 


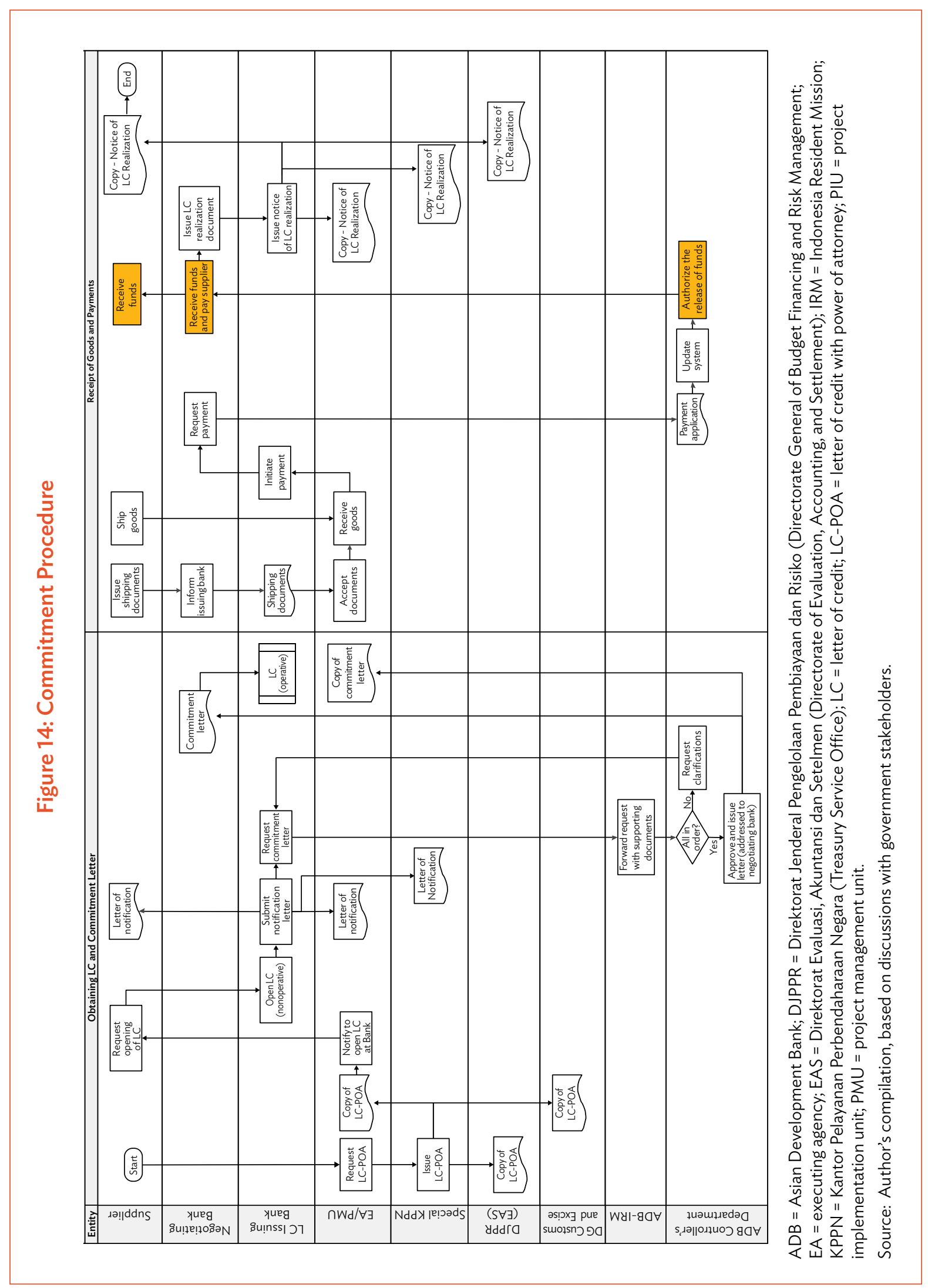


(ii) The Special KPPN verifies the supporting documents and issues the LC-POA to the issuing bank. A copy is given to the EAS, the director general of customs and excise, and the executing agency or the PMU. For each loan agreement, an LC-POA is issued only once covering the entire value of the contracts for procurement to be made through a letter of credit.

(iii) After being notified by the executing agency or the PMU, the supplier issues a request for the opening of a letter of credit to the issuing bank.

(iv) Taking into account the LC-POA and the request from the supplier for the opening of a letter of credit, the issuing bank opens a letter of credit. The letter of credit will be nonoperative until ADB issues a commitment letter. The issuing bank sends a letter to the supplier, the executing agency, or the PMU, and the Special KPPN, notifying them of the opening of the letter of credit. The details of the letter of credit are recorded in the letter of credit monitoring card by the Special KPPN for monitoring purposes.

\section{Request for Commitment Letter from $A D B$}

(i) The issuing bank submits an application for a commitment letter, along with the supporting documents (see Box 3), to ADB's Indonesia Resident Mission, which forwards the request to the Controller's Department of ADB.

(ii) The ADB Controller's Department issues an irrevocable commitment letter to the negotiating bank if the documents are in order. The letter of credit becomes operative only after ADB issues the commitment letter.

\section{Receipt of Goods and Confirmation by Executing Agency or PMU}

(i) The supplier sends the shipping documents to the issuing bank through the negotiating bank.

(ii) The executing agency or the PMU conveys its acceptance of the shipping documents to the issuing bank after verification.

(iii) The executing agency or the PMU receives the shipped goods from the supplier and accepts these after inspection.

\section{Payment to Supplier}

(i) The issuing bank informs the negotiating bank of the required payments.

(ii) The negotiating bank requests payment from ADB (for the payment made or due to be made to the supplier according to the terms stated in the letter of credit) through the Society for Worldwide Interbank Financial Telecommunication (SWIFT).

(iii) After receiving the SWIFT notification, the CTLA prepares a disbursement voucher and authorizes the request of the negotiating bank.

(iv) After receiving authorization from the CTLA, the ADB Treasury Department remits funds to the negotiating bank.

(v) The negotiating bank pays the supplier and issues a letter of credit realization document. The issuing bank then notifies the supplier of the issuance of this document, and sends a copy to the executing agency or the PMU, the Special KPPN, and the EAS. 


\section{Recording in the Government Accounts}

The EAS issues a loan or grant withdrawal record order (SP4-HLN) to the Special KPPN after verifying the disbursement details obtained by logging into the LFIS and comparing these with the details in the notice of letter of credit realization and in the letter of credit monitoring card. The Special KPPN then issues an acknowledgment of the record or endorsement order (SP3) and enters the liability and expenditure into the accounts.

\section{Documentary and Approval Requirements}

The withdrawal application must be signed by the authorized signatories for the project.

\section{Reimbursement Procedure}

Reimbursement requires bridge financing of the ADB portion of the expenditure by the $P M U$, using its own resources. $A D B$ reimburses the expenditure incurred and paid from the loan at the request of the executing agency or the PMU. The government does not use this statement-of-expenditure method (for small transactions). The funds flow arrangement discussed below is for projects implemented by SNGs or SOEs.

\section{Box 3: Documents Required for Issuance of Commitment Letter}

A contract or confirmed purchase order, if not submitted earlier

Copy of the letter of credit against which ADB commitment letter is requested

$\mathrm{ADB}=$ Asian Development Bank.

Source: ADB. 2015. Loan Disbursement Handbook. Manila (adapted).

\section{Funds Flow}

The steps involved in the reimbursement method are as follows (see Figure 15).

\section{Payment for Services Received}

(i) The contractor, the supplier, or the consultant submits the invoice to the executing agency or the PMU.

(ii) The executing agency or the PMU verifies the details and pays the contractor, the supplier, or the consultant from its own funds. 
Figure 15: Reimbursement Procedure



ADB = Asian Development Bank; DJPPR = Direktorat Jenderal Pengelolaan Pembiayaan dan Risiko (Directorate General of Budget Financing and Risk Management); EA = executing agency; EAS = Direktorat Evaluasi, Akuntansi dan Setelmen (Directorate of Evaluation, Accounting, and Settlement); IRM = Indonesia Resident Mission; KPPN = Kantor Pelayanan Perbendaharaan Negara (Treasury Service Office); MOF = Ministry of Finance; PIU = project implementation unit; PMU = project management unit; $\mathrm{SMI}=$ Direktorat Sistem Manajemen Investasi (Directorate of Investment Management System); SNG = subnational government; $\mathrm{SOE}$ = state-owned enterprise; $\mathrm{WA}=$ withdrawal application.

Source: Author's compilation, based on discussions with government stakeholders. 


\section{Reimbursement from $A D B$}

(i) The executing agency or the PMU submits a withdrawal application to the Directorate General of Fiscal Balance (for SNG projects) or the SMI (for SOE projects).

(ii) The Directorate of Fiscal Balance or the SMI approves the withdrawal application and forwards it to the Special KPPN.

(iii) The Special KPPN submits the withdrawal application to the Disbursement Unit of ADB's Indonesia Resident Mission (IRM-DU), together with the supporting documents (see Box 4). A copy of the application is sent to the EAS for reference purposes.

(iv) The IRM-DU verifies the received documents, enters the details into ADB's LFIS, and generates a disbursement voucher if the withdrawal application is in order.

(v) After verification by the IRM-DU, the CTLA approves the withdrawal application.

(vi) After receiving the CTLA's authorization, the ADB Treasury Department remits funds to the account of the executing agency or the PMU.

\section{Recording in the Government Accounts}

The EAS issues the loan or grant withdrawal record order (SP4-HLN) to the Special KPPN after verifying the disbursement details obtained by logging into the LFIS and comparing these with the details in the withdrawal application. The Special KPPN then issues an SP3 and enters the expenditure and liability into the accounts.

\section{Documentary and Approval Requirements}

The withdrawal application must be signed by the authorized signatories for the project.

\section{Box 4: Documents Required for Funds Disbursement under Reimbursement Procedure}

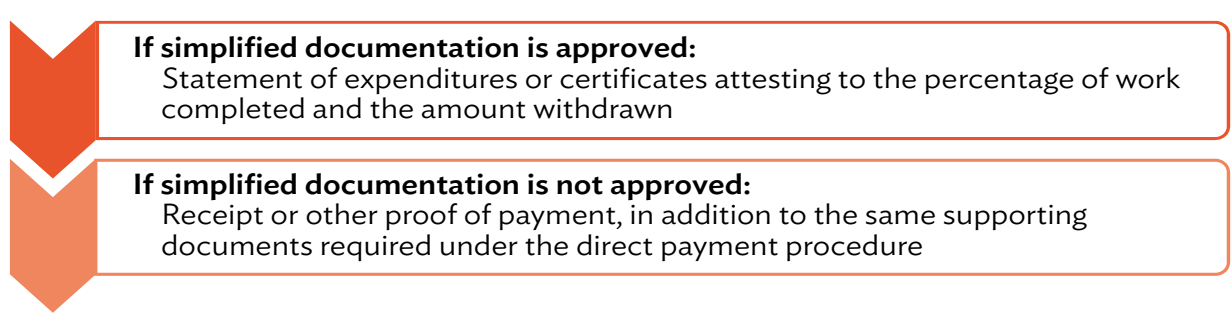

Source: ADB. 2017. Loan Disbursement Handbook. Manila (adapted). 


\section{Accounting and Reporting}

\section{A. Accounting Standards}

\section{Public and Private Companies}

The Indonesian Institute of Accountants (IAI) is the professional accounting body, although this is not explicitly stated in the law. The Financial Accounting Standards Board (DSAK) under the IAI sets accounting standards for the country.

The Indonesian Company Law No. 40 of 2007 requires corporations to meet the accounting standards set by a government-recognized professional accounting organization when preparing their annual financial statements. In addition, as specified in Law No. 8 of 1995 on the Capital Market, the Capital Markets and Financial Institutions Supervisory Board (BAPEPAM-LK) exacts compliance with Indonesian Financial Accounting Standards (PSAK), issued by DSAK, among listed companies, public as well as private.

Indonesia, taking the gradual convergence approach, has made significant progress toward PSAK compliance with International Financial Reporting Standards (IFRS). But it has yet to announce its timetable for full adoption. Although Indonesia is committed to minimizing the dissimilarities between the PSAK and the IFRS, a number of differences remain and several IFRS standards and IFRS Interpretations Committee (IFRIC) interpretations do not have SAK equivalents. ${ }^{26}$ These gaps are attributed mainly to the initial development of the PSAK according to the old International Accounting Standards and inability to keep pace with updates of these standards. Also, new IFRS have been issued much more rapidly and have been gaining in complexity. ${ }^{27}$

\section{State-Owned Enterprises and Public Service Organizations}

SOEs are required to follow the PSAK. Public service organizations also had to comply with the PSAK until 2016, when they came under the Government Accounting Standards (SAP).

IFRS. IFRS Application around the World: Indonesia. http://www.ifrs.org/Use-around-the-world/Documents/ Jurisdiction-profiles/Indonesia-IFRS-Profile.pdf.

27 World Bank and International Monetary Fund. 2010. Report on the Observance of Standards and Codes (ROSC) for Accounting and Auditing: Indonesia. Updated in April 2011. 


\section{Government Sector Units}

Under Law No. 17 of 2003 on State Finance, the financial statements of the central government and the SNGs must be prepared in accordance with the SAP. The law also mentions the development of government accounting standards by an independent standards committee in cooperation with the State Audit Board (BPK). The Government Accounting Standards Committee (KSAP) is tasked with formulating the SAP. Government sector units must comply with these standards.

The standards were established in 2005 under Government Regulation No. 24 of 2005 and were used that year in the preparation of the central government's financial statements. These standards derive from the International Public Sector Accounting Standards (IPSAS), although, instead of straightforward adoption of the IPSAS, Indonesia has taken the path of "adoption with modification," adopting the main principles of the IPSAS while considering domestic laws, existing financial practices, and human resource capacity, among other factors. ${ }^{28}$

Several laws mandate the adoption of accrual-based accounting in Indonesia. These laws include Law No. 17 of 2003 on State Finance, Law No. 1 of 2004 on the State Treasury, Law No. 15 of 2004 on the Audit of State Financial Management and Accountability, Law No. 23 of 2014 on Local Government, Government Regulation No. 71 of 2010 on Government Accounting Standards, and Government Regulation No. 58 of 2005 on Regional Financial Management. ${ }^{29}$ Government Regulation No. 71 of 2010 was prepared in accordance with accrual-based IPSAS, but gaps remain, and the government intends to narrow or close these gaps in the long run. The regulation required the central government and the SNGs to apply accrual-based SAP by 2015, after a gradual transition from cash-based standards. The implementation of accrual-based SAP is supervised by the finance minister at the state level, and by the minister of home affairs at the SNG level. Accounting policies and systems are harmonized with accrual-based accounting standards at the central level under Minister of Finance Regulation No. 213 of 2013 on the Accounting and Financial Reporting Systems of the Central Government, Minister of Finance Regulation No. 214 of 2013 on the Chart of Accounts, Minister of Finance Regulation No. 215 of 2013 on the Standard Journal, and Minister of Finance Regulation No. 219 of 2013 on Central Government Accounting Policy. At the regional level, accounting policies and systems are governed under Minister of Home Affairs Regulation No. 64 of 2013 on the Implementation of Accrual Government Accounting Standards at the Regional Government Level, and under regional government regulations on accounting policies. ${ }^{30}$

28 M. Mir and W. Sutiyono. 2013. Public Sector Financial Management Reform: A Case Study of Local Government Agencies in Indonesia. Australasian Accounting, Business and Finance Journal. 7(4). pp. 97-117. http://ro.uow.edu.au/aabfj/vol7/iss4/7.

29 B. H. Simanjuntak. 2016. What Are the Practical Challenges in Implementation of IPSAS? Indonesian Experience. Presentation at the Public Sector Forum 2016 on Financial Reform for Economic Development in Asia. Kuala Lumpur, Malaysia. 17 May 2016. http://www.capa.com.my/images/capa/09_PPT_FRED2_May2016_Breakout1 _BinsarSimanjuntak.pdf.

30 B. H. Simanjuntak. 2016. What Are the Practical Challenges in Implementation of IPSAS? Indonesian Experience. Presentation at the Public Sector Forum 2016 on Financial Reform for Economic Development in Asia. Kuala Lumpur, Malaysia. 17 May 2016. http://www.capa.com.my/images/capa/09_PPT_FRED2_May2016_Breakout1 _BinsarSimanjuntak.pdf. 
There are at present 13 Statements of Government Accounting Standards (PSAP), supported by four Interpretation Statements of Government Accounting Standards and nine Technical Bulletins.

Applicable accrual-based Indonesian government accounting standards are listed in Figure 16 and compared with the IPSAS in Figure 17.

To support the adoption of accrual-based accounting standards, Indonesia has passed new laws and regulations, employed various channels to disseminate the standards and explain their use, and sought the views of accounting professionals and academics. In the process, it has had to contend with various challenges: inadequate training, low availability of public accounting professionals especially in the SNGs, continued use of cash-based budgeting, and nonintegration of various information technology systems.

In 2009, the central government started following an accounting treatment that was close to accrual-based accounting. In 2011, it put in place a computerized accrual accounting system with all supporting ledgers, which continues to be developed and enhanced to include many financial transactions. Government officials at all levels have been trained in accrual-based accounting and reporting to facilitate the use of the system.

The financial statements for 2015 were the first to be based on accrual accounting, following a 10-year transition period. To facilitate the transition, Indonesia maintained parallel systems (of accounting policies, chart of accounts, and information system) starting 2015, in order to prepare financial statements for 2014 on cash toward accrual basis, while recording transactions for 2015 on full accrual basis. The successful transition rested on several key factors: (i) the government's robust implementation and transition strategies, (ii) change management and the commitment and active involvement of shareholders, (iii) PSAP alignment with other regulations and business processes to provide the necessary legal framework, (iv) human resource capacity building through an integrated training program in accrual accounting, and ( $v$ ) an integrated financial management information system with provision for adequate implementation support and guidance. ${ }^{31}$

The phased approach to the implementation of accrual-based Government Accounting Standards, agreed on by the government, Parliament, and the KSAP, is shown in Table 2.32

\section{B. Financial Regulations}

To promote accountability and transparency in the public sector, Indonesia has issued laws, regulations, and technical guidelines related to public financial management in general, and to foreign loans and grants in particular. The laws and government regulations pertaining

\footnotetext{
B. H. Simanjuntak. 2016. What are the Practical Challenges in Implementation of IPSAS? Indonesian Experience. Presentation at the Public Sector Forum 2016 on Financial Reform for Economic Development in Asia. Kuala Lumpur, Malaysia, 17 May 2016. http://www.capa.com.my/images/capa/09_PPT_FRED2_May2016_Breakout1_ BinsarSimanjuntak.pdf.

32 M. Suparman, A. K. Siti-Nabiha, and L. K. Phua. 2015. Public Sector Accounting Reforms: Assessing Indonesia’s Readiness towards Implementing Accrual Accounting. Problems and Perspectives in Management. https://www. researchgate.net/publication/282925934_Public_sector_accounting_reforms_Assessing_Indonesia's_readiness_ towards_implementing_accrual_accounting.
} 


\section{Figure 16: Conceptual Framework of Government Accounting}

\begin{tabular}{|c|c|}
\hline Statement 1: Presentation of Financial Statements & \\
\hline Statement 2: Statement of Budget Realization & \\
\hline Statement 3: Statement of Cash Flows & \\
\hline Statement 4: Notes to the Financial Statements & \\
\hline Statement 5: Accounting for Inventories & \\
\hline Statement 6: Accounting for Investments & \\
\hline Statement 7: Accounting for Fixed Assets & \\
\hline Statement 8: Accounting for Construction in Progress & \\
\hline Statement 9: Accounting for Liabilities & \\
\hline Statement 10: Correction of Errors, Changes in Accounting Policies, and Extraordinary Events & \\
\hline Statement 11: Consolidation of Financial Statements & \\
\hline Statement 12: Statement of Operations & \\
\hline Statement 13: Accounting for Public Service Agencies & \\
\hline
\end{tabular}

Interpretation 1: Transaction in foreign currencies

Interpretation 2: Recognition of revenue received in state, regional, and general cash accounts

Interpretation 3: Recognition of financing transactions received in or disbursed from state, regional,

and general cash accounts

Interpretation 4: Changes in Accounting policies and correction of errors without restatement

\begin{tabular}{|l|l|}
\hline Technical Bulletin 13: Accounting for Grants \\
\hline Technical Bulletin 16: Accounting for Receivables \\
\hline Technical Bulletin 17: Accounting for Intangible Assets \\
\hline Technical Bulletin 20: Accounting for Loss and Indemnification \\
\hline Technical Bulletin 21: Accounting for Liabilities \\
\hline Tecoulletin 18: Accounting for Accrued Depreciation \\
\hline Teccoulletin 22: Accounting for Transfers to Regional Governments \\
\hline Tecounting for Social Assistance \\
\hline
\end{tabular}

Source: Indonesian Government Accounting Standards Committee. 


\section{Figure 17: Comparison of IPSAS and Accrual-Based Indonesian Government Accounting Standards}

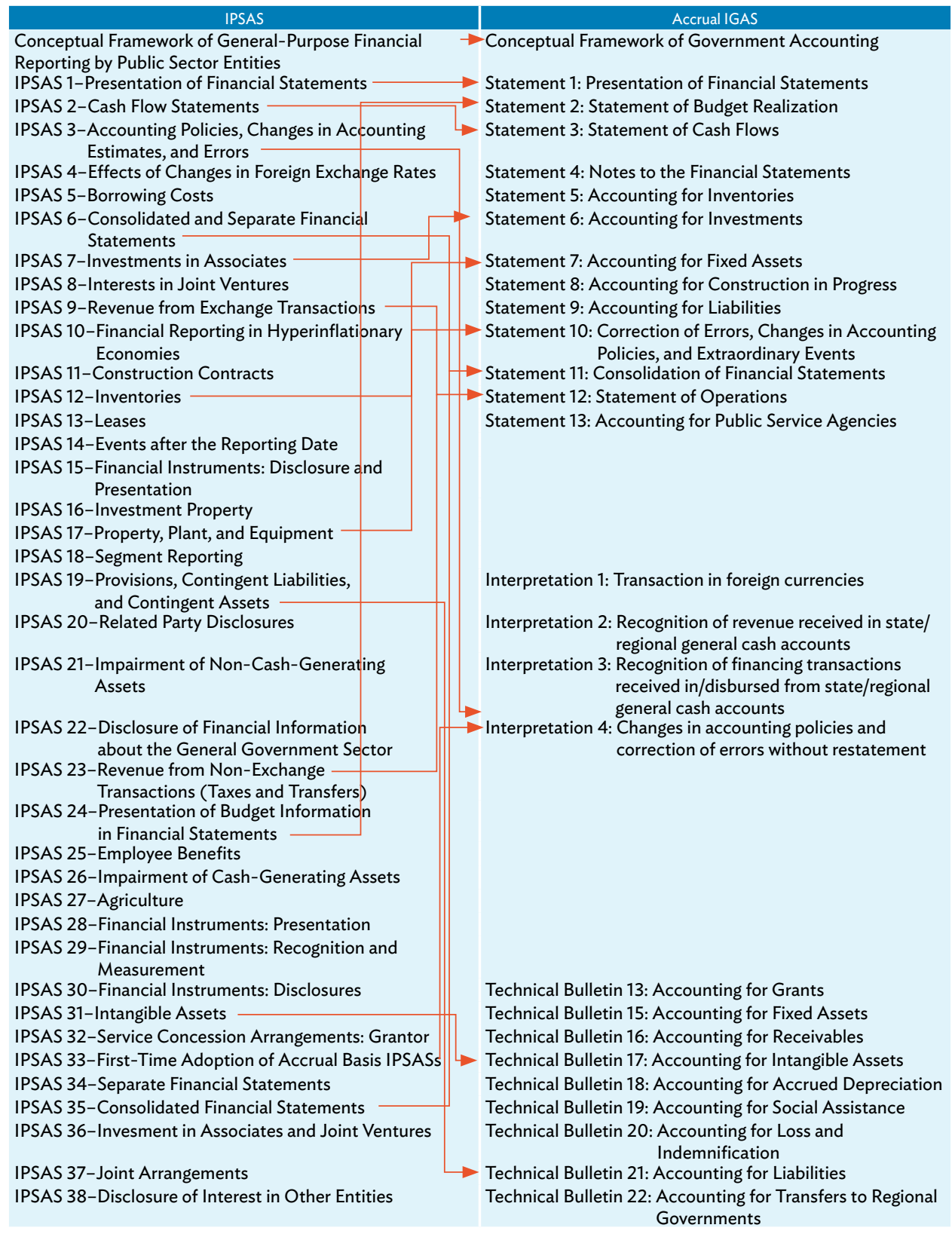

IGAS = Indonesian Government Accounting Standards; IPSAS = International Public Sector Accounting Standards.

Source: B. H. Simanjuntak. 2016. What Are the Practical Challenges in Implementation of IPSAS? Indonesian Experience. Presentation at the Public Sector Forum 2016 on Financial Reform for Economic Development Asia. Kuala Lumpur, Malaysia. 17 May 2016. http://www.capa.com.my/ images/capa/09_PPT_FRED2_May2016_Breakout1_BinsarSimanjuntak.pdf. 


\section{Table 2: Implementation of Accrual-Based Accounting Standards}

\begin{tabular}{|c|c|}
\hline Year & Phase \\
\hline 2010 & $\begin{array}{l}\text { Issuance of accrual-based SAP; development of the framework of accrual-based } \\
\text { accounting; dissemination of the SAP and the framework }\end{array}$ \\
\hline 2011 & Stage I: Technical policy preparation and guidance \\
\hline 2012 & Stage II: Accounting and information technology systems development \\
\hline 2013 & $\begin{array}{l}\text { Stage III: Pilot projects in selected ministries and SOEs; human resource capacity } \\
\text { development }\end{array}$ \\
\hline 2014 & $\begin{array}{l}\text { Parallel run of the systems in all government agencies; systems review, evaluation, and } \\
\text { improvement; human resource capacity development }\end{array}$ \\
\hline 2015 & Full implementation; human resource capacity development \\
\hline \multicolumn{2}{|c|}{ AP = Government Accounting Standards; SOE = state-owned enterprise. } \\
\hline \multicolumn{2}{|c|}{$\begin{array}{l}\text { Source: M. Suparman, A. K. Siti-Nabiha, and L. K. Phua. 2015. Public Sector Accounting Reforms: Assessing } \\
\text { Indonesia's Readiness towards Implementing Accrual Accounting. Problems and Perspectives in Management. } \\
13 \text { (2). https://www.researchgate.net/publication/282925934_Public_sector_accounting_reforms_- } \\
\text { Assessing_Indonesia's_readiness_towards_implementing_accrual_accounting. }\end{array}$} \\
\hline
\end{tabular}

to public financial management apply to both central and regional government. The MOF, as the organization responsible for state financial management, issues further regulations and guidelines that are binding on all ministries and institutions tasked with implementing the state budget. Similarly, the MOHA, as the organization responsible for regional financial management, issues regulations and guidelines applicable at the regional level.

Key laws and government regulations dealing with accounting and financial reporting include the following: ${ }^{33}$

(i) Law No. 17 of 2003 on State Finance, providing for the preparation of budget accountability reports in line with the SAP;

(ii) Law No. 1 of 2004 on the State Treasury, outlining a variety of financial management functions including the establishment of a treasury single account;

(iii) Law No. 15 of 2004 on the Audit of State Financial Management and Accountability, providing for the audit of all government units;

(iv) Government Regulation No. 8 of 2006 on Government Agencies' Performance and Financial Reporting;

(v) Government Regulation No. 71 of 2010 on Government Accounting Standards; and

(vi) Government Regulation No. 10 of 2011 on Procedures for the Procurement of External Loans and Grants.

The financial management functions of the central government ministries and institutions are administered and coordinated mainly under the following regulations issued by the minister of finance:

33 USAID. 2007. Local Government Financial Management Reform in Indonesia: Challenges and Opportunities. Good Governance. Brief No. 3 (September). 
(i) Minister of Finance Regulation No. 238 of 2011 on General Guidelines for the Government Accounting System;

(ii) Minister of Finance Regulation No. 233 of 2011 on the Amendment to Minister of Finance Regulation No. 171 of 2007 on the Accounting and Financial Reporting Systems of the Central Government;

(iii) Minister of Finance Regulation No. 213 of 2013 on the Accounting and Financial Reporting Systems of the Central Government;

(iv) Minister of Finance Regulation No. 214 of 2013 on the Chart of Accounts;

(v) Minister of Finance Regulation No. 215 of 2013 on the Standard Journal;

(vi) Minister of Finance Regulation No. 219 of 2013 on Accrual Accounting Policies;

(vii) Minister of Finance Regulation No. 177 of 2015 on Guidelines for the Preparation and Submission of the Financial Statements of Ministries/Agencies;

(viii) Minister of Finance Regulation No. 84 of 2015 on Procedures for the Withdrawal of Foreign Loans and Grants; and

(ix) Minister of Finance Regulation No. 181 of 2015 on the Accounting and Financial Reporting of Government Debt.

The financial management functions of the SNGs are administered and coordinated under the following items of legislation: ${ }^{34}$

(i) Regional Financial Administration Manual (MAKUDA) 1981 (now the Regional Financial Administration System [SIKD]);

(ii) Minister of Finance Regulation No. 355 of 2001 on the Accounting System Based on the SAKD Version;

(iii) Minister of Home Affairs Regulation No. 29 of 2002 on Guidelines for Financial Management in Local Government;

(iv) Minister of Home Affairs Regulation No. 13 of 2006 on Regional Financial Management Guidelines;

(v) Minister of Home Affairs Regulation No. 59 of 2007 on the Amendment to Minister of Home Affairs Regulation No. 13 of 2006 on Regional Financial Management Guidelines;

(vi) Government Regulation No. 65 of 2010 on the Accounting and Reporting of Regional Budget Implementation; and

(vii) Minister of Home Affairs Regulation No. 64 of 2013 on Implementation of Accrual Government Accounting Standards at the Regional Government Level.

SOEs are regulated under Law No. 19 of 2003 on State-Owned Enterprises, and are created either as limited liability companies (persero) or as public corporations (perum). The Ministry of State-Owned Enterprises (MSOE) Ministerial Decree No. 100 of 2002 on Corporate Governance provides the basis for the monitoring of SOEs, which includes regular assessments of their financial health against a set of eight standard financial criteria. ${ }^{35}$

Public service organizations are governed under Government Regulation No. 23 of 2005 on the Framework for Public Service Organizations, such as universities, laboratories,

34 M. Mir and W. Sutiyono. 2013. Public Sector Financial Management Reform: A Case Study of Local Government Agencies in Indonesia. Australasian Accounting, Business and Finance Journal. 7(4). pp. 97-117. http://ro.uow.edu.au/aabfj/vol7/iss4/7.

35 World Bank. 2012. Indonesia: Public Expenditure and Financial Accountability. Washington, DC. 
and training institutions. Minister of Finance Decree No. 466/KMK.01/2006 sets out clear requirements, including reporting to the Directorate General of Treasury, which has financial oversight of autonomous government agencies. ${ }^{36}$

\section{Application of Accounting Standards and Regulations}

The application of accounting standards and regulations by government entities varies depending on the type of establishment. In other words, the standards apply differently to (i) ministries and institutions, (ii) SOEs, and (iii) public service organizations. Ministries and institutions prepare cash-based budgets and report financial accountability for the implementation of the state budget (APBN) to the minister of finance, adopting an accrual basis in accordance with the SAP. Ministries and institutions are required to submit monthly financial statements that include a budget realization report, a balance sheet, operating reports, and a statement of changes in equity, which are then reconciled with KPPN data. Midyear and year-end reports, including the notes to the financial statements, must also be submitted to the MOF. Reporting takes place through the computerized financial management information system.

SOEs are required to submit quarterly financial statements to the Ministry of State-Owned Enterprises and the relevant line ministry, and to produce audited financial statements (operating statement and balance sheet) annually in accordance with the PSAK. Public service organizations have greater flexibility than ministries and institutions in their financial management requirements but have clear reporting requirements, including the submission of annual and semiannual financial reports to the MOF as outlined in Minister of Finance Decree No. 466/KMK.01/2006. ${ }^{37}$ Public service organizations reported in accordance with the PSAK until 2016, when they were required to start reporting in accordance with accrual-based SAP.

PMUs of foreign-funded projects are set up as part of the central government or SNG unit, and are required to use government accounting systems and comply with the SAP. Although the government began using accrual-based accounting and reporting procedures in 2015, discussions with a PMU indicated that accrual-based reporting has not yet been adopted for projects in the absence of technical guidelines.

\section{Accounting System}

\section{Basis of Accounting}

Minister of Finance Regulation No. 213 of 2013 outlines the accounting and financial reporting system of the central government and sets out implementation guidelines in an appendix. The regulation requires government financial reports to be in accordance with

World Bank. 2012. Indonesia: Public Expenditure and Financial Accountability. Washington, DC.

World Bank. 2012. Indonesia: Public Expenditure and Financial Accountability. Washington, DC. 
the SAP. The appendix to this regulation states that the reports should be prepared on an accrual basis, while adding that cash-based accounting should continue to be applied in the government financial report should be accrual. It also specifies that cash basis shall remain to be applied in compiling the budget realization report as long as the state budget is compiled using the accrual-based approach..$^{38}$ The accrual-based accounting system adopted in 2015 captures cash-basis information on revenue and expenditure; and accrual information on revenue, expense, assets, liabilities, and equities.

PMUs adopt the accounting systems of the executing and implementing agencies. Therefore, transactions are recorded using the applicable accounting standards from 2015. PMU financial reporting to ADB is on a cash basis at present.

\section{Accounting Documents}

Minister of Finance Regulation No. 213 of 2013 identifies the following primary elements for the application of the accounting and financial reporting systems of ministries and institutions: (i) forms or source documents, (ii) journal, (iii) general ledger, (iv) subsidiary ledger, and ( $v$ ) report. The accounting process begins with the verification of source documents, which occurs at the work unit level where the financial transaction takes place.

Source documents for expenditure transactions for the preparation of financial reports at the work unit level of ministries and institutions are presented in Box 5.

PMUs and implementing agencies are required to maintain proper accounting documents for transactions. Internal guidelines of the BPK identify the following accounting documents to be examined in project audits: (i) statement of cash receipts and payments; (ii) advance accounts and subaccounts; (iii) statement of expenditures; and (iv) accounting policies and explanatory notes.

\section{Chart of Accounts}

Minister of Finance Regulation No. 214 of 2013 provides guidance on the central government chart-of-account. SNGs must also report on the same chart of accounts, but have some flexibility in using different chart-of-account codes during the year. Minister of Home Affairs Regulation No. 59 of 2007, Article 77(12), states that "the list of accounts name and code shall not be used as the fixed reference in formulating the account code since the selection will be based on the objective needs and the local characteristics of the regions." 39

PMUs are part of a government unit and are therefore required to maintain accounts following the government chart of accounts with additional categories as required under the loan agreement. Withdrawal applications from PMUs indicate, among others, the budget code (function, subfunction, unit, program, activity, and type of expenditure) for each withdrawal.

38 Ministry of Finance. Minister of Finance Regulation No. 213 of 2013 on the Accounting and Financial Reporting Systems of the Central Government: Appendix (Implementation Guideline of the Central Government Accounting System and Financial Report). Jakarta.

39 World Bank. 2012. Indonesia: Public Expenditure and Financial Accountability. Washington, DC. 


\section{Box 5: Source Documents of Expenditure}

DIPA, revised DIPA, operating activity guidelines, or other equivalent document

Document supporting realized expenditure, such as: SPP, SPM and SP2D, SP2B-BLU and SP3B-BLU, SPHL and $\mathrm{SP} 2 \mathrm{HL}$, or other equivalent document

Adjustment memorandum on the creation of an adjusting journal entry for the accrual transaction, and an asset journal entry

Document associated with the accounts receivable transaction, such as credit card receipt, accounts receivable summary, or accounts receivable balance listing report

Document related to the inventory transaction, such as inventory card, inventory record book, or inventory report

Document associated with the construction and project (KDP) transaction, such as KDP card or KDP report

Other document for the preparation of the financial report of the state agency/institute, such as BAST, statement of inadvertent omission, statement of disposal or reuse of tangible or intangible asset that has been seriously damaged, LHOF

BAST = Berita Acara Serah Terima (record of transfer of goods or services); DIPA = Daftar Isian Pelaksanaan Anggaran (Budget Authorization Document); KDP = Konstruksi dalam Pengerjaan (construction project management); LHOF = Laporan Hasil Opname Fisik (report of physical examination); SP2B-BLU = Surat Pengesahan Pendapatan dan Belanja Badan Layanan Umum (letter of endorsement of the income and expenditure of public service agencies); SP3B-BLU = Surat Perintah Pengesahan Pendapatan dan Belanja Badan Layanan Umum (instrument of approval of the income and expenditure of public service agencies); SP2D = Surat Perintah Pencairan Dana (payment voucher); SPHL = Surat Pengesahan Hibah Langsung (direct grant approval letter); SP2HL = Surat Perintah Pengesahan Hibah Langsung (confirmation of direct grant); SPM = Surat Perintah Membayar (payment order); SPP = Surat Permintaan Pembayaran (money order).

Source: Minister of Finance Regulation No. 213 of 2013 on the Accounting and Financial Reporting Systems of the Central Government (adapted).

\section{Accounting Method}

The government uses a double-entry accounting system based on the accounting equation of assets with liabilities and owner's equity. However, accounting for budgeting purposes is to be carried out on a single-entry basis. ${ }^{40}$

Projects are required to maintain accounting records in accordance with accepted accounting principles, and to adopt cash-based accounting procedures. From 2016 onward, projects must maintain books and records using double-entry accounting.

\section{Computerized Accounting System and Level of Automation}

The Financial Management Information System (SPAN) is the real-time computerized accounting and reporting system of the central government. This systems application of

40 Ministry of Finance. Minister of Finance Regulation No. 213 of 2013 on the Accounting and Financial Reporting Systems of the Central Government-Appendix: Implementation Guideline of the Central Government Accounting System and Financial Report. Jakarta. 
the MOF supports budget execution and treasury management, while providing access for processing financial information by connecting line ministries and institutes that use Treasury resources. The system was first developed in 2009 and was pilot-tested in 2014. As of November 2015, the system was being used by the MOF at Directorate General of Budget Financing and Risk Management and Directorate General of Treasury headquarters, including 182 local KPPNs and 33 regional Treasury offices (kanwils) around Indonesia with more than 3,600 users and serving 24,000 spending units. ${ }^{41}$

SPAN automates critical accounting processes, such as accounts payable, accounts receivable, cash management, government receipts, accounting, general ledger, and commitment control, while providing for comprehensive and timely information on the government's financial position.

Indonesia developed SPAN and some other systems to facilitate the implementation of accrual accounting, but these have not yet been fully integrated in all lines of government. In addition to SPAN developed by the MOF, other systems include the Local Government Financial Management Information System (SIKPD) of the MOHA and the Local Management Information System (SIMDA) of the BPKP, for SNGs. ${ }^{42}$ Line ministries use SAIBA, an accrual accounting system, which is compatible with SPAN.

PMUs use their own accounting programs for recording accounting information. They also have access to a system application for payment orders (SPM), which, however, is not integrated online at the PMU level. Payment orders are currently submitted by PMUs as Excel files to the Treasury office and are physically carried or e-mailed for integration with SPAN for payment processing. PMUs have viewing access to SPAN to allow them to check the list of payments made.

\section{E. Responsible Units}

\section{Accounting Units}

Under Minister of Finance Regulation No. 213, the accounting and financial reporting apparatus of state ministries and institutions is implemented through decentralized accounting units established at different levels.

To ensure the smooth implementation of the accounting process, state ministries and institutions are required to create the agency's accounting units for financial and property reporting according to the organizational hierarchy. State ministries and institutions establish these units at the level of the working unit (including regional working units), regional office, echelon 1, and state ministries and institutions. Financial transactions occur primarily at the working unit level, while accounting and reporting units at the higher level are assigned to combine the financial report from the accounting and reporting units below them.

World Bank. 2015. Indonesia: Centralized Database of Government Financial Transactions Improves Budget Spending and Accountability. Press release. 11 November 2015. Washington, DC.

42 Research Gate. 2015. Problems and Perspectives in Management: Public Sector Accounting Reforms-Assessing Indonesia's Readiness towards Implementing Accrual Accounting. Online article. January. 
The establishment of all these accounting and reporting units does not apply to every single ministry or institution but can be adjusted to suit the characteristics of the state ministry or institution, especially in relation to the organization structure of the entity.

The accounting units process data related to financial transactions, property, and other transactions using an integrated application system to produce the financial report and property reports of the state ministries and institutions.

With regard to projects, PMUs have an accounting unit with an accountant, while PIUs generally have an accounts assistant in charge of the accounting process at the PIU level.

\section{Accounting Staff}

Law No. 1 of 2004 on the State Treasury assigns responsibility for the financial management of the state ministries and relevant institutions to the minister or head of the institution. Accounting staff below echelon 2, as well as accountants at PMUs and account assistants at PIUs, need only Norma Pemeriksaan Akuntan (NPA) certification. However, finding qualified accounting staff to work in SNGs is generally a challenge.

The scarcity of professional accounting skills in SNGs is compounded by difficulties in recruitment and lack of clarity in job analysis. The implementation of accrual-based accounting at the regional level is affected. ${ }^{43}$

\section{F. Fiscal Year}

Law No. 17 of 2003 on State Finance defines the fiscal year of the Government of Indonesia as coinciding with the calendar year, from 1 January to 31 December. The financial year of ADB-funded projects is generally in line with the government's fiscal year.

\section{G. Project Financial Statements}

\section{Preparation of Financial Statements}

Project executing agencies are required to submit financial statements to ADB and relevant government agencies. Project financial statements must conform to the SAP, which is on a cash basis at present. The move to full accrual accounting is expected to be completed by 2017. Project financial statements are prepared yearly by the project accountant at the $\mathrm{PMU}$ and signed off on by the project director and the secretary of the executing agency.

\section{Format of Financial Statements to Be Submitted to Government Agencies}

Government Regulation PP No. 2 of 2006 on foreign grants and loans, revised by PP No. 10 of 2011, states that all development partner-funded projects (implemented by the

43 ResearchGate. 2015. Problems and Perspectives in Management: Public Sector Accounting Reforms-Assessing Indonesia's Readiness towards Implementing Accrual Accounting. Online article. January. 
government and development partners) should be included in financial reporting. This regulation is detailed further in PP No. 40 of 2009, which requires all development partners to use the government's financial reporting format. Each line ministry is responsible for recording and reporting expenditures financed by development partner-executed grants. Ministries and institutions report their expenditures through the Treasury system alongside other expenditures. The Directorate General of Debt Management (now the Directorate General of Budget Financing and Risk Management) is responsible for reporting only on the revenue side. ${ }^{44}$

Each work unit (PIU) reports project expenditure every 6 months to the accounting unit above it, through the government accounting system. The balance sheets, operating reports, and cash flow statements submitted are consolidated by the accounting and reporting unit at the ministry or institute for inclusion in the financial statement of the central government.

\section{Submission of Financial Statements}

Project financial statements must be submitted to the donor as provided in the loan agreement. Audited project financial statements are sent by the auditor to the relevant line ministry, which forwards these to ADB.

\section{Deadline for Submission of Financial Statements}

Deadlines for the submission of audited project financial statements to ADB - generally 6 months after the end of the financial period-are mentioned in the loan agreement. PMUs must submit their statements to the auditor general's department within 3 months from the end of the financial year, and the auditor is expected to submit the audited report within 2 months of receipt of the statement. ADB coordinates a meeting with the representatives of all ADB-funded projects by the end of January or early February, to get them to commit to a date for the submission of their unaudited financial report for audit.

World Bank. 2012. Indonesia: Public Expenditure and Financial Accountability. Washington, DC. 


\section{Auditing Arrangements}

T he Audit Board of the Republic of Indonesia (BPK) is mandated under Article 23E of the Constitution to act as the supreme audit board in investigating the management of state finances and accountability for them. BPK functions obtain further legal authority under (i) Law No. 17 of 2003 on State Finance, (ii) Law No. 1 of 2004 on the State Treasury, (iii) Law No. 15 of 2004 on the Audit of State Financial Management and Responsibility, and (iv) Law No. 15 of 2006 on the Audit Board of the Republic of Indonesia. The BPK's mandate covers the central government, SNGs, other state institutions, Bank Indonesia, SOEs, public service agencies, regionally owned enterprises and institutions, and other entities that manage state finances. More than 3,000 institutions fall within the BPK mandate for annual financial audits. ${ }^{45}$

Annual audit plans are integrated with the budget preparation process and approved by the State Finance Accountability Committee, which is a parliamentary review committee. Audit planning takes a 2-year perspective and applies the audit universe concept to entities. BPK auditors use risk analysis in planning all types of audits. ${ }^{46}$

Law No. 15 of 2004 on the Audit of State Financial Management and Responsibility provides the BPK with independence in audit planning, execution, and reporting of audit findings. The BPK's duties and operations are guided by Audit Board Regulation No. 1 of 2007, the State Financial Audit Standards (SPKN), which comply with international auditing standards. ${ }^{47}$ Aimed at setting the quality benchmark for auditors investigating state financial management and accountability, the standards define the professional requirements for auditors, audit quality, and audit reporting. The BPK also follows its audit management guidelines (PMP), which detail the procedures involved in audit planning, execution, reporting, and monitoring and evaluation. Apart from the SPKN and the PMP, the BPK from time to time releases manuals and guidelines for its auditors to help them comply with legal requirements and professional standards.

The BPK conducts financial audits, performance audits, and special-purpose audits. The audit of financial statements considers compliance with the SAP, adequacy of disclosure, compliance with legislation, and effectiveness of internal controls. ${ }^{48}$ The topics dealt with in performance audits are usually suggested by units or board members, and the final list is

5 Supreme Audit Office of Poland. 2014. Peer Review Report on the Supreme Audit Board of the Republic of Indonesia. Jakarta.

46 Supreme Audit Office of Poland. 2014. Peer Review Report on the Supreme Audit Board of the Republic of Indonesia. Jakarta. 
a board decision. Special-purpose audits could be triggered by a request from Parliament, government, or law enforcement agencies, or conducted at the BPK's own initiative. ${ }^{49}$ Every year, the BPK carries out more than 1,000 audits, about $55 \%$ of which are financial audits, $30 \%$ are performance audits, and $15 \%$ are special-purpose audits. Information technology audits by the BPK are still at a preliminary level and are treated as support for the financial audits. ${ }^{50}$ Under Law No. 15 of 2006, registered public accountants can be appointed to audit ministries and agencies. These accountants are appointed by Parliament at the recommendation of the BPK and the MOF. All audit reports of public accountants are to be submitted to the BPK.

The BPK's audit reports are submitted twice a year to the House of Representatives (DPR), the Regional Representative Council (DPD), and the Regional House of Representatives (DPRD), in accordance with their authority level. Any criminal element found during the audits is reported to the appropriate authorities for further action. The audit reports are to be submitted within 2 months from the receipt of the auditees' response ${ }^{51}$ and executive summaries are published on the BPK's official website..$^{52}$ Around 600 audit reports are submitted to Parliament every semester. In previous years, most of the audit reports for ministries and agencies carried unqualified opinions. Financial statements that received unqualified opinions numbered 69 in 2012, 65 in 2013, and 62 in 2014. Those that were issued qualified opinions totaled 22,19 , and 18 in the same 3 years. Fewer than 10 disclaimers of opinion were issued for ministries and agencies during the period..$^{53}$ The audit opinion on the state accounts has been improving over time. A qualified opinion was received in 2009, after the disclaimers of opinion in the previous 5 years, and an unqualified opinion was obtained in 2013.

\section{A. Auditing Requirements}

Foreign funds are part of state finances included in the national budget and thus are subject to BPK audit. The International Organization of Supreme Audit Institutions (INTOSAI) also mandates the audit of foreign funds by the supreme audit institution of the country. The financial statements of foreign-funded projects have been audited by the BPK since 2011. The BPKP conducted project audits in the past, as agreed on by the government and donors, and still audits projects for which loan agreements were signed before 2011. At present, nine ADB-funded projects and six World Bank-funded projects are audited by the BPK.

ADB's loan agreement requires the audit of project financial statements from executing agencies by an independent auditor acceptable to ADB. The BPK is an acceptable external auditor for ADB-funded projects in Indonesia. State audit standards (SPKN) are also followed in project audits. The audit requirements for foreign-funded projects are governed

\footnotetext{
Supreme Audit Office of Poland. 2014. Peer Review Report on the Supreme Audit Board of the Republic of Indonesia. Jakarta.

50 Supreme Audit Office of Poland. 2014. Peer Review Report on the Supreme Audit Board of the Republic of Indonesia. Jakarta.

51 Law No. 15 of 2004 on the Audit of State Financial Management and Responsibility.

52 Supreme Audit Board of the Republic of Indonesia (BPK). http://www.bpk.go.id/ihps.

53 Ministry of Finance. 2015. Annual Report, 2014. Jakarta.
} 
by the loan or grant agreement and the standard terms of reference (TOR) for the audit of ADB projects, as agreed on by the government and ADB. The TOR for the audit explains the objective and scope of project audits. The agreed standard TOR is in Appendix 1.

The BPK, through the Guide for Audit of Foreign Loans and Grants 2014, provides guidance for auditors in (i) planning the financial audit of foreign-funded projects; (ii) carrying out the audits and gathering evidence; and (iii) providing audit opinions. The executing agencies are required to prepare the project financial statements according to accounting principles acceptable to ADB. The audit of project financial statements generally comprises an examination of (i) the statement of cash receipts and payments for the period; (ii) the advance account(s) and subaccount(s); (iii) the statement of expenditures; (iv) other supplementary schedules of value; and (v) accounting policies and explanatory notes. The audit can also entail a comparison of budget and actual amounts, either as a separate additional financial statement or as a budget column in the statement of cash receipts and payments (applicable when the entity makes its approved budget publicly available). ${ }^{54}$

The audit of foreign-funded projects covers the following: ${ }^{55}$

(i) Fairness of cash flow from foreign loans and grants (PHLN).

(ii) Fairness of $\mathrm{PHLN}$ project financial statements relative to the internal controls of projects and the risk of financial irregularities (fraud).

(iii) Compliance relative to the following:

(a) External funds are being used in accordance with the conditions stated in the associated financing agreement, or in accordance with the purpose of the financing.

(b) Matching funds (if any) have been provided and used in accordance with the related financing agreement, or in accordance with its objectives.

(c) Goods, works, and services financed comply with the related financing agreement, including specific provisions regarding ADB's procurement policies and procedures, and expenditures charged to the project are eligible expenditures, supported by documentary evidence and classified correctly in accordance with the related financing agreements.

(d) All the necessary supporting documents, records, and accounts have been stored in accordance with all project activities, with expenditures reported in the statement of expenditure or the unaudited interim financial report. The audit is expected to verify consistency between the reports issued during the period and the books of account in question.

(e) A clear link exists between the accounting records, including the books of account and the financial reports prepared for the project.

(f) If the special account (advance account) has been used, the examiner must review account activity for special project accounts to ensure compliance with the relevant provisions of the financing agreement. Activities to be

54 Supreme Audit Board of the Republic of Indonesia (BPK). 2014. Draft TOR for Auditing Nonrevenue Earning Executing Agency. 9 June 2014. Jakarta.

55 Supreme Audit Board of the Republic of Indonesia (BPK). 2014. BPK Guide for Audit of Foreign Loans and Grants. Jakarta. 
examined include advance payments received, payments made, interest earned, and reconciliation of balances at the end of the period.

(g) The interim financial report is used as a basis for the filing of the withdrawal application, which should accurately reflect the expenditures and activities during the project period.

(h) Project expenditures reported by project implementing agencies are reconciled with the amounts drawn from the special account (advance account), and amounts deposited to the special account, with the sum of funding from foreign loans and grants (PHLN).

(iv) Compliance with procurement procedures set out in the operations manual and the Presidential Regulation on the Procurement of Goods and Services by the Government. The examiner needs to give special attention to the procurement of consultants and ensure that the deliverables are in accordance with the provisions agreed on with ADB. The examiner will have to verify and review the activities of these consultants.

(v) Contractors' or consultants' compliance with contract management and implementation requirements, to ensure the verification of all project input and output, which must be consistent with the contract provisions.

(vi) Reconciliation of project expenditures from the special account (advance account) with withdrawals from the special account, for prefinancing and direct payments (if any).

Foreign-funded projects are audited following risk-based selection. The BPK conducts risk-based audits for projects and the audit findings have generally pertained to material misstatements, internal control weaknesses, and noncompliance with legislation. These audits are conducted separately from or along with the audit of executing agencies; however, audit opinions for the projects are provided separately. Generally, financial statements are submitted to the BPK within 3 months ${ }^{56}$ after the end of the financial year and the audit reports are issued within the next 2 months. ${ }^{57}$ Several difficulties faced by the BPK in these audits have been pointed out. The overlap in audit timelines for projects and for ministries and agencies creates resource constraints. Procurement presents another difficulty for project auditors. Projects follow donor guidelines, which may at times differ from the government's procurement guidelines. Issues may arise especially when auditors are new to project audits, as opinions may differ regarding the need to use donor guidelines over government guidelines. Better coordination between the donor, the executing agency, and the BPK in disseminating the rationale for procurement may help address this issue.

The audit reports are submitted to the executing agency, which is required to forward these to the donor according to the timelines specified in the TOR or the loan and grant agreements.

Government Regulation No. 8 of 2006 on Government Agencies' Performance and Financial Reporting. Law No. 15 of 2004 on the Audit of State Finance Management and Accountability. 


\section{B. Resolution of Problems Raised in External Audit Reports}

\section{Resolution by ADB}

In accordance with the standard terms of reference for ADB project audits, the BPK is required to submit the audited annual financial statements for a project, together with the corresponding audit report, to the executing agency. The audit report should at least cover the following:

(i) the purpose of the report and its intended use;

(ii) a statement regarding whether the financial statements comply with the SAP, indicating the effect of any deviations from those standards;

(iii) a statement regarding audit compliance with the State Financial Audit Standards (SPKN);

(iv) an audit opinion covering both the current period and the cumulative period since the start of the project;

(v) an audit opinion stating whether or not the financial statements present fairly the statement of expenditures and the advance accounts and subaccounts of the project;

(vi) opinions on compliance with the terms and conditions of the relevant loan or grant agreement, as well as the budget implementation regulations;

(vii) the extent of any noncompliance with the financial covenants; and

(viii) an indication of whether any attached supplementary financial statements and related notes were subjected to the same auditing procedures applied to the basic financial statements.

In addition, the auditor is required to provide specific additional audit opinions on (i) the use of loan or grant proceeds, government funds, and other financing; (ii) compliance with the financial covenants included in the loan or grant agreement; (iii) compliance with project account procedures (where applicable), stating whether or not the advance account (and subaccounts) gives a true and fair picture of the receipts collected and payments made and supports advance account and subaccount liquidations and replenishments during the year; and (iv) compliance with statement-of-expenditure procedures (where applicable), stating whether or not adequate supporting documentation has consistently been provided to support claims for $A D B$ reimbursement of expenditures incurred, and whether or not the expenditures are eligible for financing under the loan or grant agreement. ${ }^{58}$

Any irregularities and instances of noncompliance with government or institutional rules and regulations that do not give rise to a qualified opinion or disclaimer of opinion should be included in the management letter. This report, to be submitted along with the audit report and the opinions on project financial statements (explained in the previous paragraph), contains the following: ${ }^{59}$

58 Supreme Audit Board of the Republic of Indonesia (BPK). 2014. Draft TOR for Auditing Nonrevenue Earning Executing Agency. 9 June 2014. Jakarta. Please refer to ADB's Technical Guidance Note on Project Financial Reporting and Auditing (2015) for updated requirements.

59 Supreme Audit Board of the Republic of Indonesia (BPK). 2014. Draft TOR for Auditing Nonrevenue Earning Executing Agency. 9 June 2014. Jakarta. 
(i) a general overview of the internal control systems of the project and the executing agency, or an opinion on the management systems;

(ii) an identification of material deficiencies or weaknesses in the project's or the executing or implementing agency's internal controls over financial reporting or in the overall system of internal control;

(iii) the auditor's recommendations for improving or rectifying identified weaknesses; and

(iv) follow-up action(s) or the status of previously identified issues and findings, if any.

The executing agency is responsible for implementing the BPK's recommendations and for responding to any queries raised by the auditor. $A D B$ follows up with the executing agency within 6 weeks of receiving the audit reports. A follow-up report with actions taken is submitted to the BPK and ADB by the executing agency.

\section{Resolution by the Government}

The BPK monitors the follow-up actions taken by the executing agency. The Parliament is informed about progress and difficulties in the implementation of BPK recommendations through periodic reports. The large number of auditees makes it difficult for the BPK to monitor regularly the implementation of recommendations. The BPK must increase its capacity for follow-up monitoring. ${ }^{60}$

The State Finance Accountability Committee, established by the DPR under Law No. 27 of 2009, is responsible for evaluating and following up all the audit results submitted by the BPK. The committee submits the review results to the parliamentary commissions for discussion, with its recommendations for follow-up audits by the BPK. ${ }^{61}$

Supreme Audit Office of Poland. 2014. Peer Review Report on the Supreme Audit Board of the Republic of Indonesia. Jakarta.

61 Law No. 27 of 2009 on People's Consultative Assembly, Parliament, Regional Representative Council and Regional Parliament. 


\section{Summary of Risks and Issues, and Proposed Mitigating Actions and Improvements}

$T^{\mathrm{a}}$

able 3 is a summary of risks and issues in country financial management that may affect

project implementation. These risks and issues should be considered by project officers and mission leaders when designing financial management arrangements and conducting financial management and risk assessments.

\section{Table 3: Common Issues, Problems, and Suggestions for Mitigating or Avoiding Risk}

\begin{tabular}{|c|c|}
\hline Observation & Recommendation \\
\hline $\begin{array}{l}\text { Accrual Accounting } \\
\text { The government adopted full accrual accounting } \\
\text { in } 2015 \text {. Project financial statements submitted to } \\
\text { ADB, however, are still prepared on a cash basis. }\end{array}$ & $\begin{array}{l}\text { (For } \mathrm{ADB} \text { ) Determine whether the projects are } \\
\text { geared to the adoption of accrual-based accounting } \\
\text { in preparation for the submission of financial } \\
\text { statements that are acceptable to ADB. }\end{array}$ \\
\hline
\end{tabular}

\section{Accounting Systems}

Indonesia has developed SPAN, SIKPD,

SIMDA, and SAIBA systems to facilitate the implementation of accrual accounting, but these have not yet been fully integrated in all lines of government. Meanwhile, Sakti is used as a conversion program to facilitate accrual reporting.

\section{Internal Audit}

The quality of audit by inspectors general in line ministries and SNG inspectorates needs strengthening to focus on risk-based audit.

Coordination among the internal control systems of regional agencies is weak. No uniform audit planning framework is in place.

\section{External Audit}

The BPPK is mandated under the Constitution to conduct external audits of public sector entities. However, external audits of some projects (for loans signed before 2011) are still being carried out by the BPKP.

The overlap in audit timelines for projects and for ministries and agencies creates resource constraints.

(For ADB) Consider the level of adoption of these systems during project processing and administration.
(For the line ministries and SNG inspectorates) Enhance the capacity of internal auditors through formal education and a professional certification program; pursue collaboration between the BPKP and the inspectorate general to improve the quality of audits through knowledge sharing.

(For ADB) Consider conducting all project external audits only through the BPK.

(For the BPK) Explore outsourcing options for project audits. 
Table 3 continued

\section{Results-Based Lending}

PFM planning, recording, reporting, and monitoring in Indonesia do not cater directly to $\mathrm{RBL}$, which is a new instrument in the country.

\section{Direct Lending to SOEs}

Direct lending from foreign donors to SOEs is subject to the provision of sovereign guarantees. These are off-budget items, and are disclosed only as a note to the financial statements. The government is responsible for repaying the direct borrowings of SOEs in default, although there is no budgetary allocation for it.

The government lacks an active mechanism for managing contingent obligations arising from guarantees given to SOEs.
(For $\mathrm{ADB}$ and the relevant line ministries and institutions) Engage in project-by-project discussion, particularly at the start of the partnership, and agree on appropriate financial management arrangements for each project. The government is currently exploring how this modality may be facilitated within the current government systems. Continuous engagement with the government will be required to facilitate the incorporation of RBL within the PFM system of Indonesia.

Clearly define the scope of each RBL and ensure the availability of data for budgeting and reporting.

(For ADB) Consider assisting the government in introducing a mechanism for managing the financial risk arising from guarantees given to SOEs.

ADB = Asian Development Bank; BPK = Badan Pemeriksa Keuangan (Audit Board of the Republic of Indonesia); BPKP = Badan Pengawasan Keuangan dan Pembangunan (Financial and Development Supervisory Board); PFM = public financial management; RBL = results-based lending; $S A I B A=$ Sistem Akuntansi Instansi Basis Akrual (Accrual-Based Government Accounting System); SIKPD = Sistem Informasi Keuangan Pemerintah Daerah (Local Government Financial Management Information System); SIMDA = Sistem Informasi Manajemen Daerah (Local Management Information System); SNG = subnational government; SOE = state-owned enterprise; $S P A N=$ Sistem Perbendaharaan dan Anggaran Negara (Financial Management Information System).

Source: Author. 


\section{Appendix 1}

\section{Agreed Standard Terms \\ of Reference for the Audit of ADB Projects}

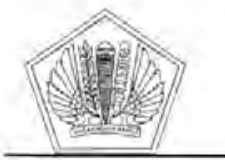

MINISTRY OF FINANCE OF THE REPUBLIC OF INDONESIA DIRECTORATE GENERAL OF DEBT MANAGEMENT DIRECTORATE OF LOANS AND GRANTS

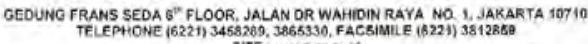
SITE wuw onto or id
No: $\mathrm{S}-561$ /PU. $2 / 2014$

Mr. Edimon Ginting

Oificer-in-Charge IRM-ADB

Gedung BRI II, $7^{\text {th }}$ Floor

Jl. Jend. Sudiman Kav: 44-46

Jakarta 10210
July 18,2014

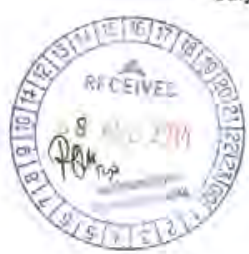

Re. : Draft of Terms of Reference for Audit of ADB Funded Projects - Request for No Objection

Dear Mr. Ginting

Referring to your letter Ref. No. 35/FMDU/07,14 dated 4 July 2014 concerning the above mentioned subject, we would like to inform you that we have no objection with the proposed Terms of Reference. In this regard, please find enclosed our confirmation.

Thank you for your kind altention.

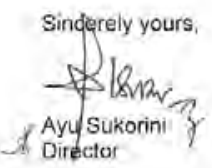

cc.

1. Director General of Debt Management, Ministry of Finance;

2. Secretary General. The Audit Board of the Republic of Indonesia 
Ms. Ayu Sukorini

Director of Loans and Grants

Directorate General of Debt Management

Ministry of Finance

Frans Seda Building, 6th Floor

Ji. Wahidin Raya No. 1

Jakarta, Indonesia

Dear Ms. Sukorini:

\section{Draft of Terms of Reference for Audit of ADB Funded Projects -Request for No Objection}

As part of our Public Communication Policy 2011, the Asian Development Bank (ADB) will post on its website annual project financial statements (APFS). This is for projects whose invitation to negotiate issued by ADB on or after 2 April 2012. For the purpose of this requirement, we also require to have a standardized Terms of Reference (TOR) for audit of ADB funded projects

Following discussions with Badan Pemeriksa Keuangan (BPK), we are pleased to inform you that $A D B$ and BPK have agreed on the standardized TOR as attached. In addition, we also attach BPK's confirmation for your reference.

This letter seeks your no-objection for the attached TOR. We would appreciate receiving confirmation that the Government has no objection to the TOR by countersigning on the space provided herein. Upon your confirmation, the above TOR will be made part of the loan/grant/project agreements for each project

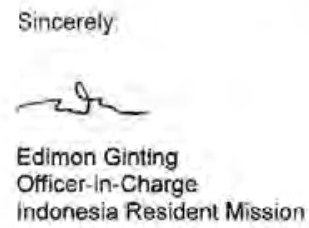

Attachments:

1. Draft of Terms of Reference for Audit of ADB Funded Projects

2. BPK's confirmation on Draft of Terms of Reference for Audit of ADB Funded Projects

cc: Mr. Hendar Ristriawan, Secretary General, Badan Pemeriksa Keuangan RBULN/BNHAFMule

Gedung BRI 11, 7 F Floor, Ill Jend. Sudirman

Kav. 44-45. Jakste 10210 indonesi

Toi +62212512721

$10 x+62212512749$

sabimenodb.org

www ade arg/irm 
We confirm that we have no objection to the Terms of Reference for Audit of ADB Funded Projects

On behalf of the Government of Indonesia

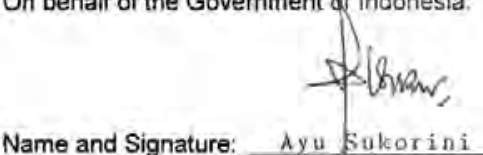

Designation

Director of Loans and Grants.

Date:

July 18,2014 
The Audit Board of the Republic of Indonesia (Badan Pemeriksa Keuengan Republik Indonesia, BPK)

Draft Terms of Reference (TOR)

for Auditing Non-Rovenue Eaming Executing Agency (the Annual Project Financial Statements (APFS) of ADB Funded Projects)

\section{A. The Project}

1. The Project that will be audited, the executing agency (EA). the Project Implementing Units (PIUs) and some audit information are summarized in Annex $1^{2}$

\section{B. Objective of the Audit}

2. The audit of the annual project financial statement (APFS) is primarily designed to ensure that the financial statements (FS) have been prepared in accordance with the relevant legal requirements and accounting standards adopted by the project and give a true and fair view of the financial performance and position of the project.

3. Further, the auditor will provide specific additional audit opinions on:

(i) Use of loan and/or grant proceeds; the Government funds and other financiers.

(ii) Compliance with financial covenants of the loan and/or grant agreements

(iii) Compliance with project account procedures (where applicable) - to confirm or otherwise, whether the imprest account (and sub-accounts) gives a true and fair view of the receipts collected and payments made and supports imprest and sub. account- liquidations and replenishments during the year.

(iv) Compliance with Statement of Expenditure (SOE) procedures (where applicable) - to confirm or otherwise, whether adequate supporting documentation has been maintained to support claims to $A D B$ for reimbursement of expenditures incurred and that the expenditures are eligible for financing under the loan or grant agreement.

In addition, the auditors will provide a report highlighting weaknesses in the internal control system, as stipulated in Para 15

\section{The Conduct of the Audit}

4. The audit will be conducted in accordance with Standard Pemeriksaan Keuangan Negara (SPKN) ${ }^{3}$ and Stendard Professional Akuntan Publik (SPAP, professional standard of public accountant). The standard requires that the auditor plans and performs the audit to obtain reasonable assurance about whether the FS are free from material misstatements. An audit includes examining. on a test basis, evidence supporting the amounts and disclosures in the APFS. An audit also includes assessing the accounting principles used, significant estimates made by the management, as well as evaluating the overall FS presentation.

'The TOR is subject to amendment for any policy changes in ADB or the Government of Indonesia. "Annex 1 will be completed belore Loan Negotiation of the Project

${ }^{3}$ SPKN (Indonosian State Finance Audating Standards) are auditing standards used by BPK as an independent state finance auditor who is responsible to audit all slate linance in Indonesia. 


\section{Audit Procedures}

5. The auditors shall perform audit procedures which include:

(i) Review the Report and Recommendation of the President (RRP) ${ }^{4}$, its linked and supporting documents;

(ii) Plan and conduct the audit in accordance with a risk based framework. The detailed audit work program should be sufficiently extensive in its coverage to support the opinion given:

(iii) Gather sufficient audit evidence to substantiate in all materials respects, the accuracy of information contained in supporting schedules attached to FSs including any and all supporting schedules. This should include verifying samples of transactions and account balances, reviewing any areas where significant estimates and judgments are made by management, as well as performing analysis to verify reported data and confirm year-end balances.

(iv) Review SOEs submitted to ADB in support of requests for periodic replenishments of the project imprest and sub-account ${ }^{5}$. Expenditures should be examined for eligibility based on criteria defined in the terms of financing agreement: Where ineligible expenditures are identified as having been included in withdrawal applications and reimbursed, they should be reported;

(v) Review and evaluate the system of internal control and assess the internal control environment to determine the degree of reliance that may be placed upon them and to determine the extent of testing of actual transactions needed to assure the auditor of the completeness and accuracy of the accounting records:

(vi) Include procedures that are designed to provide reasonable assurance that material misstatements (if any) are detected in accordance with international standards on auditing. The audit coverage will consider the risk of material misstatements as a result of fraud or error.

(vii) Determine whether accounting policies are appropriate and consistently applied, and determine whether all FS disclosures are adequate.

\section{E. Audit Scope in Compliance with Financing Arrangement}

6. To comply with agreed project financing arrangements the auditor shall carry out tests to evaluate the following documents:

(i) The project's imprest account(s) and sub-account(s), if any;

(ii) Statement of Expenditures (SOEs).

(iii) Compliance with covenants contained in the Loan and Grant agreements:

(iv) Any material weaknesses in internal control which are identified duting the audit:

(v) Compliance with Standard Operating Procedures, Financial Management Manual and Procurement Manual,

(vi) Fixed assets procured, review the allocation of project vehicles and equipment and whether these are being utilized in accordance with the ADB's Guidelines and/or Loan and/or Gtant Agreements: and

\footnotetext{
- RRP is an approval report of ADB's Board of Directors related to the loan proposal that had been negotiated between $A D B$ and the Government.

${ }^{5} \mathrm{ADB}$ 's term for the project designaied accounts
} 
(vii) Any other materials which the auditor considers should be bought to the attention of the borrowers/ the Government:

7. Based on the assessment, the auditor shall justify whether,

(1) All funds funded by $A D B$, the Government and other financiers have been used in accordance with the conditions of the relevant loan and/or grant agreements with due attention to econorny and efficiency, and only for the purposes for which the Loan and/or the grant was inlended;

(ii) Counterpart funds and funds from other financiers have been provided and used in accordance with relevant financing agreements, which due attention to economy and efficiency, and only for the purposes for which the loan and/or grant was intended;

(III) Goods, works and services financed, as the procurement plan given in Annex 2 . have been procured in accordance with relevant financing agreements, including specific provisions of the ADB Guidelines and/or Loan and/or Grant Agreements:

(iv) Expenditures submitted to $A D B$ are eligible for financing and all necessary supporting documents, records, and accounts in support of withdrawals have been adequately maintained:

(v) All necessary supporting documents, records, and accounts have been kept in respect of all project expenditures (including expenditures reported using SOEs of imprest Fund Procedures):

(vi) The imprest Accounts and sub-accounts have been maintained and operated in accordance with the provisions of the relevant financing agreements.

\section{F. Annual Project Financial Statements (APFSs):}

B. The auditor should verify whether the APFSs have been prepared in accordance with the Standar Akuntansi Pemerintah (SAP) ${ }^{6}$ and discuss the impact on FSs, if any deviation trom SAP

2. The FSs for the project may include ${ }^{7}$.

(i) A statement of cash receipts and payments for the period:

(ii) Imprest account(s) and sub-account(s):

(iii) Stalement of expenditures (SOEs).

(iv) Other supplementary schedules of value;

(v) Accounting policies and explanatory notes; The explanatory notes should include reconciliation between the amounts shown as "received by the project from ADB " and that disbursed by ADB and a summary of movements on the project's Designated Account; and a comparison of the project budget to accumulated receipts and expenditure (by disbursement categories) since the commencement of the project;

(vi) When the entity makes publicly available its approved budget, a comparison of budget and actual amounts either as a separate additional financial statement or as a budget column in the statement of cash receipts and payments.

- SAP (indonesian Government Accounting Standards) are standards used by the Indonesian EA to prepare its APFSs, which adopted the International Public Sactor Accounting Standands (IPSAS)) This list will be ised as a guldeline. If there are hems that project is not prepaied to provide or cannot provide
BPK will acceot information in whatever lorms that are audilable 


\section{G. Audit Methodology}

10. Based on this TOR, BPK will prepare a methodology to ensure that the audit required is comprehensive and it is expected that a high degree of assurance, compliance with the law and accountability be reflected in the methodology. The methodology should, at minimum, shall address the following.

(i) SPKN Compliance: The auditor should indicate the extent (if any) that the audit would not conform to SPKN and indicate any alternative standards to which the auditors would conform;

(ii) Understanding of the environment and key areas of audit risk for the project:

(iii) Audit planning and the role that the EAVIUs is expected to play in this process:

(iv) The resources to be allocated to the audit to address the risks identified;

(v) The approach to field work (i.e gathering of evidence to support assertions to be made in the audit opinions); and

(vi) Quality assurance arrangements.

\section{H. Audit Report}

12. At minimum, the audit report will:

(i) state the purpose of the report and its intended use;

(ii) state whether SAP have been adopted in the preparation of the APFSs and indicate the effect of any deviations from those standards:

(iii) state that the audit was conducted in accordance with SPKN;

(iv) the audit opinion will cover both the current period and the cumulative period since the commencement of the Project;

(v) the audit opinion will state whether or not the FSs present fairly statement of Expenditures (SOEs), Imprest accounts and sub-accounts of the project,

(vi) The auditor is also expected to express opinions as the compliance with the terms and conditions of the relevant loan or grant agreement as well as the budget execution regulations:

(vii) The auditor should also indicate, where present, the extent of any non. compliance by relerence to the financial covenants:

(viii) The auditor should also indicate whether any attached supplementary FSs and Notes to the FS have been subjected to the same auditing procedures as in the case of the basic FSs.

11. Irregularities and instances of noncompliance with government or institutional rules and regulations that do not give rise to a qualified opinion or disclaimer of opinion should not be subjects of the report of the auditor. When the auditor has comments that are not material to the opinion, these should be set out in the audit report on project's internal control system or statutory regulations.

13. Where the Loan and/or Grant Agreements of a project requires the separate audit of the SOEs and Imprest accounts and sub-accounts, respectively, additional paragraphs should be included in audit opinion as follows:

(i) Referring to the SOE financial statement, certifying to the eligibility of those expenditures against which SOE disbursement were made; and

(ii) Refarring to the imprest account financial statements 
14. At least the following two specific opinions on FS required from the auditor.

(1) Opinion on the statement of expenditures; and

(ii) Opinion of imprest accounts and sub-accounts.

I. Audit Report on The Internal Control System and on Compliance with Statutory Regulations

15. Together with (i) the audit report including the opinion on linancial statements, the auditor will submil (ii) audit report addressing weaknesses in the internal control system and on compliance with statutory regulations that should address as a minimum the following:

(i) a general overview of the internal control systerns of the project and the executing agency, or an opinion on the management systems;

(ii) an identification of material deficiencies or weaknesses in the project of executing/implementing agencies' internal controls over financlal reporting or on the overall system of internal control;

(iii) the auditor's recommendations for improvement or for rectification of identifies weaknesses; and

(iv) Follow-up actions/s or status to previously identified issues and findings, if any.

\section{J. Exit Meeting}

16. Upon the completion of the field work, the auditor will hold an exit meeting with the EA/PIUS. The exit briefing will give the auditor an opportunity to obtain management's comments on the accuracy and completeness of the auditor's findings, conclusions, and recommendations, including whether or not management concurs with the audit findings. It will also include a discussion of common findings across projects being audited and recommendations for addressing bottlenecks in preparation for the next audit. The auditor will document the exit briefing for inclusion in the audit working papers. The EAPIUs could invite the other parties to attend the exit briefing as observers.

\section{K. Access to Information and Records}

15. The auditor will be provided with unrestricted access to all payments records and supporting documents, invoices, and all types of contracts, except claims of consultants engaged directly with ADB including statements of accounts, legal agreements and minutes of meetings, etc. Project staff shall fully cooperate with the auditor. The auditor shall have the rights to access to banks and depositories, consultants, contractors, or other persons or firms engaged by the project In case access has been restricted, the auditor must note this in the auditor's opinion.

16. The auditor is encouraged to meet and discuss audit related matters including inputs to the audit plan with ADB project officers.

17. It is highly desirable that the auditor reviews the Loan and Grant Agreements and their supporting documents, which summarize the ADB's financial reporting and auditing requirements. The auditor should also familiar with the ADB's disbursement and Procurement Handbook. 


\section{Deliverables and Timing}

18. The EAPIU shall prepare the APFS in 2 sets of currency (US\$ dollar and Rupiah). The SOEs in Rupiah and Project Accounts (Pas or Project financial statements in US\$).

19. Two sets of the audited APFSs (in US\$ and in English) and the corresponding audit report (in English) shall be delivered to each EA in accordance with submission dates states in the Loan Agreement(s).

\section{Annexes}

20. All annexes of this TOR will be completed by the EAPIUs and endorsed by ADB prior to the assignment of BPK to conduct the audit of the project. 
Project Background, Executing and Implementing Agencles

Annex 1

A. The Project to be Audited:
1. Project No:
2. Grant No:
3. Project Name:
4. Executing Agency:
5. Implementing Agencies:
6. Total Project Costs:

\section{B. Project Description}

1. Impact, Outcome and inputs: The Project impact will be $x x x x \times x x \times \quad x x x x x x x x \times x x \times x x x$

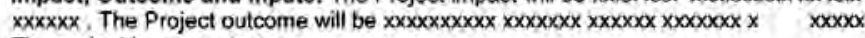
The project has xx outputs.

(i) Output 1: $x \times x \times x$

(ii) Output $2: x x x x$.

(iii) Output 3: $\times \times \times x$

(iv) Output $n: x x x$

\section{Project Areas: $x x x x x x$}

c. The Executing and the implementing Agencies (EA/As):

The Project's organizational structure is given in Annex xx.

$x \times x x \times x x x x x x x x x x$ will serve as the executing agency. The implementing agencies will be : i..

D. Phasing of the Audit:

1. BPK will submit the final audited APFS and supporting documents, as scheduled in the following table:

$$
\text { Month of fiscal year (FY) and report submission }
$$

\begin{tabular}{|c|l|l|l|l|}
\hline Period & FY start & FY End & $\begin{array}{l}\text { Report } \\
\text { Submission }\end{array}$ & Remarks \\
\hline 1 & 1 January 20xx & 31 December 20xx & 30 June 20xx & \\
\hline 2 & 1 Januaty 20xx & 31 December 20xx & 30 June 20xx & \\
\hline 3 & 1 January 20xx & 31 December 20xx & 30 June 20xx & \\
\hline 4 & 1 January 20xx & 31 December 20xx & 30 June 20xx & \\
\hline 5 & 1 January 20xx & 31 December 20xx & 30 June 201xx & \\
\hline
\end{tabular}

Source: the Government, July 2013

2. BPK will automatically be responsible for auditing the Project that will cover for all duration of the project (from the effectiveness date to the closing date of the loan and/or grant). The audit related expenditures will be fully funded by the Government. However, 
BPK-Terms of Raference

9 June 2014

since the Project will cover a wide numbers of project areas, the Project may allocate adequate funds to cover the incremental costs of the auditors to conduct their tasks. 
BPK-Terms of Reference

PROCUREMENT PLAN" g June 2014

Annex 2

'Please present the complete procurement plan of the Project in this Annex 


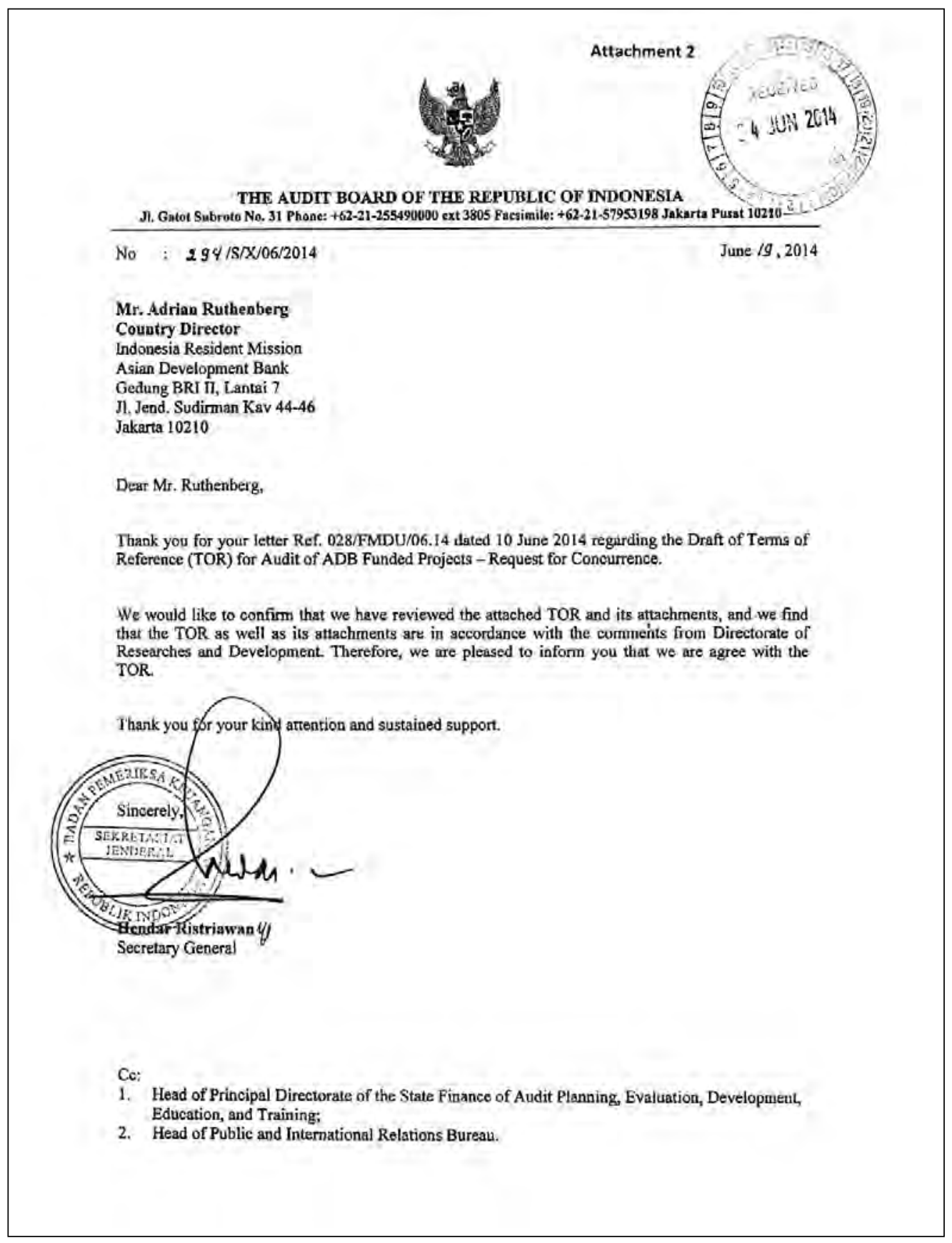




\section{Appendix 2 Useful References and Suggested Readings}

\section{Official Websites of Government Institutions}

1. Audit Board of the Republic of Indonesia (BPK). http://www.bpk.go.id/

2. Bank Indonesia. http://www.bi.go.id/en/Default.aspx

3. Directorate General of Budget. http://www.anggaran.depkeu.go.id/dja/default.asp

4. Directorate General of Budget Financing and Risk Management (DJPPR). http://www.djppr.kemenkeu.go.id/\#/en/page/home

5. Directorate General of Fiscal Balance. http://www.djpk.kemenkeu.go.id/

6. Directorate General of Treasury. http://www.djpbn.kemenkeu.go.id/portal/en/

7. Directorate of Investment Management System (SMI). http://www.djpbn.kemenkeu.go.id/direktorat/smi/

8. Financial and Development Supervisory Board (BPKP). http://www.bpkp.go.id/

9. Ministry of Finance (MOF). http://www.kemenkeu.go.id/en

10. Ministry of Home Affairs (MOHA). http://www.kemendagri.go.id/

11. National Development Planning Agency (BAPPENAS). http://www.bappenas.go.id/id/

\section{Acts, Regulations, and Circulars}

1. The Constitution of the Republic of Indonesia (1945)

2. BAPPENAS Regulation No. 4 of 2011 on Procedures of Planning, Proposing, Assessing, Monitoring, and Evaluating Projects Financed by External Loans and Grants

3. Government Regulation No. 23 of 2005 on the Framework for Public Service Organizations

4. Government Regulation No. 24 of 2005 on Government Accounting Standards

5. Government Regulation No. 58 of 2005 on Regional Financial Management

6. Government Regulation No. 2 of 2006 on Foreign Loans and Grants

7. Government Regulation No. 8 of 2006 on Government Agencies' Performance and Financial Reporting

8. Government Regulation No. 60 of 2008 on Internal Control Systems

9. Government Regulation No. 65 of 2010 on the Accounting and Reporting of Regional Budget Implementation

10. Government Regulation No. 71 of 2010 on Government Accounting Standards

11. Government Regulation No. 90 of 2010 on the Preparation of the Work Plan and Budget for the State, Ministries, and Institutions

12. Government Regulation No. 10 of 2011 on Procedures for the Procurement of External Loans and Grants

13. Law No. 8 of 1995 on the Capital Market

14. Law No. 22 of 1999 on Local Government (replaced by Law No. 23 of 2014) 
15. Law No. 17 of 2003 on State Finance

16. Law No. 19 of 2003 on State-Owned Enterprises

17. Law No. 1 of 2004 on the State Treasury

18. Law No. 15 of 2004 on the Audit of State Finance Management and Accountability

19. Law No. 25 of 2004 on the National Development Planning System

20. Law No. 33 of 2004 on Fiscal Balance between the Central and Regional Governments

21. Law No. 15 of 2006 on the Audit Board of the Republic of Indonesia

22. Law No. 40 of 2007 on Indonesian Company Law

23. Law No. 23 of 2014 on Local Government

24. Minister of Finance Regulation No. 355 of 2001 on Accounting System Based on the SAKD Version

25. Minister of Finance Regulation No. 466/KMK.01/2006 on Assessment of Financial Health Levels of State-Owned Enterprises

26. Minister of Finance Regulation No. 233 of 2011 on Accounting and Financial Reporting of the Central Government

27. Minister of Finance Regulation No. 238 of 2011 on General Guidelines for the Government Accounting System

28. Minister of Finance Regulation No. 249 of 2011 on Performance Measurement and Evaluation of the Implementation of Line Ministries Planning Document for Budget and Activities

29. Minister of Finance Regulation No. 213 of 2013 on the Accounting and Financial Reporting Systems of the Central Government

30. Minister of Finance Regulation No. 214 of 2013 on the Chart of Accounts

31. Minister of Finance Regulation No. 215 of 2013 on the Standard Journal

32. Minister of Finance Regulation No. 219 of 2013 on Accrual Accounting Policies

33. Minister of Finance Regulation No. 136/PMK.02/2014 on Guidelines for the Preparation and Review of the Work Plan and Budget of the State Ministries and Institutions

34. Minister of Finance Regulation No. 84 of 2015 on Procedures for Withdrawal of Foreign Loans and Grants

35. Minister of Finance Regulation No. 127 of 2015 on Budget Classification

36. Minister of Finance Regulation No. 177 of 2015 on Guidelines for Preparation and Submission of Financial Statements of Ministries/Agencies

37. Minister of Finance Regulation No. 181 of 2015 on the Accounting and Financial Reporting of Government Debt

38. Minister of Finance Regulation No. 196/ PMK 02/2015 on Line Ministry Expenditure

39. Minister of Finance Regulation No. 231/PMK 02/2015 on Nonline Ministry Expenditure

40. Minister of Home Affairs Regulation No. 13 of 2006 on Regional Financial Management Guidelines

41. Minister of Home Affairs Regulation No. 59 of 2007 on Regional Financial Management Guidelines

42. Minister of Home Affairs Regulation No. 64 of 2013 on the Implementation of Accrual Government Accounting Standards at the Regional Government Level

43. Minister of State-Owned Enterprises Regulation No. 100 of 2002 on Assessment of Financial Health Levels of State-Owned Enterprises

44. Presidential Regulation No. 192 of 2014 on the Financial Supervision and Development Agency

45. Presidential Regulation No. 11 of 2015 on the Ministry of Home Affairs 


\section{Government Reports and Documents}

1. Audit Board of the Republic of Indonesia (BPK). 2014. Guide for Audit of Foreign Loans and Grants. Jakarta.

2. Audit Board of the Republic of Indonesia (BPK). 2015. Annual Report 2014. Jakarta.

3. Ministry of Finance. 2015. Economic Stability for Prosperity: Annual Report 2014. Jakarta.

\section{Asian Development Bank Resources}

1. ADB. 2015. Report and Recommendation of the President for the Public Financial Management Assessment-Financial Market and Inclusion Program (Subprogram 1). Manila (RRP 48207-002-INO).

2. ADB. 2015. Summary of Indonesia's Public Sector Management Sector Assessment. Papers on Indonesia. No. 11. Manila.

3. ADB. 2017. Loan Disbursement Handbook. Manila.

\section{Other References}

1. Audit Board of the Republic of Indonesia (BPK). 2014. Draft Terms of Reference for Auditing Non-Revenue-Earning Executing Agency. 9 June. Jakarta.

2. B. H. Simanjuntak. 2016. What Are the Practical Challenges in Implementation of IPSAS? Indonesian Experience. Presentation at the Public Sector Forum 2016 on Financial Reform for Economic Development in Asia. Kuala Lumpur, Malaysia. 17 May 2016. http://www.capa.com.my/images/capa/09_PPT_FRED2_May2016_ Breakout1_BinsarSimanjuntak.pdf.

3. IFRS. IFRS Application Around the World: Indonesia. http://www.ifrs.org/Use-around -the-world/Documents/Jurisdiction-profiles/Indonesia-IFRS-Profile.pdf.

4. M. Mir and W. Sutiyono. 2013. Public Sector Financial Management Reform: A Case Study of Local Government Agencies in Indonesia. Australasian Accounting, Business and Finance Journal. 7(4). pp. 97-117. http://ro.uow.edu.au/aabfj/vol7/iss4/7.

5. M. Suparman, A. K. Siti-Nabiha, and L. K. Phua. 2015. Public Sector Accounting Reforms: Assessing Indonesia's Readiness towards Implementing Accrual Accounting. Problems and Perspectives in Management. 13 (2). https://www.researchgate.net/ publication/282925934_Public_sector_accounting_reforms_Assessing _Indonesia's_readiness_towards_implementing_accrual_accounting.

6. Netherlands Court of Audit. 2009. Peer Review of Audit Board of Indonesia.

7. Supreme Audit Office of Poland. 2014. Peer Review Report on the Supreme Audit Board of the Republic of Indonesia. Warsaw.

8. USAID. 2007. Local Government Financial Management Reform in Indonesia: Challenges and Opportunities (Local Governance Support Program (LGSP). Good Governance Brief. No. 3 (September).

9. World Bank. 2007. Indonesia: Public Expenditure and Financial Accountability (PEFA). Washington, DC.

10. World Bank. 2012. Indonesia: Repeat Public Expenditure and Financial Accountability (PEFA) Report and Performance Indicators. Washington, DC.

11. World Bank. 2014. Cash Management Reform in Indonesia: Making the State Money Work Harder. Washington, DC.

12. World Bank. 2014. Indonesia Cash Management Reform. Washington, DC. Page 71. 
13. World Bank. 2015. Indonesia: Centralized Database of Government Financial Transactions Improves Budget Spending and Accountability. Press release. 11 November 2015. Washington, DC.

14. World Bank and International Monetary Fund. 2011. Report on the Observance of Standards and Codes (ROSC) - Indonesia, Accounting and Auditing. Washington, DC. 


\section{Public Financial Management Systems-Indonesia Key Elements from a Financial Management Perspective}

Foreign aid to Indonesia takes the form of loans or grants. The loans can be made either to the government or to state-owned enterprises with a guarantee from the government. This report documents Indonesia's financial management systems covering budgeting, funds flow monitoring and analysis, accounting and reporting, and auditing. It also provides insights into the quality of internal control systems, staff capacity, and information technology structure. The intent is to provide project teams and consultants with a better understanding of financial management systems during project preparation. Find out how high-quality financial management assessments support project implementation through the identification of key risks and enabling the implementation of mitigating actions and reforms.

\section{About the Asian Development Bank}

ADB's vision is an Asia and Pacific region free of poverty. Its mission is to help its developing member countries reduce poverty and improve the quality of life of their people. Despite the region's many successes, it remains home to a large share of the world's poor. ADB is committed to reducing poverty through inclusive economic growth, environmentally sustainable growth, and regional integration.

Based in Manila, ADB is owned by 67 members, including 48 from the region. Its main instruments for helping its developing member countries are policy dialogue, loans, equity investments, guarantees, grants, and technical assistance. 